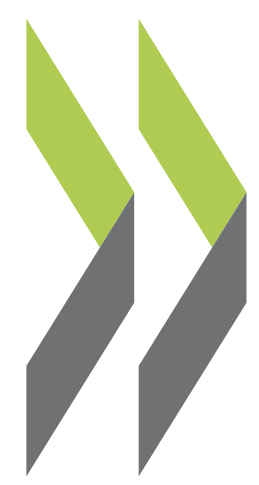

OECD Social, Employment and Migration Working Papers No. 233

\title{
Improving work-based learning in schools
}

\section{Pauline Musset}




\section{DIRECTORATE FOR EMPLOYMENT, LABOUR AND SOCIAL AFFAIRS} EMPLOYMENT, LABOUR AND SOCIAL AFFAIRS COMMITTEE

Cancels \& replaces the same document of 25 September 2019

\section{IMPROVING WORK-BASED LEARNING IN SCHOOLS}

OECD Social, Employment and Migration Working Papers No. 233

Pauline Musset, Policy Analyst, OECD (Pauline.Musset@oecd.org)

Authorised for publication by Stefano Scarpetta, Director, Directorate for Employment, Labour and Social Affairs.

This cancel and replace version of the document is being issued to include the text below in the acknowledgments and the European Union logo on page 2.

This document was produced with the financial assistance of the European Union. The views expressed herein can in no way be taken to reflect the official opinion of the European Union.

All Social, Employment and Migration Working Papers are now available through the OECD website at www.oecd.org/els/workingpapers

JT03464660 


\title{
OECD Social, Employment and Migration Working Papers
}

\author{
www.oecd.org/els/workingpapers
}

OECD Working Papers should not be reported as representing the official views of the OECD or of its member countries. The opinions expressed and arguments employed are those of the author(s).

Working Papers describe preliminary results or research in progress by the author(s) and are published to stimulate discussion on a broad range of issues on which the OECD works. Comments on Working Papers are welcomed, and may be sent to els.contact@oecd.org.

This series is designed to make available to a wider readership selected labour market, social policy and migration studies prepared for use within the OECD. Authorship is usually collective, but principal writers are named. The papers are generally available only in their original language - English or French - with a summary in the other.

This document and any map included herein are without prejudice to the status of or sovereignty over any territory, to the delimitation of international frontiers and boundaries and to the name of any territory, city or area.

The statistical data for Israel are supplied by and under the responsibility of the relevant Israeli authorities. The use of such data by the OECD is without prejudice to the status of the Golan Heights, East Jerusalem and Israeli settlements in the West Bank under the terms of international law.

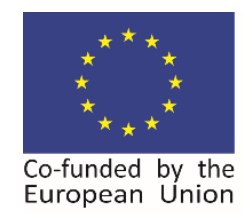

(C) OECD 2019

You can copy, download or print OECD content for your own use, and you can include excerpts from OECD publications, databases and multimedia products in your own documents, presentations, blogs, websites and teaching materials, provided that suitable acknowledgment of OECD as source and copyright owner is given. All requests for commercial use and translation rights should be submitted to rights@,oecd.org. 


\section{Acknowledgements}

The preparation of this working paper was funded by Australia and the European Commission. This paper was drafted by Pauline Musset from the OECD Centre for Skills, with contributions from Simon Field and Edoardo Magalini. Jennifer Cannon prepared the text and steered the paper to publication. Charity Kome provided valuable administrative support. The opinions expressed and arguments employed herein do not necessarily reflect the official views of the OECD member countries.

The OECD would like to thank colleagues in Australia for their constructive engagement in the study. Australian colleagues provided background information, organised a field visit and a workshop, and provided comments on drafts. The OECD also wants to thank the many stakeholders in Australia who shared their perceptions and experiences around WBL in schools. The OECD wants to thank the European Commission for their support, in particular Mantas Sekmokas and colleagues who provided valuable comments on drafts. Sweden organised a workshop and a field visit. The OECD also thank them, as well as officials in other countries who provided answers to the OECD questionnaire that fed into the work. Finally, the OECD would like to thank Hélène Guiol from UNESCO for valuable inputs and support.

Within the OECD, Anthony Mann oversaw the preparation of this report. Benedicte Bergseng, Shinyoung Jeon, Viktoria Kis and Annelore Verhagen provided valuable comments and advice. The project benefited considerably from the support of Cécile Bily. Support throughout the project was received from Montserrat Gomendio as Head of the Centre for Skills, Andreas Schleicher Director of the Directorate for Education and Skills, and Stefano Scarpetta, Director of the Directorate for Employment, Labour and Social Affairs.

This document was produced with the financial assistance of the European Union. The views expressed herein can in no way be taken to reflect the official opinion of the European Union. 


\section{Abstract}

Looking at secondary schools, this paper analyses work-based learning (WBL) as an element of both general education and vocational programmes. The workplace is a powerful learning environment where technical skills can be learnt from expert practitioners using real-life equipment, while also acquiring key soft skills such as teamwork and communication. WBL offers students the opportunity to transition from school to work, while for employers it offers a means of recruitment. However, it can be challenging to engage employers. Quality requires good WBL design and supporting mechanisms. The length and sequencing of WBL are important. The equity risks of WBL also need to be managed. The paper considers different policy messages for schools and jurisdictions.

\section{Résumé}

Le présent document aborde la thématique de l'apprentissage sur le lieu de travail en tant qu'élément des programmes d'enseignement général et professionnel dans les écoles secondaires. Le lieu de travail est un environnement d'apprentissage puissant dans lequel les compétences techniques peuvent être enseignées par des praticiens experts utilisant des équipements réels, et les élèves peuvent acquérir des compétences générales telles que le travail en équipe et la communication. Cet apprentissage offre aux étudiants la possibilité de passer plus facilement de l'école au travail, alors que pour les employeurs, il offre un moyen de recrutement. Cependant, il peut être difficile de faire participer les employeurs. Des mécanismes adéquats d'évaluation de la qualité doivent être mis en place, et les écoles et les employeurs doivent être soutenus. La longueur et le séquencement des stages en entreprise sont importantes. Il existe aussi des risques quant à l'égalité des opportunités, qui doivent être pris en compte. Le document énonce différentes pistes de politiques publiques, pour les écoles et les gouvernements. 


\section{Table of Contents}

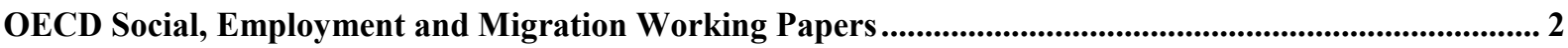

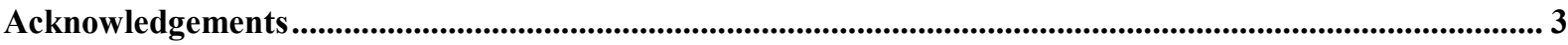

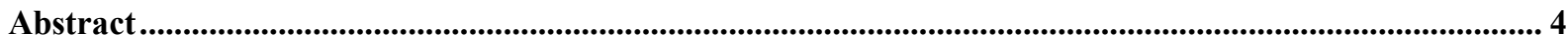

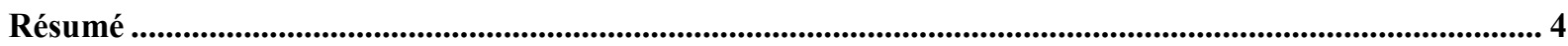

Chapter 1. Why Work-based learning matters and where it fits into education and training ....................... 7

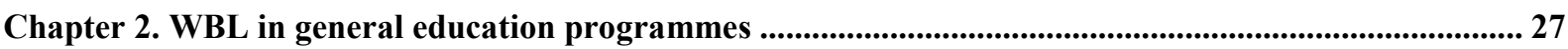

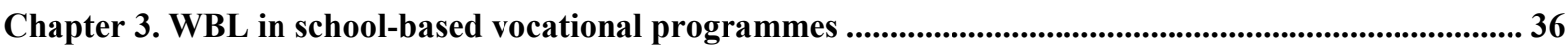

Chapter 4. Realising the benefits of WBL ...............................................................................................................46

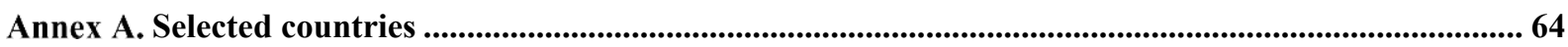

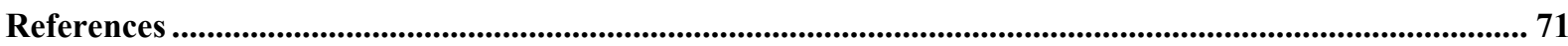

\section{Tables}

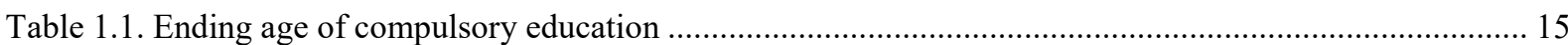

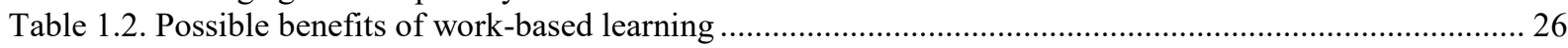

Table 3.1. The use of WBL in school-based vocational programmes in selected countries ............................. 37

Table 3.2. An overview of WBL in VET programmes in Sweden ............................................................ 39

\section{Figures}

Figure 1.1. Many young people do not enter tertiary education ......................................................... 8

Figure 1.2. The division of students between general education and VET varies across countries .................... 10

Figure 1.3. Students are enrolled in different types of programmes ........................................................... 11

Figure 1.4. In many countries, most students finish upper secondary education ........................................... 14

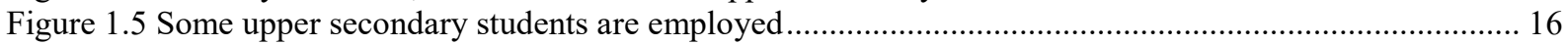

Figure 1.6. In many countries, it is common for graduates to have work experience .................................... 17

Figure 1.7. Graduates with work experience do better in the labour market than those without........................22

Figure 2.1. In general education, students may have access to WBL and/or work ...................................... 29

Figure 2.2. VET students participate more in internships in many countries than students in general education. 30

Figure 2.3. Employers' views on potential young recruits ................................................................. 32

Figure 3.1. Vocational students have exposure to the labour market through multiple forms of WBL …............ 38

Figure 3.2. Vocational graduates enter tertiary programmes in some countries............................................ 41

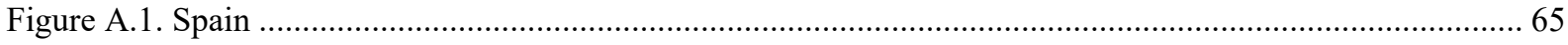

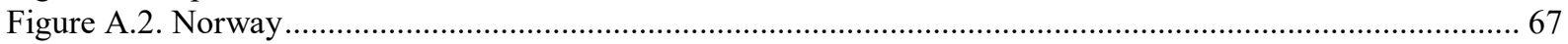

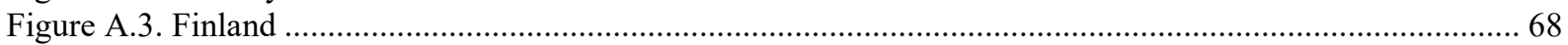

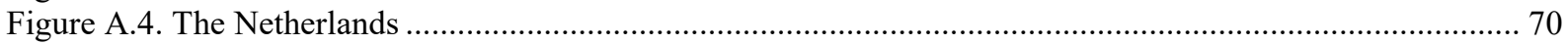

\section{Boxes}

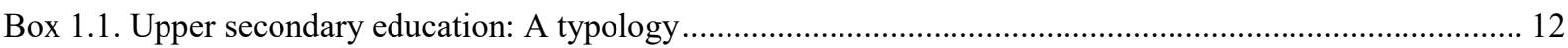

Box 1.2. The EU-LFS ad hoc module on young people in the labour market................................................ 18

Box 2.1. Compulsory WBL in all upper secondary programmes in Italy ..................................................... 28 


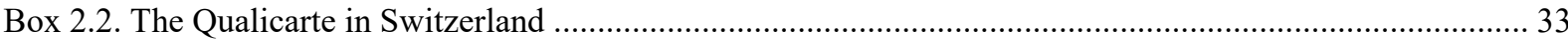

Box 2.3. Summary of the policy messages.......................................................................................... 35

Box 3.1. Countries organise the transition between upper secondary VET and higher education in different ways.....

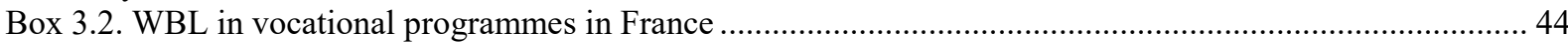

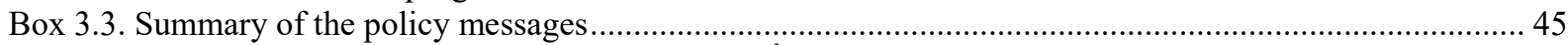

Box 4.1. Increasing the productive benefits of WBL in Świętokrzyskie, Poland.......................................... 47

Box 4.2. Transferring innovative models of work-based learning in Finland ................................................ 49

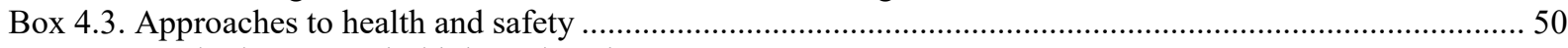

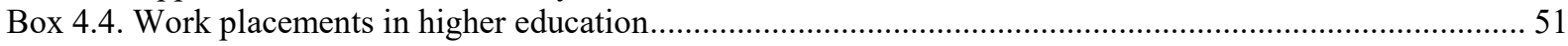

Box 4.5. Innovative approaches using WBL to engage youth at risk in the United States .............................. 54

Box 4.6. Accrediting employers to provide WBL in the Netherlands and in Denmark ....................................56

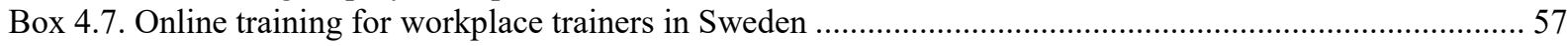

Box 4.8. Encouraging students to reflect on their WBL experience in Austria ............................................59

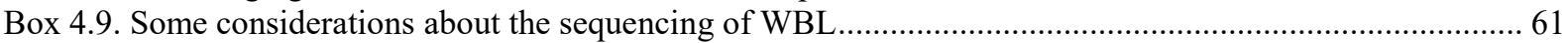

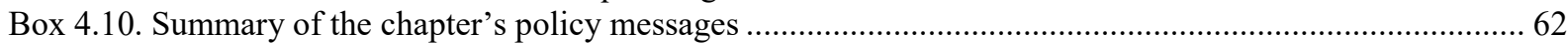




\section{Chapter 1. Why Work-based learning matters and where it fits into education and training}

Chapter 1 introduces the policy paper and describes the focus of this OECD exercise, focusing on work-based learning as part of secondary school programmes. It looks at the many benefits of such learning: the workplace is a powerful learning environment where technical skills can be learnt from expert practitioners using real-life equipment, while also acquiring key soft skills such as teamwork and communication. School-mediated WBL offers students the opportunity to transition from school to work, while for employers it offers a means of recruitment. Student employment also has benefits and ease the transition into employment.

\section{Introduction}

\section{Rationale behind the work}

1. Work-based learning (WBL) is incorporated in upper secondary programmes in different ways, depending on how the education system itself is organised. It is typically incorporated as a substantial component in school-based vocational education programmes. Countries and schools sometimes face availability and quality issues, which means that some students in these pathways are missing out on the significant benefits that comes from learning that takes places in real work environments [see (OECD, 2010 $\left.\left.0_{[1]}\right)\right]$. WBL, especially under the form of short placements, is also a component of general education programmes, usually to allow student to learn about work [see (Musset and Mytna Kurekova, 2018[2])]. In some countries, many upper secondary students work, and their jobs may be unrelated to their study programme (Figure 1.5). In many countries, most students follow a general education programme, but some do not continue into further levels of education after completion of secondary education. This means that they may enter the labour market without having received any type of skills specific to employment. They may not bring with them any direct experience of work. It is estimated that, on average across OECD countries, $44 \%$ of young adults will never enter tertiary education, if current patterns of entry continue (Figure 1.1) and many more students will not finish that level of education. There are concerns from the sponsors of this analytical work that WBL has been overlooked as a form of learning and that students do not engage enough in workplaces whether through their schools or independently. 
Figure 1.1. Many young people do not enter tertiary education

Share of individuals $20-24$ years-old not enrolling in tertiary education (ISCED from 5 to 8 ).

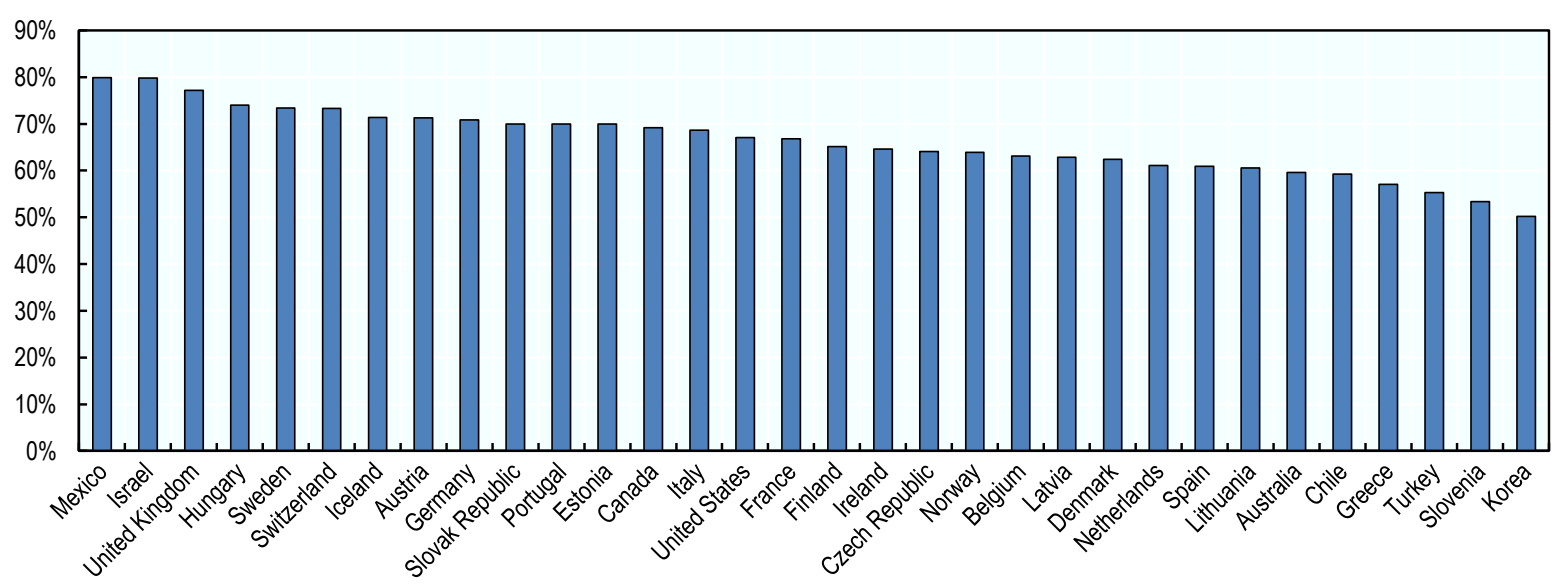

Source: OECD, (2019[3]), OECD.Stat, https://stats.oecd.org.

2. This paper looks at:

- To what extent do secondary school students have experience of work?

- What are the benefits of WBL to learners, employers and to society?

- How do secondary education programmes incorporate school-mediated WBL?

- Which practices and approaches used by countries and schools show promise?

\section{Methodology}

3. The paper focuses on upper secondary schools, and the work leading to its preparation was funded by Australia and the European Commission. The OECD Secretariat prepared a questionnaire, to which a number of jurisdictions responded, with the aim of identifying how programmes in each jurisdiction utilise WBL within secondary education, focusing on vocational programmes. The OECD also held - with the participation of UNESCO - a field visit to Australia on 12-19 November 2018, engaging with practice in Tasmania and the Australian Capital Territory jurisdictions, interviewing policy makers, visiting upper secondary schools and workplaces offering placements for students.

4. The OECD and the Australian Government organised a workshop in Canberra on 19 November 2018. The workshop was attended by over 100 people, a mixture of practitioners (VET teachers, school leaders and training provider representatives), policy makers and other stakeholders (employer representatives and researchers). The event focused on challenges in designing and delivering effective WBL, some of them are highlighted in Chapter 4 of this policy paper. A second workshop was organised in Sweden, jointly by the National Agency for Education and the Ministry of Education and Science, in Stockholm on 25-27 March 2019. This was attended by some 40 people including representatives from different jurisdictions in Australia and several European countries. Its objectives were collecting and sharing innovative practices between participants and therefore included field visits to different types of secondary institutions providing WBL to students. Jurisdictions' experiences in the use of WBL in upper secondary schools were very different and opportunities for peer learning, welcomed. 
5. This paper is organised in four sections exploring:

- Chapter 1 presents the benefits of WBL within the broader framework of upper secondary education.

- Chapter 2 looks at the issues around WBL within general education.

- Chapter 3 focuses on WBL within vocational programmes.

- Chapter 4 identifies some of the common policy issues arising and studies measures to realise the benefits of WBL.

\section{Definitions}

6. Work-based learning (WBL) refers to a set of learning practices that differ from those that are classroom- or school-based. WBL takes place in a real work environment, through participation in, and/or observation of work, under the supervision of an employer (Interagency Group on Technical and Vocational Education and Training, 2016 [4]). Consequently, WBL is a phrase that describes a variety of practice, including the training of people (whether formal, informal or non-formal) that takes place within any workplace. ${ }^{1}$ The paper excludes consideration of programmes in which over $50 \%$ of the time is spent in workplaces (e.g. called typically called apprenticeships) ${ }^{2}$ [see (OECD, 2018 $\left.\left.{ }_{[5]}\right)\right]$. Consequently, the paper considers three types of WBL:

- WBL outside of any school programme, which flows from part-time employment and/or unpaid activities such as volunteering, entered into independently by students.

- School-mediated WBL within the context of general education upper secondary programmes. These placements (e.g. internships, work placements) typically enable students to learn about work. They can motivate students to engage more seriously in classroom study, helping them connect what is taught at school to real work contexts. They help students gain mostly soft skills and are a tool for

\footnotetext{
${ }^{1}$ A number of competing, partially overlapping and often fluid pieces of terminology sit alongside "work-based learning". These include work-related learning, work-integrated learning, workplace learning, work experience, work shadowing, internships and service learning. A distinction can be made in WBL between learning at work (e.g. training done in the work place) and learning for work (e.g. during a work placement as part of a school-based VET programmes) (European Training Foundation, 2012 $[56]$ ). In this paper, the focus is on students who learn for work, i.e. engaging with WBL whilst they are still enrolled in upper secondary education.

${ }^{2}$ Apprenticeships have been the recent focus of extensive OECD work. Currently there is no agreed definition of apprenticeships for the collection of comparative administrative data. The unclear definitions have been noted by a recent CEDEFOP report (Cedefop, 2018 $\left.{ }_{[130]}\right)$ and are the subject of on-going OECD work on improving the evidence on VET. The UOE data collection is based on the following classification: first programmes in which more than $90 \%$ of the content is spent in the workplace are defined as "work-based" programmes. Second, programmes in which between $25 \%$ and $90 \%$ are spent in the workplace are "combined school- and work-based programmes". In the LSO data collection further is drawn between work-study programmes (in which students/trainees receive earnings) and combined school- and work-based programmes without systematic earnings. Third, VET programmes in which the work-based component is less than $25 \%$ are defined as schoolbased programmes $\left(\mathrm{OECD}, 2018_{[129]}\right)$. Drawing on national data and previous work on apprenticeships (OECD, 2018 $\left.8_{[5]}\right)$, the OECD has suggested to agree on a definition for apprenticeships to be used for the collection of comparative administrative data.
} 
career exploration. For the purpose of this paper, we do not look at placements that are administered for less than 10 days per school year.

- School-mediated WBL within the context of vocational upper secondary programmes. These placements (e.g. work placements within VET school-based programmes) are typically of longer duration than those undertaken within general education. Their main objective is typically for students to learn through work and develop new technical skills - as well as the soft skills developed also in shorten placements. These placements also allow employers to get to know potential recruits and for students to learn about potential employers.

7. Box 1.2 describes the definitions used by Eurostat and the EU Labour Force Survey data that is mentioned in the different chapters of this report.

\section{The structure of upper secondary education differs between countries}

\section{There can be both general education and vocational tracks}

8. Countries organise their upper secondary systems in very different ways. In most countries, students are divided into general education and vocational programmes. On average, across OECD countries, in 2016, 56\% of students in upper secondary education were enrolled in general programmes and $44 \%$ were enrolled in vocational programmes. But this hides important variation between countries: over $70 \%$ of students engage in vocational programmes in the Czech Republic compared to less than $10 \%$ in Canada.

Figure 1.2. The division of students between general education and VET varies across countries

Percentage of students enrolled in upper secondary education programmes, 2016

$\square$ Percentage of students enrolled in general education programmes

$\square$ Percentage of students enrolled in vocational education programmes

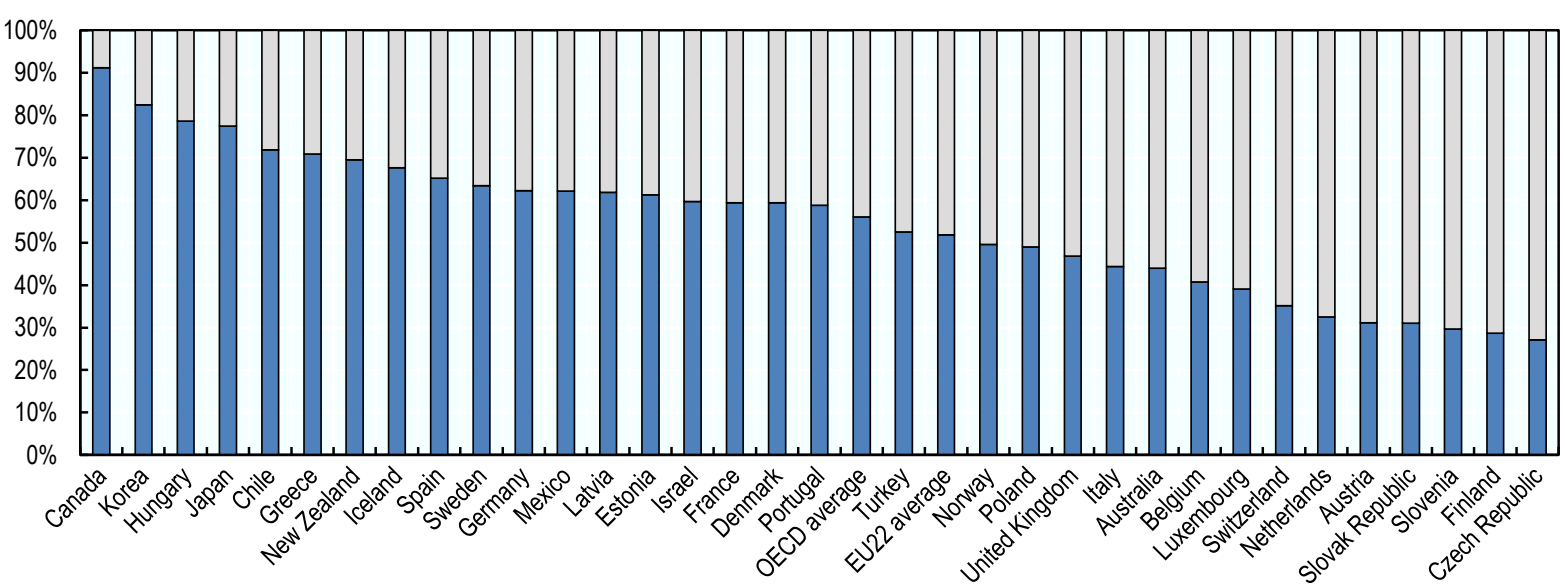

Source: OECD (2018[6]), Education at a Glance 2018: OECD Indicators, https://dx.doi.org/10.1787/eag-2018en.

\section{Vocational programmes can also be of different types}

9. In the case of students pursuing vocational programmes, there is often a choice between a school-based VET programme and a programme in which most time is spent in 
the workplace (e.g. called apprenticeship programmes ${ }^{3}$ ) (Figure 1.3). The time can be organised with students spending only one or two days a week in schools, or blocks of longer periods alternating school and time in the workplace. As mentioned before, programmes in which students spend more than half of the time in the workplace are out of scope of this study.

Figure 1.3. Students are enrolled in different types of programmes

Share of students enrolled in upper secondary education programmes (2016)

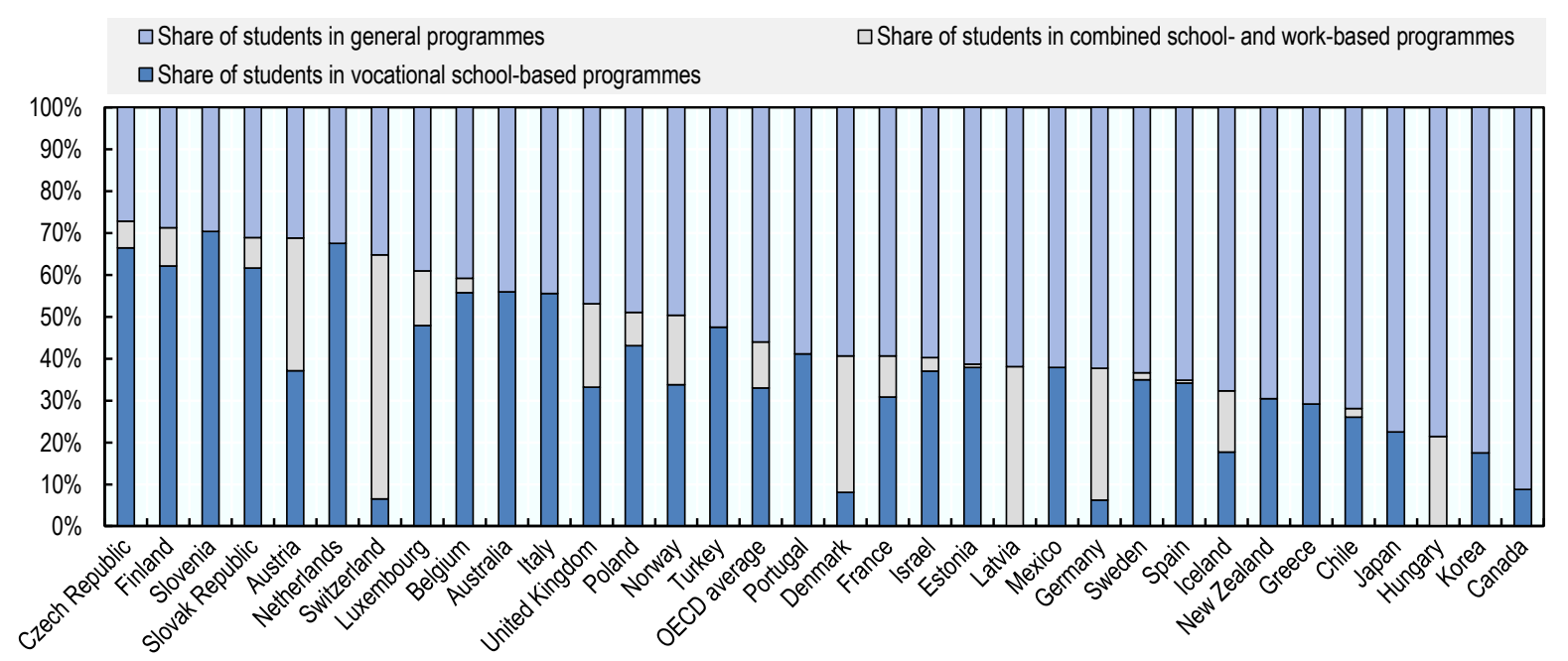

Note: The categories of "share of students in vocational school-based programmes" and of "share of students in combined school- and work-based programmes" compose the share of students enrolled in vocational programmes. The category combined school and work-based includes programmes with $25-90 \%$ of time spent at work.

Source: OECD (2019[3]), OECD.Stat, https://stats.oecd.org/\#.

10. In school-based VET programmes, the pattern is reversed, and students spend less than $50 \%$ of their time in workplaces. Commonly, learners spend $20 \%$ of their time in WBL, and the rest of their time in a school (Chapter 3 explains further and provides some country examples).

\section{Some countries do not have vocational upper secondary programmes}

In other systems (e.g. Australia, the United States), there are no separate vocational tracks in upper secondary institutions, students follow individualised "modular" programmes by choosing between different options across the spectrum of general and vocational education. Subjects can be of differing levels of difficulty (OECD, 2016 $\left.{ }_{[7]}\right)$. In Tasmania (Australia) for example, students can choose four to five subjects each year from among

\footnotetext{
${ }^{3}$ Others include apprenticeship programmes that involve concurrent school-based and work-based training, as well as programmes that involve alternating periods of attendance at educational institutions and participation in work-based training (sometimes referred to as "sandwich" programmes).
} 
145 general education options and 30 vocational ones ${ }^{4}$ (Musset, forthcoming ${ }_{[8]}$ ). In principle, such modular upper secondary programmes should allow all young people to explore career options and gain useful job skills, giving students the choice to pursue different interests, while sustaining an emphasis on core academic skills. In practice, of course, it does not always work out like this - some students can end up with a mix of subjects that provide pathways towards neither further education nor employment ${ }^{5}$. Box 1.1 sums up this typology.

\section{Box 1.1. Upper secondary education: A typology}

Upper secondary programmes can be:

1. Through an apprenticeship programme (in which WBL takes up more than $50 \%$ of the programme).

2. Through a programme of school-based VET (in which WBL takes up around $20 \%$ of the programme).

3. Through a programme of non-VET, general education.

4. Through a comprehensive approach (that can be modular - meaning that students can pursue different general education or vocational subjects).

Vocational programmes can also be defined as "modular" as they contain to varying degrees general education subjects.

\section{Upper secondary education plays multiple and essential purposes}

11. The structure of upper secondary education has served different needs in different countries: historically, upper secondary education was at the service of universities and had the mission of preparing students for higher studies (Cuadra and Moreno, 2005 [9]). This was the objective for grammar schools, gymnasiums, lycées, etc. The modern secondary school appeared at the end of the 19th century, partly with a terminal role of preparing students to enter the labour market.

\footnotetext{
${ }^{4}$ However, Tasmania is currently putting in place "packages of learning", in which vocational and general education subjects are combined for students and presented as a coherent aligned curriculum offering inquiry-based and applied learning as pedagogy. Different fields include tourism and hospitality, architecture and construction, higher-level manufacturing and agriculture, and food and natural resources. They use also advisory groups from industry. About $30 \%$ of students pursue some type of part vocational component in their senior secondary years.

${ }^{5}$ There is for example evidence from Scotland (United Kingdom) that students who come from more disadvantaged backgrounds choose less demanding or fewer subjects because they are more risk-adverse and/or lack the confidence to succeed (Klein, Iannelli and Smyth, 2016 ${ }_{[131]}$ ). Schührer, Carbonaro and Grodsky $\left(2016_{[127]}\right)$ identified similar patterns by parental education in the United States. Half of US students in grade 8 are in the basic mathematics course (Loveless, $\left.2013_{[132]}\right)$. Such differences in the timing of mathematics courses take significant consequences, because the mathematics curriculum forms a clear hierarchical sequence, and students who enter secondary school in a higher level mathematics course are more likely to progress further in the mathematics-taking sequence. Typically subjects such as history or literature that do not have clear course-taking sequences but they are differentiated using labels such as "advanced", exposing students to advanced content, and in some cases students receive college credit for taking them.
} 
12. Nowadays, upper secondary education can have different and varying missions (O’Donnell, 2018 ${ }_{[10]}$; Sahlberg, 2007 [11]):

- To lay the foundations for the next levels of education.

- To allow for immediate participation in the labour market.

- To provide all students with sound basic skills.

- To prepare for adulthood and for participation as a citizen in society.

13. The combination of these different missions can be not only challenging but even conflicting - some programmes need to be demanding to ensure they are motivating for students, while other have to focus on being inclusive (OECD, 2012[12]). Secondary education needs to provide adolescents with high-level competences whether they choose to continue studying, or entering the labour market (Sahlberg, 2007 [11]; O'Donnell, $\left.2018_{[10]}\right)$. All types of upper secondary programmes can have both formal and informal differentiation between or within schools, that can result in school choice and competition (Blossfeld et al., 2016 $[13]$ ).

\section{Interest in work-based learning is growing as participation in upper secondary education becomes more common}

14. Several decades ago, upper secondary education mainly served a highly select group, in most OECD countries today, almost everyone has access to at least 12 years of formal education. It is commonplace for more than $80 \%$ of young people finish that level in OECD countries (See Figure 1.4). These averages, however, mask important difference by gender, region and socio-economic status within each country. For instance in Lithuania in 2013, the percentage of students aged 18 to 24 who had not completed secondary education was $4 \%$ in urban and $11 \%$ in rural areas $\left(\mathrm{OECD}, 2018_{[14]}\right)$. In some countries, students might initially dropout from upper secondary education but come back to education later. In the case in Norway for example, initially $79 \%$ of students finish upper secondary education under the age of 25 (61\% from general education, and $19 \%$ from vocational programmes, see Figure 1.2). Although this is under the OECD average, many more adults finish later on in life, mostly using alternative pathways to gain upper secondary qualifications. 
Figure 1.4. In many countries, most students finish upper secondary education

First-time upper secondary graduation rates for students below the age of 25 , by orientation (2016)

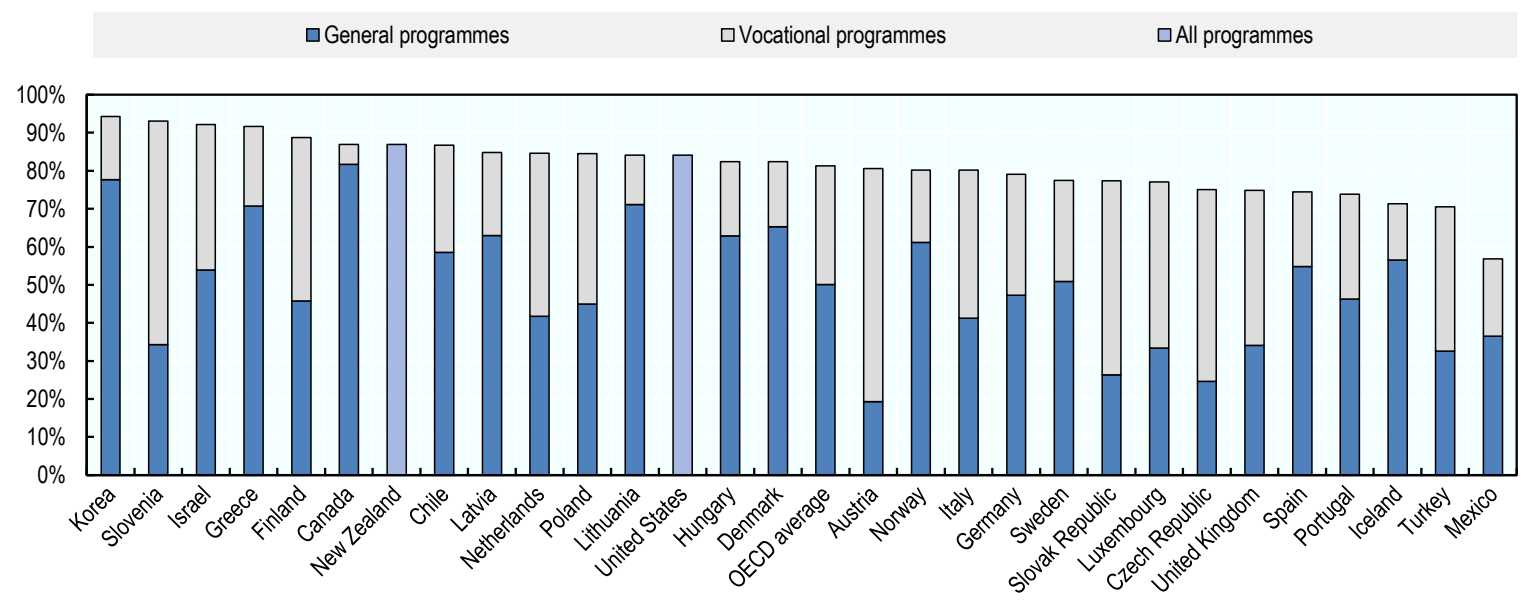

Source: OECD (2018[6]) Education at a Glance 2018: OECD Indicators, https://doi.org/10.1787/eag-2018-en.

Changes in the age of compulsory education will extend education in some countries

15. In many countries, education is compulsory until approximately age 16 (Table 1.1), which means that completing upper secondary education is not compulsory. But compulsory age has been extended to the age of 18 in some countries, and there is the expectation that in the future more students will enter and also complete this level.

\section{Staying longer in upper secondary education means that students defer entrance} into the labour market

16. Although longer participation in upper secondary education confers multiple benefits for young people, it leads to a deferral of entry to the workforce. Being full-time school students for a longer time has meant that young people experience a longer period of economic dependence and fewer opportunities to interact with a range of adults as work colleagues. This rise in educational participation also makes it more important for schooling systems to provide for diverse students, exploring means of making provision attractive to a wider range of students. 
Table 1.1. Ending age of compulsory education

2018

\begin{tabular}{ll}
\hline \multicolumn{1}{c}{ Ending age } & \\
14 & Korea, Slovenia \\
$14-15$ & Greece \\
15 & Austria Czech Republic, Japan, Switzerland \\
16 & Denmark, Estonia, Finland, France, Hungary, Iceland, Ireland, Italy, Latvia, Luxembourg, New Zealand, Norway, Poland, \\
& Slovak Republic, Spain, Sweden, United Kingdom \\
$16-18$ & Canada, Netherlands \\
17 & Australia, Israel, Mexico, Turkey, United States \\
\hline 18 & Belgium, Chile, Germany, Portugal \\
\hline
\end{tabular}

Source: OECD (2019[15]), Education at a Glance 2018: OECD Indicators, https://doi.org/10.1787/eag-2018$\underline{\text { en }}$

In some countries also, students typically experience the world of work through part-time work

Many students pursue independent work alongside of their full-time upper secondary education

17. In some countries, it is common for students to do part-time work while studying full-time in upper secondary education. There seems to be little information available on the number of hours worked, in both international comparative data collection as in national surveys. As shown by Figure 1.5, the percentage of 15-19 year-olds who engaged in part-time work outside of a work-study programme varies from almost $50 \%$ in the Netherlands to less than $1 \%$ in the Slovak Republic, with an OECD average of $12 \%$.

${ }^{6}$ In the Education and Skills Act 2008, England (United Kingdom) passed a law to make participation in education and training compulsory until the age of 18 from 2015 (UK Government, $\left.2015_{[134]}\right)$. 
Figure 1.5 Some upper secondary students are employed

Participation rates of 15-19 year-old students in employment (2017)

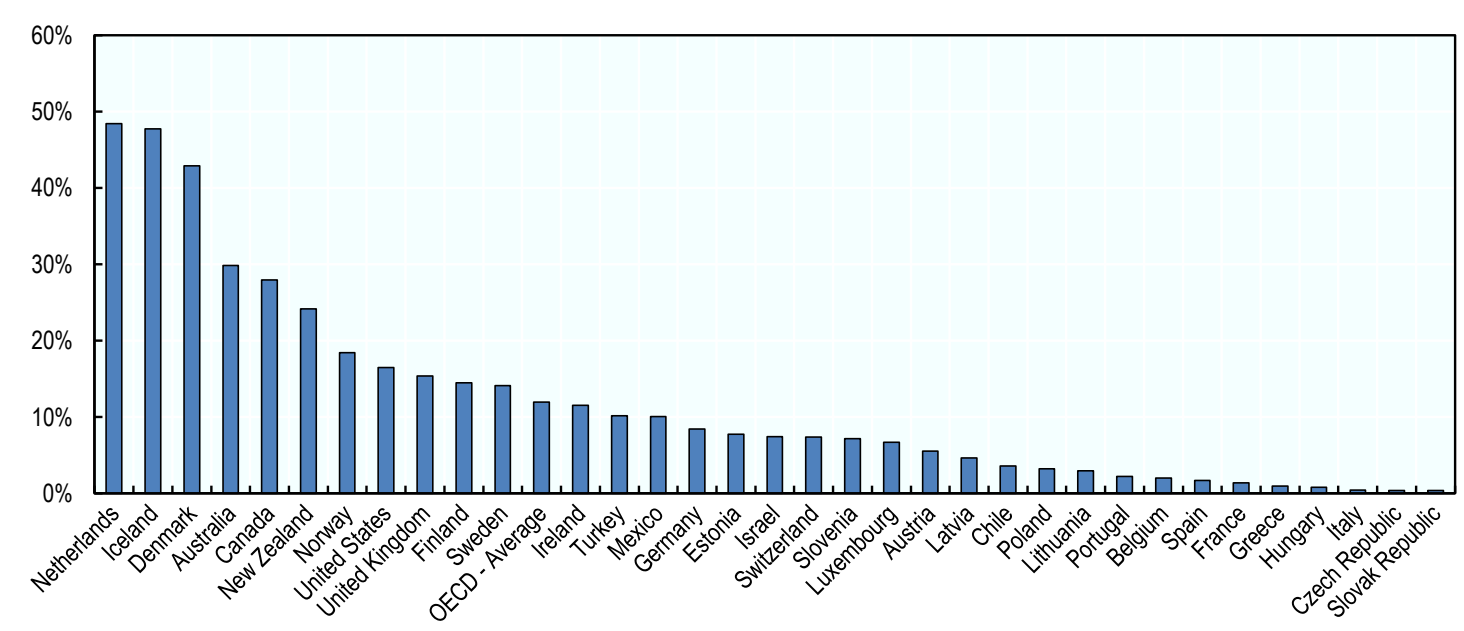

Note: Apprentices have been excluded.

Source: OECD $\left(2019_{[16]}\right)$, Transition from school to work. Indicator on the share of population by education and labour force status, https://stats.oecd.org/Index.aspx?DataSetCode=EAG TRANS\#.

\section{Participation is difficult to measure methodologically}

18. There is some methodological difficulties in estimating the share of young people who combine part-time employment with upper secondary education, with different sources varying a lot. Variation can be considerable between occasional summer employment and regular part-time work throughout the school year (Anlezark and Lim, $\left.2011_{[17]}\right)$.

\section{EU-LFS data provides some interesting insights}

19. The EU Labour Force Survey (EU-LFS) and its ad hoc module on young people in the labour market 2016 sets out significant differences in the level and type of work experiences of graduates by programme orientation (general education and vocational) (Box 1.2 and Figure 1.6) (Eurostat, 2019 ${ }_{[18]}$ ). Figure 1.6 shows the proportions of general education and vocational graduates of upper secondary education that have had access to different types of WBL, if any. Paid work experience corresponds to work pursued by students and unpaid work experience, to school-mediated WBL. 
Figure 1.6. In many countries, it is common for graduates to have work experience

Upper secondary graduates (15-34 years-old), 2016

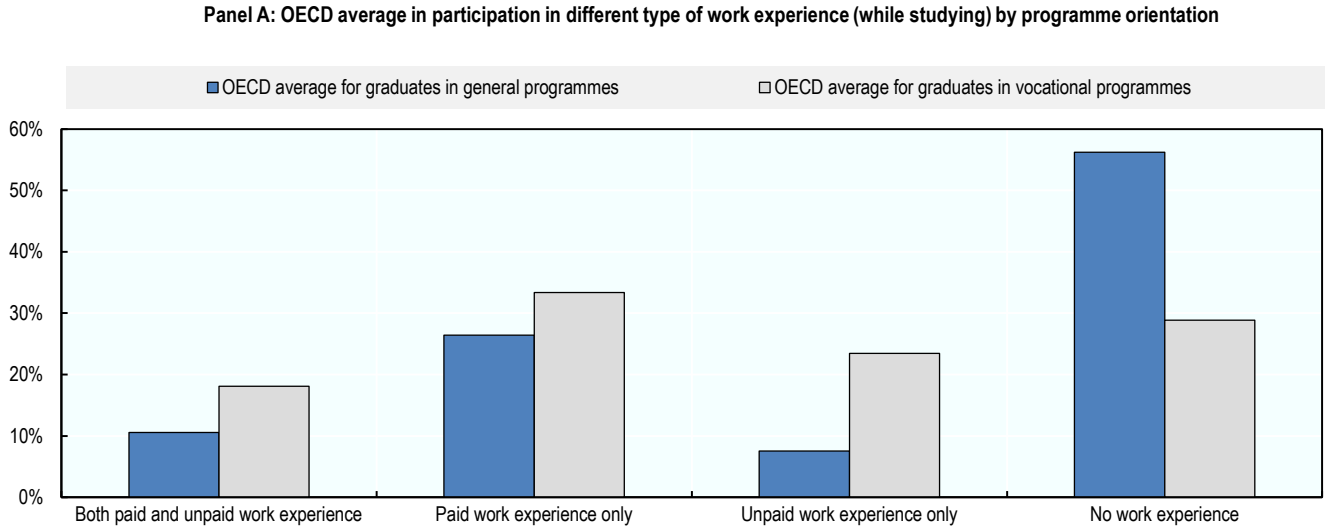

Panel B: Participation in different types of work experience for general education students

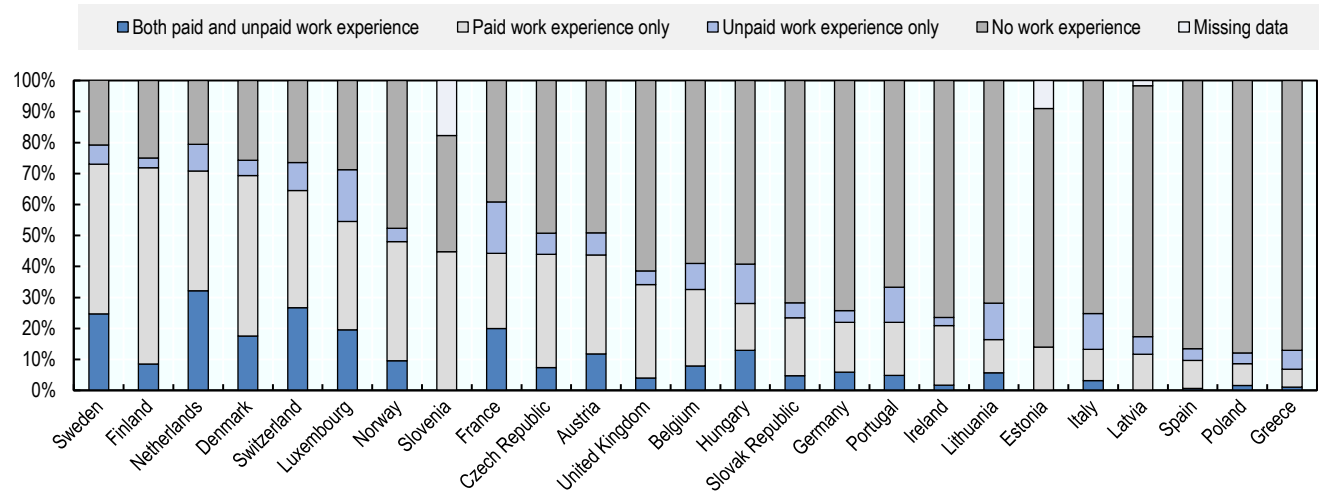

Panel C: Participation in different types of work experience for vocational students

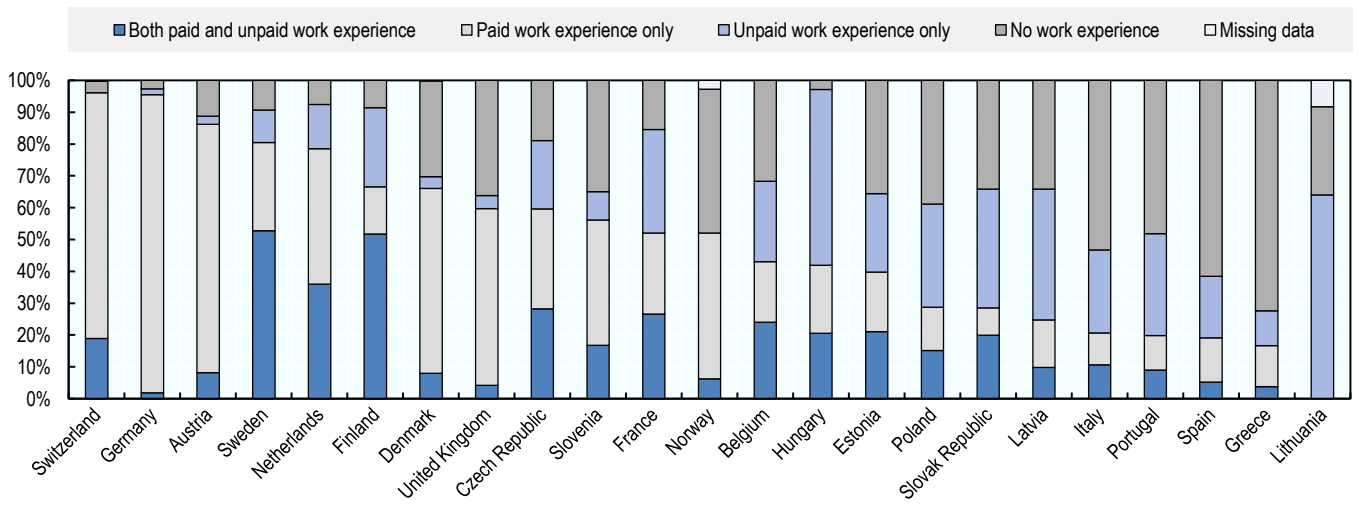

Note: The categories of "paid and unpaid work experience", "paid work experience" and "unpaid work experience" are the WBL that respondents might have done while they were studying in a school-based programmes. They can be both schoolmediated WBL and work done independently from the educational programme. The category of "unpaid work experience" excludes apprenticeships as these are defined as paid (see Box 1.2). In Panel A and Panel B, countries are ordered according to the descending sum between "both paid and unpaid work experience" and "unpaid work experience only".

Source: Eurostat $\left(2016_{[19]}\right)$, LFS as hoc modules - Young people on the labour market, https://ec.europa.eu/eurostat/web/lfs/data/database. 
20. On the one hand, as showed by Panel A, almost half of the graduates (44\%) in general education have work experience (both mediated by schools, and organised independently). There is a considerable variation among OECD countries, from around $80 \%$ in Sweden to $12 \%$ in Poland. On the other hand, as showed by Panel B, vocational graduates are much more likely to engage in some type of work-experience, as this is common for around three-quarters of them (see Panel C). Over half of general education upper secondary graduates and almost one-third of vocational upper secondary graduates have no work experience whatsoever, whether paid or unpaid, WBL, or independent.

\section{Box 1.2. The EU-LFS ad hoc module on young people in the labour market}

The EU-LFS ad hoc module (2016) covers persons aged 15-34 living in private households. Curriculum/education/qualification always refers to the respondent's highest completed education. There are two types of breakdowns of this variable: one based on payment and one based on links to education.

The work/education breakdown is:

- No work experience: did not carry out any form of work (neither paid nor unpaid) while being in education.

- Work outside of the study programmes ("outside curriculum”): did carry out work while studying, but the work was not connected to the person's ongoing studies.

- Apprenticeship: had working experience which was a mandatory part of the curriculum, the work lasted at least 6 months and it was paid.

- Mandatory traineeship: had working experience which was a mandatory part of the curriculum, the work lasted at least 6 months and it was not paid.

- Mandatory work-based learning: had working experience which was a mandatory part of the curriculum, but we have no further information on the length of time, or if it was paid or not.

- Optional traineeship: had working experience which was an optional part of the curriculum, and we have no further information on the length of time, or if it was paid or not.

The payment breakdown is:

- No work experience: not carried out any form of work (neither paid nor unpaid) while being a student or pupil.

- Paid work experience.

- Unpaid work experience.

- Both paid and unpaid work experience.

Source: Eurostat, $\left(2019_{[18]}\right)$, Employment and unemployment (LFS) - Overview, https://ec.europa.eu/eurostat/web/lfs/overview. 


\section{Part-time work is a means for some form of financial independence}

21. Students make decisions on whether or not to work based on the availability of work, their desire for financial independence, their ability to travel to the work location, their desire to concentrate on academic studies and whether or not their parents want them to work. This means in practice that the jobs available to students while they are at school are rarely linked to intentional career ambitions (Anlezark and Lim, 2011 $1_{[17]}$ ).

\section{Workplaces are powerful learning environment}

22. The main benefit of WBL and work exposure stems from the strong role of the workplace as a learning environment.

\section{Soft skills are best acquired in the workplace}

23. Workplaces provide a particularly effective environment in which to acquire soft transferable skills. A range of literature on work-readiness programmes for young adults highlights the impact of work exposure (see for example (Symonds and O'Sullivan, $\left.2017_{[20]}\right)$. Neyt et al. $\left(2018_{[21]}\right)$ reviewing evidence available across different countries, found that part-time employment alongside full-time education enables the acquisition of soft skills such as work values, communication skills, and a sense of time management. Much evidence indicates the growing labour market importance of soft skills (Deming, $2015_{[22]}$ ). A study from Finland (Lasonen, $2005_{[23]}$ ) found that workplace training taught students entrepreneurship, promoted maturity and supported the development of practical soft skills like initiative, problem-solving skills and the use of information sources. A study of sales assistants in Denmark (Aarkrog, 2005 [24]) found that soft skills were best acquired on the job. Simulating practice (e.g. through role play) at school was perceived by students as artificial and uselessWorkplaces offer very different learning environments to school classrooms.

24. There is evidence that workplace learning makes learning more attractive for students in school-based VET programmes (Smith, Dalton and Dolheguy, 2004 [25]) as is the case with apprenticeships (OECD, 2018 $\left.8_{[5]}\right)$. Chapter 3 compares WBL within school-based VET and apprenticeships. Chankseliani, Keep and Wilde (2017[26]), for example, describe a diverse literature which emphasises the value of learning through demanding, difficult, actual work, and how this can engage and empower the learner in ways that cannot be replicated by off-the-job training. WBL, mediated by schools, can also offer students the opportunity to gain maturity and confidence by interacting with a range of adults as work colleagues (Neyt et al., 2018 [21]). WBL can be particularly motivating for students who are less academically inclined and might feel discouraged by the narrowly theoretical approaches of some general education subjects (Leid Commission, 2018[27]).

\section{Bringing theory to life}

25. While some relevant theory may be best learned in a classroom environment, workplaces are often necessary to bring that theory to life. In all types of programmes, WBL can be used to develop problem-solving skills and learning skills: for example, through allowing learning to be organised around joint accomplishment of tasks, so that elements of a skill take on meaning in the context of the whole, and by allowing learner competence to build step by step (Sweet, $2013_{[28]}$ ). More specifically in the case of vocational programmes, other research has shown that it is easier to develop professional skills through work-based training than transferring theoretical knowledge, learned at school, into practice (Aarkrog, 2005 [24]; Woerkom, Nijhof and Nieuwenhuis, 2002 [29]). 


\section{WBL can help to discover the variety of jobs}

26. The career aspirations of students tend to be very narrow (Musset and Mytna Kurekova, 2018 $8_{[2]}$. But WBL enriches career thinking and serves as a career guidance tool, to explore different potential jobs and education and training options, complementing career education provided by schools such as speaking to a career counsellor. Occupational choices themselves tend to reflect individual characteristics such as gender and socio-economic status, rather than other criteria, such as personal interest, academic ability, and labour market demand (Musset and Mytna Kurekova, 2018 ${ }_{[2]}$ ). For example, high quality work placements at age 16 in the United Kingdom raised the profile of engineering and increased awareness in students of the range of careers available (Hodgkinson and Hamill, 2010 $\left.0_{[30]}\right)$. Similarly, a study of secondary school students in south eastern Australia found that students with work-based learning experience reported increased levels of career maturity (Creed and Patton, 2003 ${ }_{[31]}$ ). Survey evidence from the United Kingdom shows that two-thirds of teachers and secondary school students in England agreed that short work experience placements helped in career decision-making and navigation (Mann and Dawkins, 2014 $\left.{ }_{[32]}\right)$. The EU Partnership-Project on Work-based Learning and Teaching $\left(2015_{[33]}\right)$ surveyed teachers in nine European Union countries and found that in some countries, students said they appreciated WBL not only as a means of gaining skills but also as a mechanism to ensure that they were making well informed decisions. However, students often expressed the wish that learning at schools and in the workplace were better aligned.

\section{Workplace experience is associated with good outcomes}

27. Evidence suggests that work experience, which can take the form of either WBL or part-time work, can be a promising pathway towards better employment outcomes for young people, enabling smoother transitions into the labour market (Quintini, Martin and Martin, 2007[34]).

\section{Part-time work improves future employment outcomes}

28. Part-time paid work can teach students about the world of work and broaden their understanding of post--secondary options and pathways (Billett, 2006 ${ }_{[35]}$ ). Neyt et al. $\left(2018_{[21]}\right)$ found that student employment may motivate students to work harder in school in order to achieve a certain career goal. Evidence shows that students with work experience benefit from better subsequent employment prospects and higher wages, even when not in the same field, although the effect tends to disappear some years after graduation (see for example (Hakkinen, 2006[36]) in Finland, (Joensen, 2009 $9_{[37]}$ ) in Denmark). In Australia, students who combine school and work have reduced unemployment rates after secondary school (Anlezark and Lim, 2011 $\left.1_{[17]}\right)$. Similarly, in Sweden Hensvik, Müller and Nordström Skans $\left(2017_{[38]}\right)$ show that $60 \%$ of students worked during their schooling and that holding summer jobs increased the chance of students finding a stable job after leaving education compared to classmates who did not hold summer jobs. The effect is more pronounced during economic crises. In the United Kingdom using longitudinal data, and controlling for background characteristics, Percy $\left(2010_{[39]}\right)$ found that young people working part-time while studying are approximately twice less likely to become NEET (neither employed nor in education or training) than those with no early attachment to the labour market. Mamun et al $\left(2017_{[40]}\right)$ found that early work experience for young people with disabilities increased the probability of being employed later on, controlling for other socio-economic and health factors. 


\section{EU-LSF data can help look at the link between WBL participation and employment}

29. The importance of different types of work experience is further underlined by Figure 1.7, which shows the employment rate of young people aged 15-34 years-old, depending on the type of educational programme. The data does not allow to control for students background characteristics, and to take into account the selection bias In fact, employment rate for individuals without any work experience (whether school-mediated or outside of any school programme) while they were students is 7 percentage points lower than employment rate of students who do have work experience (see Panel A). The employment rate among upper secondary graduates in a vocational programme is usually higher than the one for those who completed a general education programme. WBL that is mandatory but shorter than 6 months ("mandatory traineeship" as defined by Eurostat) does not seem to have the same effects on the employment rate than the other types of work experiences. But looking at Panel B and C, it is possible to see that some countries present a different trend, with mandatory traineeships being the type of experience linked to the highest employment rates, namely Slovenia when looking at general education programmes' graduates and Norway when looking at vocational programmes. 
Figure 1.7. Graduates with work experience do better in the labour market than those without

Upper secondary and post-secondary non-tertiary graduates (16-34 year-olds), 2016

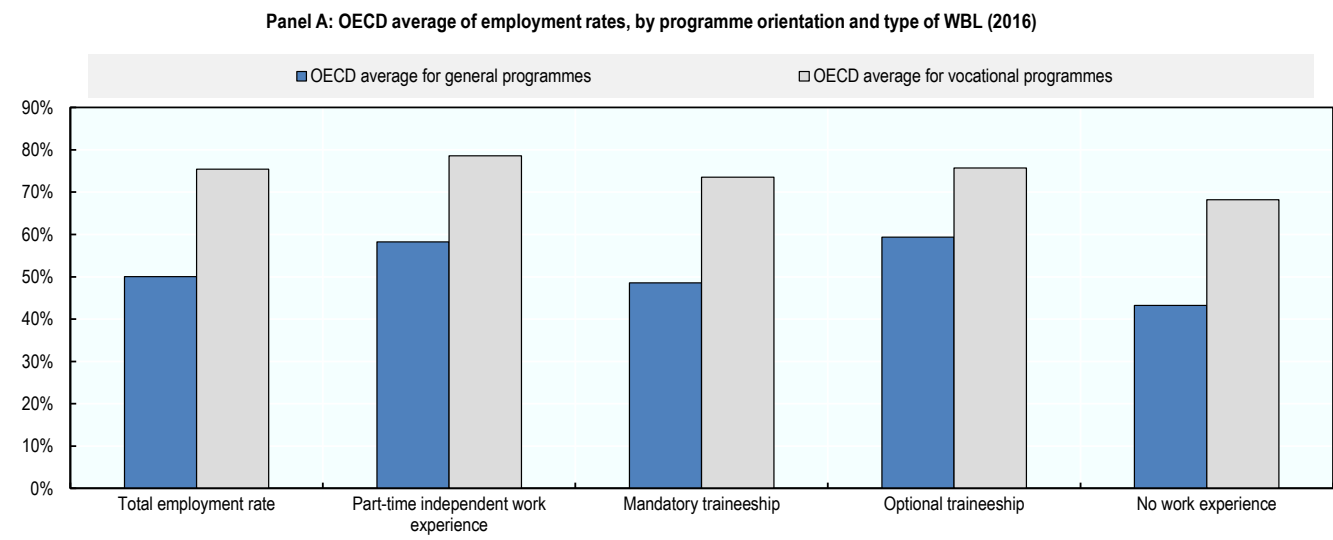

Panel B: Employment rates of general education graduates, by type of WBL

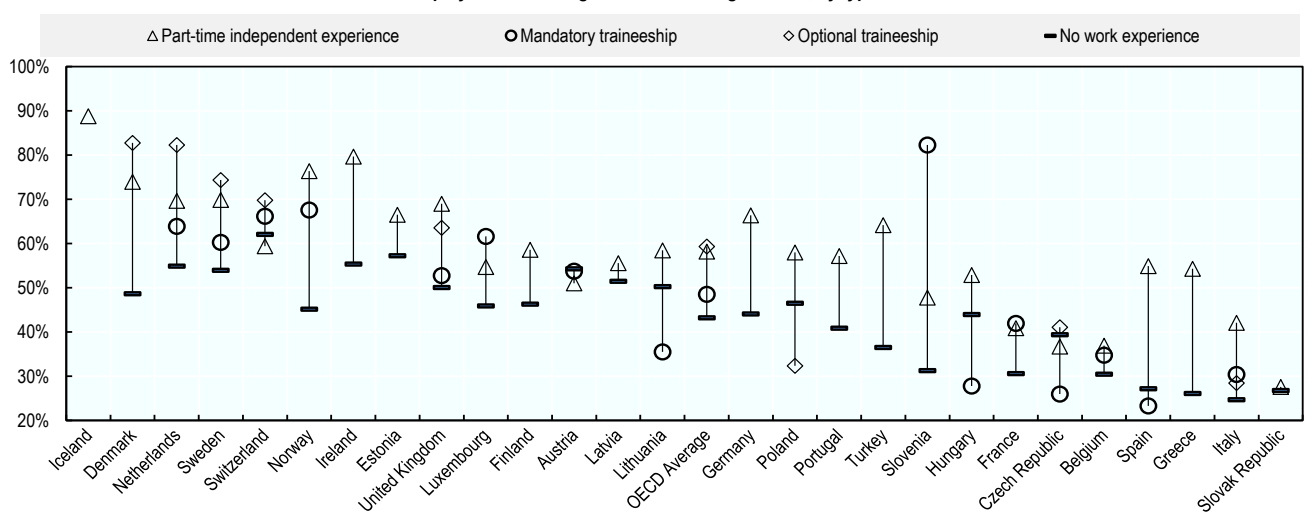

Panel C: Employment rates of vocational graduates, by type of WBL

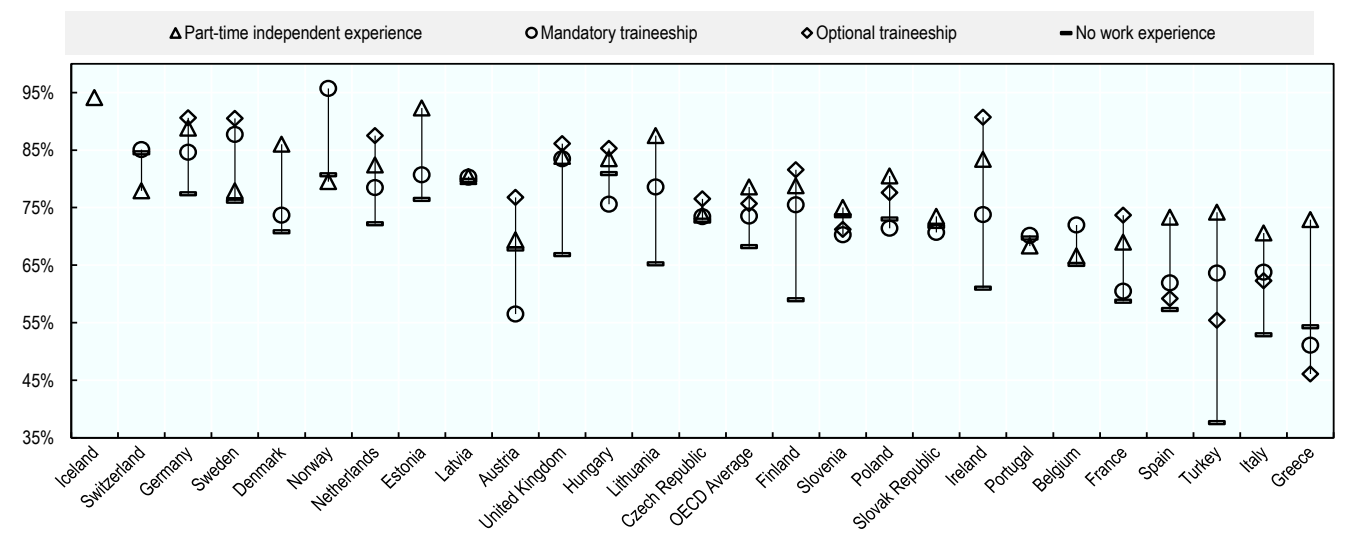

Note: The category "part-time independent experience" refers to any work activity carried out outside from the academic curriculum. The category for "total employment rate" refers to the average employment rate of the whole 15-34 year-old population. Please notice that the groups of graduates taken into account comprises both ISCED 3 (upper secondary graduates) and ISCED 4 (post-secondary non-tertiary graduates).

Source: Eurostat $\left(2016_{[19]}\right)$, LFS ad hoc modules - Young people on the labour market, https://ec.europa.eu/eurostat/web/lfs/data/database. 


\section{This is the case both for vocational graduates...}

30. The EU-LSF data suggests that learners who graduated from an upper secondary school-based VET programme which included WBL are less likely to be unemployed than those who did not receive WBL, or who worked independently in a job unrelated to their training programme, while studying (see Figure 1.7). This is consistent with national studies. In Australia, Polidano and Tabasso $\left(2014_{[41]}\right)$ found that students who take classroom-based VET subjects with workplace learning are around nine percentage points more likely to complete secondary school compared to those who undertake classroom-based VET without workplace learning.

\section{..And for graduates of general education programmes}

31. Findings mentioned above are consistent with the large positive effects found for other adolescent interventions that involve workplace experiences [see (Heckman and Kautz, 2012[42] for a review of the evidence]. For example, results from a randomised controlled trial in the United States, estimated an 11 percentage point reduction in school dropout rates among "at-risk" upper secondary students who participated in Career Academies, a career oriented education programme that, among other things, gives students workplace learning opportunities (Kemple and Snipes, $\left.2000_{[43]}\right)$. Arum and Way, $\left(2004_{[44]}\right)$ found that in the United States (using longitudinal data from more than 1200 students) students who had undertaken a work placement while in secondary school had better labour market outcomes than those who had not - especially women. Neumark and Rothstein, $\left(2005_{[45]}\right)$ analysing longitudinal data found that school-mediated internships boosted employment and decrease inactivity in adulthood, especially for women in the United States. In Denmark, population data taken from the national employment service shows that $55 \%$ of the former clients had found employment through contacts first made during an internship (Paparella and Savino, 2008 $8_{[46]}$ ). A study on WBL in Australia found that after controlling for other factors, work placements increased students' labour market outcomes (Smith, Ferns and Russell, 2014 ${ }_{[47]}$ ). In the United Kingdom, 66\% of employers say work experience is a significant or crucial factor in their recruitment of young people compared to $49 \%$ who say academic qualifications are critical or significant factors and $50 \%$ who say the same of vocational qualifications (UKCES, $\left.2015_{[48]}\right)$. A review of a diverse range of work experience programmes in the United States (Sattar, 2010 [49]) found that vocational training combined with work placements can improve employment, earnings and academic outcomes for young people.

\section{There are concerns about the decline of student part-time employment in some countries}

32. Given the benefits of student part-time work, there are some concerns about its decline In 2017, in the United States 29\% of 16-19 year olds enrolled in full-time educational programmes had a part-time job, and $35 \%$, a summer job, down from $43 \%$ and $52 \%$ respectively in 2000 (Pew Research Centre, 2018[50]). Decline has followed a similar pattern in the United Kingdom: in 1997, 42\% of 16-17 year-olds enrolled in full-time education were also working part-time, compared to $18 \%$ of the same age group in 2014 (UKCES, 2015[51]). Researchers have suggested multiple reasons for fewer young people working, including: fewer low-skill, entry-level jobs (such as sales clerks, or office assistants) than before, less flexibility from education providers, students concentrating harder on academic studies and more students doing unpaid work to document these experiences in their higher education applications, which does not count as being employed 
(Pew Research Centre, 2018[50]; UKCES, 2015 [51] $)$. Automation of jobs is expected to lead to further decline of the number of teenage student jobs ${ }^{7}$ (Nedelkoska and Quintini, $\left.2018_{[52]}\right)$.

\section{Part-time work can, if long hours, be detrimental to education outcomes}

33. How much is too much work? Vickers, Lamb and Hinkley $\left(2003_{[53]}\right)$ reviewing evidence in Australia found that working between one and five hours a week in year 9 (grade in which students are typically 14-15 years old) had no detrimental effect on year 12 completion $^{8}$, although working more than five hours did. More recently, using data from the Longitudinal Surveys of Australian Youth (LSAY) (and controlling for some background characteristics), Anlezark and Lim, $\left(2011_{[17]}\right)$ found that working more than ten hours a week in year 11 and 12 had a small negative impact on school performance, but a positive one on future employment prospects. These approaches make cross-study comparisons difficult, and it would be naive to assume that the characteristics of students who work in years 9 or 10 are the same as those who work in years 11 or 12, and that their effects will be the same. Another explanation is that hours of study are foregone by working, and students may be distracted by work, or too tired to concentrate properly at school. It is not just the number of hours of work, but the intensity which affects school performance (Staff and Mortimer, 2007 ${ }_{[54]}$ ).

\section{Some young people are better able than others to manage the competing demands of $W B L$}

34. Young people from more advantaged backgrounds are more likely than their less advantaged counterparts to work part-time while studying. However, they work for fewer hours. In contrast, youth from more disadvantaged backgrounds and those with poorer grades and lower educational aspirations, if they do work, are more likely to work longer hours when at school and have poorer educational outcomes (Shanahan and Flaherty, $\left.2001_{[55]}\right)$. But the research does not allow to identify the reason for which students decide to work longer hours. On the one hand, such a decision could be influenced by their lower socio-economic status and their financial needs, as well as by their poor school performance. However, on the other one, it could be that their poor school performance is the result of longer hours worked, or of the field in which they work - either connected or not to their studies. Without controlling for background characteristics - socio-economic status in particular - it is not possible to establish a direct link between participation in WBL - and future outcomes. Students who come from more advantaged background have both better educational outcomes, and a higher likelihood of finding a job.

\footnotetext{
${ }^{7}$ But an important caveat to bear in mind is that young people are better skilled than their older counterparts so they may find it easier to adapt to new jobs, including those created as a result of the introduction of new technologies (Nedelkoska and Quintini, 2018 [52]).

${ }^{8}$ Similarly, an older study, (Robinson, 1999 ${ }_{[133]}$ ) found working more than ten hours a week in years 11 and 12 negatively affected tertiary entry rank (TER) scores, and working in year 11 for more than ten hours a week affected year 12 completion.
} 


\section{School-mediated WBL also has benefits for the different stakeholders involved}

\section{Employers gain from school-mediated WBL}

35. From the employer's point of view, the benefits of WBL include the direct productive contribution of the student and also non-financial benefits like increased staff morale and the chance to enhance corporate reputation through being seen as contributing to the common good. This may indirectly increase profits if companies seen as socially responsible are more likely to sell their products and services (however these benefits are difficult to measure) (see (European Training Foundation, 2012 [56]) for an explanation of the different benefits for employers). In the case of placements within vocational programmes, WBL also allows employers to equip people with the skills that they need, particularly in areas where there are critical shortages. It gives them the chance to test out the student on placement as a potential future recruit and to promote careers within their organisation or sector (European Training Foundation, 2012 ${ }_{[56]}$; Hooley, Watts and Andrews, 2015[57]). Research in Australia, using case studies in the health and care professions, also suggests that WBL can encourage innovation in enterprises that offer placements (Hodge et al., 2017[58]). A study evaluating employer benefits shows that WBL in school-based VET programmes (20-40 weeks in total) facilitates future recruitment and lowers its costs, while increasing the skills and motivation of company staff, especially those employees who supervise students. Employers reported that all students do some productive work, but students who carry out their traineeship in the third (final) year of the programme are more skilled and therefore more productive than those in earlier parts of their programme (Karlson and Persson, 2014[59]).

\section{As does society as a whole}

36. From a societal point of view, school-mediated WBL can be expected to improve the balance of skills supply and labour market demand, as signalled by employers' offer of work placements. This is especially in the case of school-based vocational programmes. Promoting WBL - and transferring the costs of some of the learning units from the educational institutions to companies, can also reduce public expenditure (e.g. reducing costs for VET schools of purchasing costly equipment) (European Training Foundation, $\left.2012_{[56]}\right)$. In the case of vocational programmes, employer willingness to offer work-based learning is an important indicator of their support for the associated programme of learning. These benefits to different parties are summarised in Table 1.2. 
Table 1.2. Possible benefits of work-based learning

\begin{tabular}{|c|c|}
\hline Point of view of & Potential benefits \\
\hline Learner & $\begin{array}{l}\text { Development of craftsmanship and deep professional expertise. } \\
\text { Builds transversal soft skills, including teamwork and communication skills. } \\
\text { Informed career choices and career management skills; improved self-confidence. } \\
\text { First working experience which facilitates entry to the labour market. }\end{array}$ \\
\hline Employer & $\begin{array}{l}\text { Positive impact on supply of qualified labour. } \\
\text { Addresses skills gaps through tailor made training. } \\
\text { Positive effect on recruitment and retention. } \\
\text { Improved productivity and performance. }\end{array}$ \\
\hline General education schools & $\begin{array}{l}\text { Positive effect on students' motivation. } \\
\text { Career guidance tool. }\end{array}$ \\
\hline VET schools & $\begin{array}{l}\text { Better quality of VET programmes and of learning outcomes. } \\
\text { Enhancement of relevance and responsiveness of VET. } \\
\text { Positive effect on teaching staff competences and development. } \\
\text { Better co operation between VET schools and employers. }\end{array}$ \\
\hline Society & $\begin{array}{l}\text { Skilled labour force which responds better to labour market needs. } \\
\text { Positive contribution to youth employment. } \\
\text { Cost sharing of VET between the state and employers. } \\
\text { Combined governance of VET. } \\
\text { Contribution to innovation and creativity. } \\
\text { Has the potential to strengthen social inclusion and improve equal opportunities. }\end{array}$ \\
\hline
\end{tabular}

Source: Adapted from European Commission (2013[60]), Work-based Learning in Europe: Practices and Policy Pointers, http://ec.europa.eu/dgs/education culture/repository/education/policy/vocationalpolicy/doc/alliance/work-based-learning-in-europe en.pdf. 


\section{Chapter 2. WBL in general education programmes}

Chapter 2 focuses on work-based learning (WBL) within general education. While traditionally general education did not include a focus on job specific skills nor on WBL, in recent years, it has been introduced, and it is now an option in many places. There is limited evidence on the costs and benefits of WBL when the WBL forms part of these types of programmes, but the chapter highlights some valuable policy messages for countries and schools.

\section{The use of WBL is increasing in general education}

\section{Traditionally general education include neither specific job skills nor WBL}

37. As noted above, historically upper secondary education, as delivered through grammar schools, gymnasiums, lycées, etc., was at the service of universities and had the mission of preparing students for higher education (Cuadra and Moreno, 2005 ${ }_{[9]}$ ). General education programmes are designed to develop learners' general knowledge, skills and competencies, often to prepare them for other general or vocational education programmes at the same or a higher education level. General education does not prepare learners for employment in a particular occupation, trade or class of occupations or trades $(\mathrm{OECD}$, $\left.2018_{[6]}\right)$.

\section{There is a rise in the interest around WBL in general education}

38. Recent years has seen the introduction of more practical options, including WBL, in general education in some systems. It is often considered as an effective tool to motivate students. ${ }^{9}$ In England (United Kingdom), work experience is considered a key component of study programmes for all young people aged 16-19 years-old, with the objective of giving students the opportunity to develop their career choices, and gain soft skills in real workplaces. As such, it is compulsory for students in academic, technical and applied pathways but can take a variety of different forms including work tasters, volunteering or a work placement (Department for Education, 2019[61]). Italy too had introduced mandatory WBL for all students in upper secondary education (Box 2.1).

\footnotetext{
${ }^{9}$ Also with the purpose to motivate students, in the United States, students can pursue "enriched learning", and gain tertiary education credits, together with a work placement. Emerging evidence indicates that students enrolled in these types of programmes had a higher chance of graduating from secondary education and further enrol or graduate from post-secondary education than those who despite applying - were not selected (Johnston et al., 2014 ${ }_{[125]}$; OECD, 2018 ${ }_{[126]}$ ).
} 


\section{Box 2.1. Compulsory WBL in all upper secondary programmes in Italy}

In Italy, compulsory work-based learning was introduced in 2015 for the two final years of upper secondary education. The period is of 200 hours of work experience in the lyceum (general education) and 400 hours in the technical and professional schools. An evaluation after the first year of implementation found that after one year already $80-90 \%$ of vocational students enrolled in the third year of their track, and a little lower for general education students, were benefitting from the programme. Moreover, around $10 \%$ of the students involved in the mandatory work experience in Tuscany then found a job in the enterprise where they spent their time (Maisto and Pastore, 2017[62]). The evaluators concluded that it is too early to assess of the impact the reform on the length of the school-to-work transition and employment chances of graduates.

An interesting political economy argument that was put forward within the programme evaluation is that implementing such reforms can help pave the way towards more in-depth reforms, such as the introduction of work-related learning at the university level and in the promotion of apprenticeships for young people.

Source: Pastore, F. (2017[63]), "Why so slow? The school-to-work transition in Italy", IZA Discussion Paper, No. 10767, http://ftp.iza.org/dp10767.pdf.

\section{$W B L$ is more commonly optional then mandatory for students in general education}

39. When WBL is part of general programmes, it is more often voluntary and it is typically of between two and 12 weeks duration. In New Zealand and Ontario (Canada), for example, work-based learning can contribute credits towards upper secondary qualifications (O'Donnell, 2018 ${ }_{[10]}$ ). Students in Australia when choosing a personalised set of subjects amongst many, can pick between varying forms of WBL - such as work experience or "internship". In the Australian Capital Territory, for example, students can gain credits in "work experience" by pursuing a placement of two weeks per semester in the two last years of secondary school (ACT, 2018 [64] $)$. 
Figure 2.1. In general education, students may have access to WBL and/or work

15-34 year-old graduates in upper secondary general education, by type of exposure to the workplace (2016)

$\square$ Mandatory traineeship $\quad \square$ Optional traineeship (part of education) $\quad \square$ Part-time independent experience $\square$ No work experience $\square$ Missing data

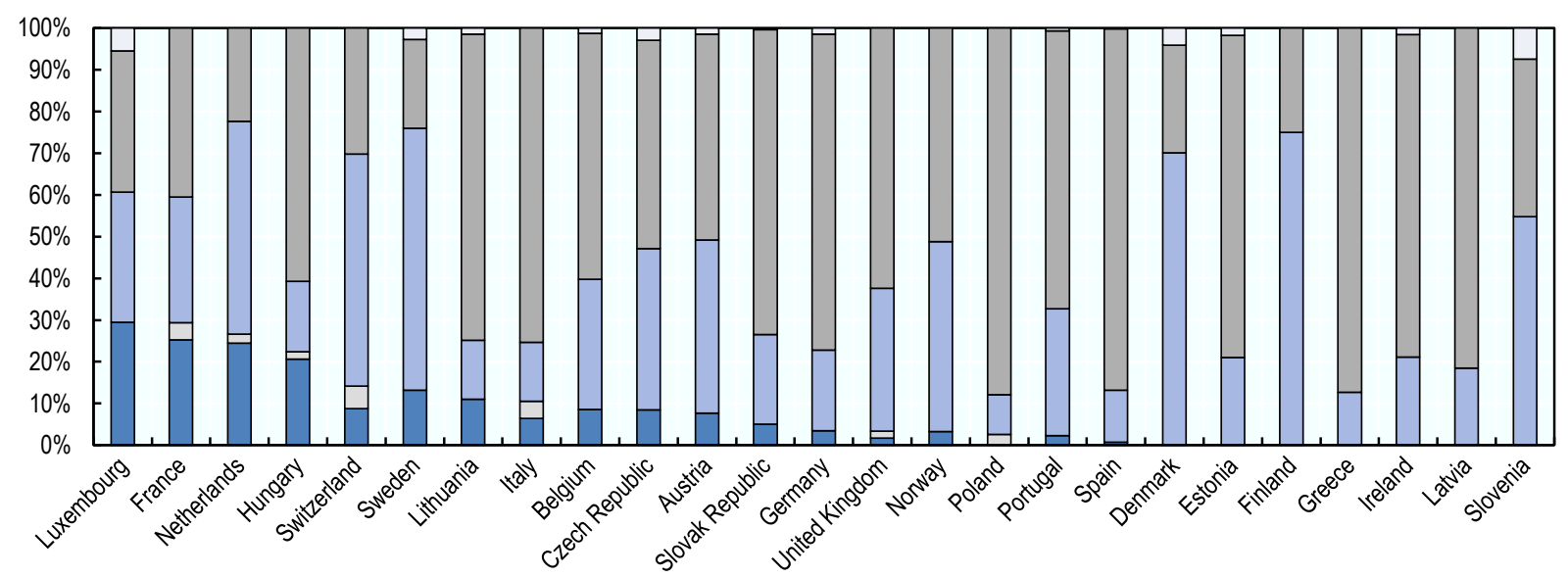

Note: Apprenticeship, mandatory traineeship, mandatory work-based training and optional traineeship are listed by the dataset as all the mutually excluding categories of WBL. The distinction between apprenticeship and mandatory traineeship is based on duration and payment, and when is not possible to make it, the category of "mandatory work-based training" is used. The category "apprenticeship" is excluded as this study focuses on school-based programmes. The category "mandatory work-based learning" does not include information about the length of the placement, which could be more than 6 months, and therefore, is also excluded from the scope of this study (see Box 1.2 on the LFS definitions). The OECD average column has been computed based on the data reported by the LSF. The shares displayed here are the relative shares of the included categories out of all the general education graduates. The columns do not always add up to one as some countries have missing data in some categories.

Source: Eurostat (2016[19]), LFS ad hoc modules - Young people on the labour market, https://ec.europa.eu/eurostat/web/lfs/data/database.

40. Figure 2.1 shows clearly that school-mediated WBL tends not to be very common among general education students. In fact, only Luxembourg, France, the Netherlands and Hungary ${ }^{10}$ show a participation in WBL above $20 \%$. On the other hand, the choice of independent part-time experience (meaning, not mediated by the school), tends to be more widespread, reaching almost $90 \%$ in Iceland, although it is less common in other countries, especially in Southern and Eastern Europe.

\section{PISA data show that WBL is more common in VET programmes than in general education ones}

41. Results from the Programme for International Student Assessment (PISA) 2012 survey show that only $27 \%$ of 15 -year-old respondents reported that they had participated in an internship ${ }^{11}$ (Figure 2.2). As expected, the proportion of VET students who had

${ }^{10}$ Some of this might be driven by which programmes are classified as "general" in ISCED mappings. Hungary for example has a vocational programme (delivered in vocational gymnasiums) that is classified as general because it give access to university and the vocational content is less large than in the other vocational track, which may explain the result.

${ }^{11}$ In PISA, $14 \%$ of 15 -year-old students are enrolled in a pre-vocational or vocational track. 
undertaken an internship is a lot higher than general education students who similarly undertook an internship.

Figure 2.2. VET students participate more in internships in many countries than students in general education

Selected OECD countries, percentage of 15 -year-olds having participated in an internship, by programme orientation (2012)

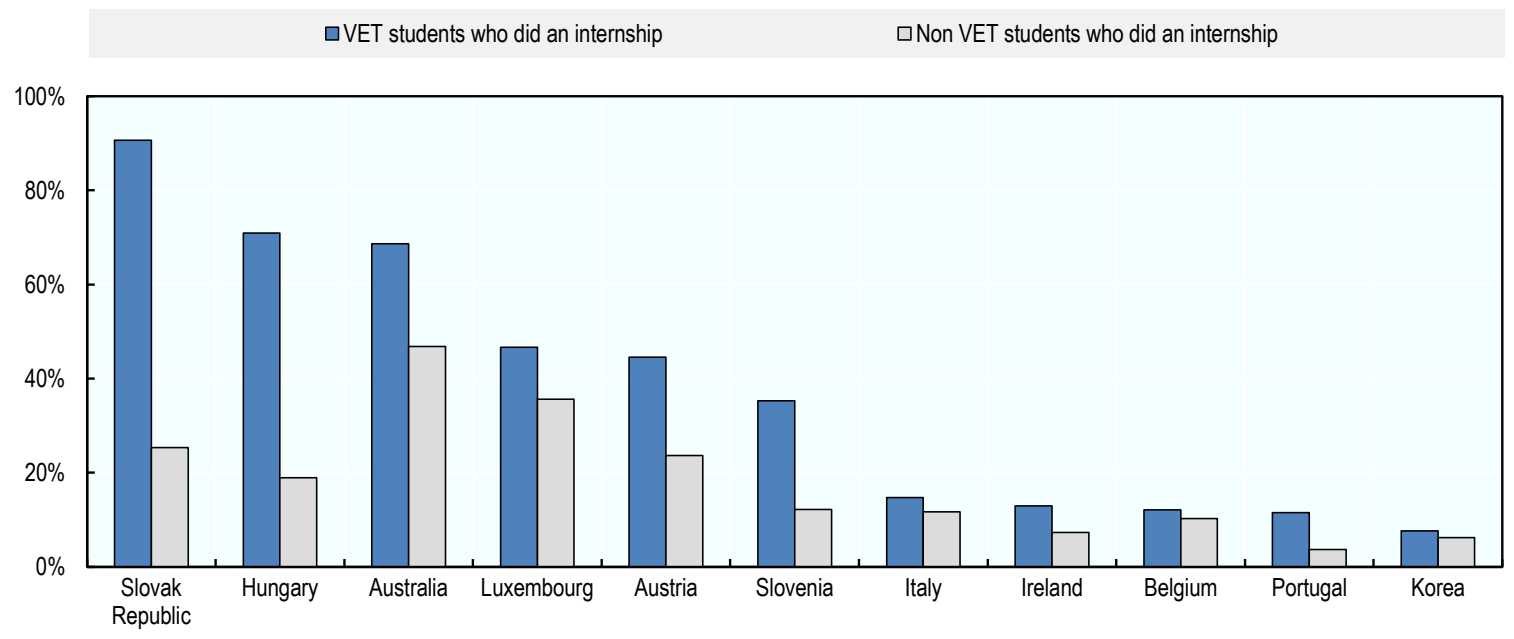

Note: Not all OECD countries decided to add the section on career guidance to the PISA test. Source: OECD (2012[65]), PISA 2012 (database), https://www.oecd.org/pisa/data/pisa2012databasedownloadabledata.htm.

\section{There is limited empirical evidence on the costs and benefits of WBL for school-based programmes}

42. Although the theoretical benefits of WBL as part of school programmes are well described (as developed in Chapter 1), there is limited quantitative empirical research on the costs and benefits of WBL to employers when the WBL forms part of a school-based programme, compared to apprenticeships for which costs and benefits are better documented (see for example, (Kuczera, 2017 $[66]$ ). The employer costs involved in offering shorter work placements (for both general education and vocational programmes) are different from those in apprenticeships, with a smaller administrative burden, usually no wage costs and fewer demands on the time of the firm's employees. There are costs around the mentors or supervisors of training in the workplace. Costs to employers will vary according to the length of the programme, the amount of training provided, the level of the skills being taught, and the nature of participants. Costs can be higher if disadvantaged or participants with special needs are targeted because they need more training time from supervisors and potentially additional support. Quality training delivers high skill levels, which in turn lead to greater productivity, and so lower overall costs (European Training Foundation, 2018[67]). Chapter 4 mentions some of costs and challenges around the provision of WBL. 


\section{There is even less evidence specifically for WBL within general education}

There is even less evidence on specifically the costs and benefits for WBL in general education programmes. However, there is a reasonable amount of evidence that "internships", typically as part of post-secondary education and training programmes, have positive effects on labour market outcomes of those involved (O'Higgins and Pinedo, $2018_{[68]}$ ) (Box 4.4). Often data on work placements, their length, prevalence, and type of employer are lacking. There is a strong need for better research on WBL within both VET and general upper secondary school educational programmes.

\section{But implementation and quality matters}

43. However, research found that some work experience programmes failed to improve young people's prospects. Robert and Saar $\left(2012_{[69]}\right)$ compared the effect of work experience on occupational outcomes in six Central and Eastern European countries and found that study-related work experience reduces the duration of job search and improves employment prospects. At the same time, part-time employment not mediated by schools negatively affects these outcomes. Although the data does not include information about students' background characteristics which also (at least partly) drive labour market outcomes, this suggests that the occupational and educational relevance of WBL is an important factor that can make or break programme success. The work also identified variation in outcomes with several studies finding impacts at some sites, but not others suggesting that the quality of local implementation is also important.

\section{Policy messages}

\section{Under certain conditions, allow for part-time work}

44. The evidence reviewed earlier shows that working part-time while in full-time upper secondary education is beneficial under certain conditions and for certain student groups, countries and schools should continue allowing for part-time work. Given these benefits, in some cases, schools can facilitate it for students who do not benefit from this exposure to the labour market. Countries and schools should make sure that the work is not strenuous (both physically and in terms of working hours), and pay special attention to the working conditions. Evidence can also be collected on how many hours can students work, and in which types of work, in order to set more precise recommendations for specific groups, and settings.

Given the benefits of work exposure, and concerns about its decline in some countries, develop policies to promote school-mediated WBL within general education programmes

45. School-mediated WBL can be designed with the aim of increasing work exposure - in both countries where student part-time work was never very developed and in countries where it is declining. As mentioned in Chapter 1, many students do not enter tertiary education. Given that little VET takes place at the upper secondary level in some countries, many young people enter the labour market without job specific preparation and/or skills. Likewise, employer concerns about lack of experience and life experience amongst upper secondary students (see Figure 2.3 on what employers in the United Kingdom report about young graduates) provides a strong footing for the development of WBL. 
Figure 2.3. Employers' views on potential young recruits

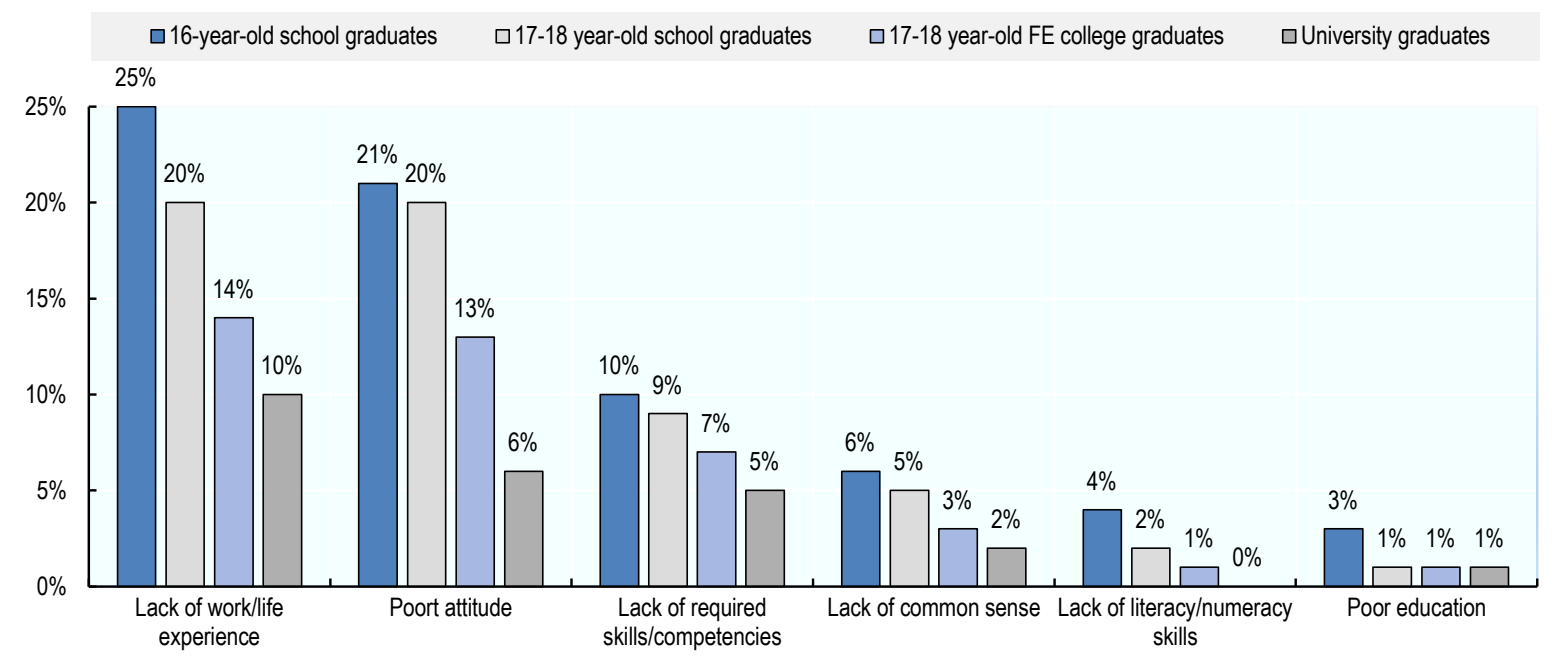

Source: UK Commission for Employment and Skills (2015 [70]), Catch 16-24: Youth Employment Challenge, https://www.gov.uk/government/publications/catch-16-24-youth-employment-challenge.

46. This argues for the strengthening of WBL within school programmes - as a means for students to gain from the work exposure that they once achieved through student jobs, and to realise the benefits of WBL. France, for example, introduced the "civic service" in 2010 to offer 16-25 year-olds the opportunity to carry out general interest projects for 6-12 months while receiving a living allowance, initially targeting people from economically deprived areas (Becquet, 2013 $\left.{ }_{[71]}\right)$. Similarly, since combining school and work can be detrimental in some cases, systems have to identify and monitor those at risk from this activity.

\section{Identify students who would gain the most from WBL and offer them school-mediated WBL}

47. Schools and countries could target students who would benefit the most from school-mediated WBL, acknowledging also that the characteristics of the target group might vary across countries. This group could include, for example, students who have never had workplace exposure and/or students who do not intend to pursue post-secondary education. Given the association between school-age work exposure and its many benefits, including future economic outcomes, education systems should give consideration to making school-mediated WBL compulsory or available to learners, notably those at risk of poor outcomes.

\section{Make sure that adequate quality assurance mechanisms are in place, and that WBL is credit-bearing}

48. Learning through WBL is purposeful in that it is meant to raising the interest of young people and maintain and encourage further engagement in the labour market. Inappropriate placements, or placement for placement's sake, may, in fact, hinder this goal. Work placements tend to work best when they are credit bearing, so that work-based and school-based learning effectively complement each other. In Victoria (Australia), students can integrate on-the-job experiences with their secondary study, and gain credits towards 
their VCE (Victorian Certificate of Education) or VCAL (Victorian Certificate of Applied Learning) In South Australia, students can do short-term industry placements, bearing credits, which aim to help career exploration and enhance students' understanding of the work environment. Such placements follow guidelines and cannot exceed 40 days per year (300hrs) (Musset, forthcoming ${ }_{[8]}$ ). In addition, well-designed quality assurance mechanisms can effectively assist employers with the tasks of managing a trainee in a less onerous manner, while ensuring that the students benefits from a quality placement. One good model for how this might be achieved, developed for apprentices and therefore quite demanding, but with wider application, at least in some parts, is the Swiss Qualicarte (Box 2.2).

\section{Box 2.2. The Qualicarte in Switzerland}

In Switzerland, the Qualicarte, set out below, offers to employers both a checklist of how to manage an apprentice, and a form of self-assessment, so it both assists the employers by guiding them through the tasks they need to perform in WBL, and supports quality. For each bullet point, training employers are invited to self-assess the extent to which they comply with expectations.

\section{Hiring: The receiving company/institution establishes the conditions of hiring.}

- The criteria defining the expected profile of the trainee are announced.

- Interviews are conducted with the applicants, in addition to other recruitment tools.

- The results of the application process are communicated clearly.

- Information is provided on working conditions.

- The terms of contract are explained to the trainees.

Starting the training: A special programme is prepared for the initial period spent in the company/institution.

- The persons responsible for the traineeship are designated.

- The trainee receives a personal welcome.

- Information is provided on the activities of the company/institution

- The trainees are informed about work, security, health and hygiene regulations.

- A workplace equipped with the necessary tools is available to the trainee.

- The trainees are informed about the importance of the training plan.

- There is a regular dialogue between the trainee and supervisor during the probationary period. 
Training: The company/institution helps the trainee acquire competences required in the labour market and takes the time to provide training and progressively transmit their knowledge and skills.

- The supervisor defines clear and measurable objectives.

- The different working methods and procedures are planned, demonstrated and explained.

- Tasks carried out by the trainee are subjected to qualitative and quantitative control.

- The trainee progressively becomes involved in the company's activities.

- The performance of the trainee in the VET school and industry courses is taken into account and discussed.

- The supervisor supports each trainee according to his/her potential and needs.

- The supervisor prepares a training report.

- The supervisor takes into account the feedback received from the trainee as much as possible.

Responsibility of the training company/institution: The company/institution is engaged and collaborates with all those involved in the training.

- If the trainee has difficulties, the supervisor contacts his/her parents, school or relevant VET office.

- If there is a risk of breaking off the traineeship contract, the training company/institution immediately informs the relevant authorities.

- The supervisor continuously updates his/her skills needed to support trainees.

- The company/institution provides the supervisor with the necessary time, financial and material resources.

Source: CSFO (2016[72]), QualiCarte, http://www.berufsbildung.ch/dyn/bin/7361-7626-1qualicarte fr 2016i.pdf.

\section{Collect information and data about students and their participation in WBL (both} part-time work, and school-mediated WBL)

49. Although WBL is not uncommon for general education students, there is often little information collected by schools and countries on how many students participate in such opportunities, and at which type of workplaces. The collection of data on the socio-economic background of students and other background characteristics such as gender and migrant background would allow to understand which subgroups can be targeted in priority. It can also help address issues around selection bias when studying the labour market outcomes. Destinations surveys of graduate leavers are usually considered a good, and simple, tool - and can establish whether upper secondary students did WBL, and in which field, whether they are pursuing further study, and if they are unemployed or 
otherwise not in the labour market. A survey can also ask graduates what they thought of their placement. In this way such surveys also become a tool to monitor quality (OECD, $\left.2010_{[1]}\right)$.

\section{Box 2.3. Summary of the policy messages}

- When applicable, make sure that students can work part-time, under certain regulatory conditions serving the students' best interest (setting a maximum number of hours per week during school terms, for example).

- Given the benefits of work exposure, and concerns about its decline in some countries, develop policies to promote school-mediated WBL within general education programmes.

- Identify students who would gain the most from WBL -including those who wish to enter the job market directly and disadvantaged students- and offer them school-mediated WBL

- Make sure that the adequate quality assurance mechanisms are in place, and that school-mediated WBL is credit-bearing.

- Collect information about students and their participation in WBL (both part-time work, and school-mediated WBL). 


\section{Chapter 3. WBL in school-based vocational programmes}

Chapter 3 focuses on work-based learning (WBL) within school-based vocational programmes, as opposed to apprenticeships. This paper encourages school-mediated WBL to be mandatory in all vocational programmes, and to have employers being willing to take on students, making sure that vocational qualifications reflect real labour market demand. Finally, both learning in school and work form a package (and align vocational theory and practice). The right mix will depending on the nature of the VET programme and the target destination, and student population.

\section{WBL is routinely integrated in school-based VET across the OECD}

\section{VET systems differ across countries}

50. VET programmes prepare participants for direct entry into specific occupations without further training. Successful completion of such programmes leads to a vocational or technical qualification that is relevant to the labour market. The shape that VET programmes take, and their size, is dependent on the context of labour market regulation and the structure of the economy. ${ }^{12}$ In some countries, it makes little sense to refer to a single "system" as there are important variation between schools and even sometimes between individual students; in other countries, students can choose between a VET programme that is mostly school-based and others, in which most of the curriculum is delivered in the workplace (Figure 1.4).

51. While in the past, students explicitly chose between an academic programme leading to university study or a vocational programmes directly leading to the labour market, the divide is less marked nowadays, and in most OECD countries, ${ }^{13}$ vocationally-oriented programmes are now also designed to prepare students for further study at the tertiary level (OECD, 2018 $\left.8_{[6]}\right)$ (Box 4.4).

\section{WBL is well integrated in school-based vocational programmes in many countries}

52. In many countries, school-based vocational programmes includes a mandatory work placement with employers (see Figure 3.1 for some country examples based on the responses to the OECD questionnaire sent out). Placements are structured in different ways (see the section below on structuring placements) and are typically between 3 months and 6 months - representing about $20 \%$ of the full VET programme. But sometimes in school-based vocational programmes, WBL is optional. For example, in Israel the majority of vocational students follow entirely school-based programmes (Kuczera, Bastianić and Field, 2018[73]).

\footnotetext{
12 Also whereas many countries have extensive vocational programmes at upper secondary level, other particularly English-speaking countries, tend to postpone such programmes to post-secondary level (OECD, 2010 [1]).

${ }^{13}$ This is particularly the case in the European Union countries: with the exception of Belgium and Hungary, the proportion of VET students enrolled in programmes giving direct access to tertiary education is $50 \%$ or above (European Union, 2016 ${ }_{[128]}$ ).
} 
Table 3.1. The use of WBL in school-based vocational programmes in selected countries

\begin{tabular}{|c|c|c|}
\hline Country & Mandatory & Programme \\
\hline Sweden & Yes & $\begin{array}{l}\text { Required } 15 \text { weeks of work based learning within a } \\
\text { VET programme; }\end{array}$ \\
\hline Finland & Yes & $\begin{array}{l}\text { Mandatory work placement of at least } 6 \text { months } \\
\text { during upper secondary vocational programmes } \\
\text { (about } 20 \% \text { of the programme's duration); }\end{array}$ \\
\hline France & Yes & $\begin{array}{l}\text { At least } 22 \text { weeks of mandatory work placement for } \\
\text { upper secondary VET students; }\end{array}$ \\
\hline Netherlands & Yes & $\begin{array}{l}\text { Students in school-based VET programmes are } \\
\text { required to spend at least } 20 \% \text { of their time in work } \\
\text { placements, with an average around } 30 \% \text {. }\end{array}$ \\
\hline Spain & Yes & 300 hours (out of a total of 18 months to 2 years) \\
\hline England (United Kingdom) & Yes & $\begin{array}{l}\text { A minimum of } 315 \text { hours (or } 20 \% \text { of course } \\
\text { duration) in the new T level qualification }\end{array}$ \\
\hline Australia & No & $\begin{array}{l}\text { Variable according to the juridictions and the } \\
\text { institutions }\end{array}$ \\
\hline Israel & No & $\begin{array}{l}\text { Students can undertake workplace visits as an } \\
\text { option }\end{array}$ \\
\hline
\end{tabular}

Source: Countries responses to OECD questionnaire.

\section{The boundary between mandatory and optional WBL is sometimes blurred}

53. Boundary between mandatory and optional WBL can be blurred. Even if WBL is mandatory in theory, some students may not actually take part in it: those who cannot find a suitable placement can typically pursue an alternative (e.g. practical training in school workshops) so that they can complete their qualification. Understandably, such arrangements are designed to reduce the risk of drop-out, but if too many students pursue such an alternative, work-based learning may lose its mandatory nature in practice $(\mathrm{OECD}$, $\left.2014_{[74]}\right)$.

54. The EU-LFS ad hoc module on young people on the labour market 2016 allows students to identify the type of WBL they have participated in while in vocational upper secondary programmes. Figure 3.1 shows that just around $40 \%$ of school-based VET graduates reported having done a mandatory traineeship within their school-based VET programme, and about 5\%, an optional one. But this OECD average hides important differences between countries. 


\section{Figure 3.1.Vocational students have exposure to the labour market through multiple forms of WBL}

Type of work experience while studying, for 15-34 year-old school-based VET graduates (2016)

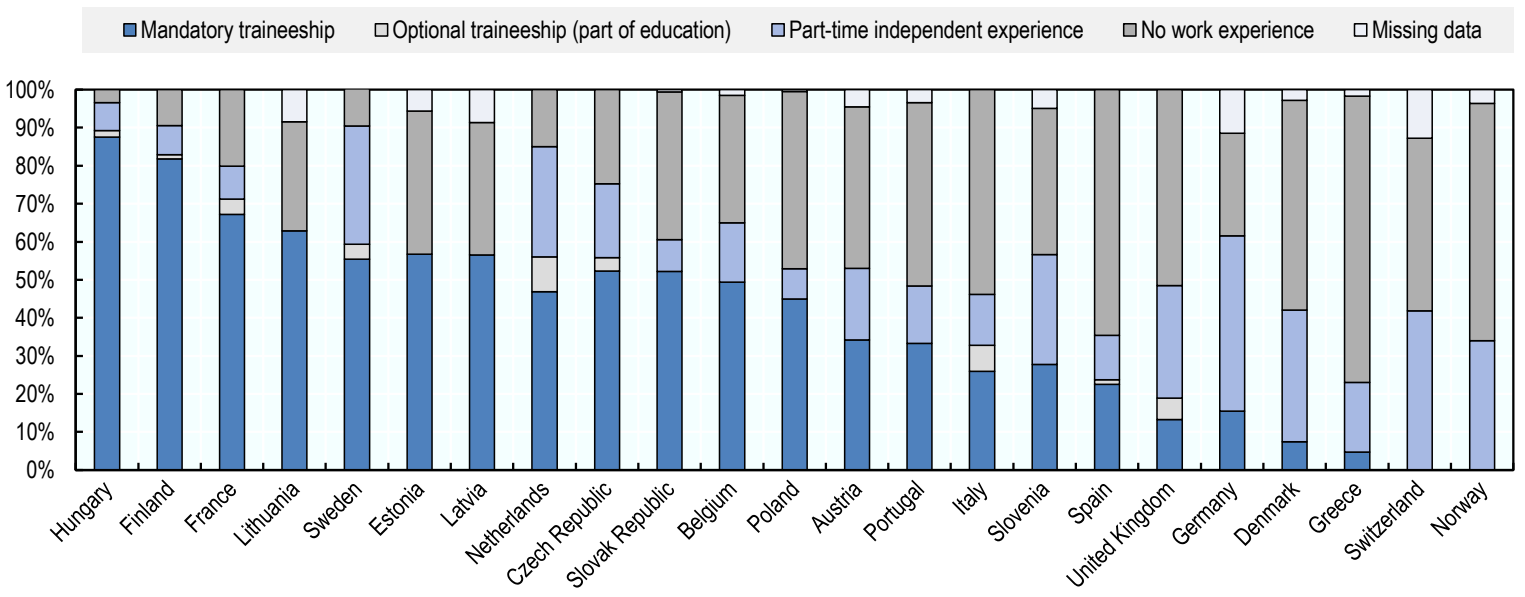

Notes: Apprenticeship, mandatory traineeship, mandatory work-based training and optional traineeship are listed by the dataset as all the mutually excluding categories of WBL. The distinction between apprenticeship and mandatory traineeship is based on duration and payment, and when is not possible to make it, the category of "mandatory work-based training" is used. The category "apprenticeship" is excluded as this study focuses on school-based programmes. The category "mandatory work-based learning" does not include information about the length of the placement, which could be more than 6 months, and therefore, is also excluded from the scope of this study (see Box 1.2 on the LFS definitions). The shares displayed here are the relative shares of the included categories out of all the school-based vocational graduates. The columns do not always add up to one as some countries have missing data in some categories.

Missing data for Iceland and Luxembourg.

Source: Eurostat $\left(2016_{[19]}\right)$, LFS ad hoc modules - Young people on the labour market, https://ec.europa.eu/eurostat/web/lfs/data/database?p p id=NavTreeportletprod WAR NavTreeportletprod I NSTANCE IFjhoVbmPFHt\&p $p \_$lifecycle $=0 \& p \_p \_$state $=$normal $\& p \_p \_$mode $=$view $\& p \_p \_c o l \_i d=$ column$2 \& p \mathrm{p}$ col count $=1$.

\section{Use of school-mediated WBL can also differ within the same system}

55. There can be variations around the use of WBL within the same programme even at a national level. Table 3.1 presents the use of WBL within vocational programmes in Sweden and shows that even though the general principle is that WBL is mandatory in Sweden, there are some cases in which it is optional. 
Table 3.2. An overview of WBL in VET programmes in Sweden

\begin{tabular}{|c|c|c|}
\hline VET programme & & WBL \\
\hline \multirow[t]{3}{*}{ Introductory programmes } & $\begin{array}{l}\text { Vocational } \\
\text { introduction }\end{array}$ & WBL is compulsory but its extent may vary. May be offered as an apprenticeship \\
\hline & $\begin{array}{l}\text { Programme } \\
\text { oriented choice* }\end{array}$ & $\begin{array}{l}\text { WBL is compulsory in programmes preparing for school-based national VET programmes } \\
\text { of apprenticeships (for youth), but its extent may vary. } \\
\text { May be offered as an apprenticeship. }\end{array}$ \\
\hline & $\begin{array}{l}\text { Individual } \\
\text { alternative }\end{array}$ & WBL may be offered and its extent may vary. May be offered as an apprenticeship. \\
\hline $\begin{array}{l}\text { School-based National VET } \\
\text { programmes ( } 3 \text { years) }\end{array}$ & \multicolumn{2}{|c|}{ WBL is mandatory. It covers at least 15 weeks corresponding roughly to $13 \%$ of the programme time. } \\
\hline \multicolumn{2}{|c|}{ School-based VET and apprenticeship for adults } & $\begin{array}{l}\text { WBL is optional within school based VET. However, to obtain state grants, schools must } \\
\text { provide WBL representing: } 15 \% \text { of the study time in school-based VET and } 70 \% \text { of the } \\
\text { study time in apprenticeships. }\end{array}$ \\
\hline \multicolumn{2}{|c|}{$\begin{array}{l}\text { School based VET for students with learning } \\
\text { disabilities ( } 4 \text { years) }\end{array}$} & WBL is mandatory. Minimum 22 weeks of WBL. \\
\hline \multicolumn{2}{|l|}{ Higher VET } & $\begin{array}{l}\text { WBL is mandatory in programmes lasting } 2 \text { years and should represent at least } 25 \% \text { of the } \\
\text { programme time. WBL is not mandatory in 1-year programmes. }\end{array}$ \\
\hline
\end{tabular}

Note: * This programme has recently been reformed. Previously it prepared only for entry on a VET programme. The new programme will lead to all national programmes. Changes are introduced for students who start in autumn 2019.

Source: Ministry of Education (2018[75]), Review of VET in Sweden. Background Report; Skolverket and Refernet Sweden (2016[76]), "Vocational education and training in Europe - Sweden", Cedefop Refernet VET in Europe Reports, https://cumulus.cedefop.europa.eu/files/vetelib/2016/2016 CR SE.pdf.

\section{Making a choice between different types of WBL within VET}

56. However, the benefits of shorter WBL to employers are different from those associated with apprenticeships. Smith and Harris $\left(2000_{[77]}\right)$ remarked at the turn of the century that "the literature on work placements in the VET sector is curiously thin", and the intervening years have not increased the volume significantly. But while apprenticeship provision is not the subject of this study, comparison between it and WBL in school-based VET are useful. Polidano and Tabasso $\left(2014_{[41]}\right)$ identify three main differences which can lead to differences in both employment and learning outcomes. First, the amount of time spent in the workplace during a VET programme is relatively short in school-based provision compared to the time spent as part of an apprenticeship, which has an impact on the outcomes. In Australia for example, among classroom-based upper secondary VET subjects that last a year, those that involve a workplace learning component involve on average 15 days of training in the workplace; compared to at least 96 days of training in the workplace per year for apprentices. Second, unlike an apprenticeship, a WBL component within a school-based programme does not involve an employment or special apprenticeship contract, which means employers may not have the same vested interest to provide quality training.

\section{School-based VET and apprenticeships can be alternative pathways to the same occupation}

57. Apprenticeship and school-based VET can be alternative routes to the same occupation, even if the labour market outcomes are different. This model is common in countries that are trying to expand or build up apprenticeship systems from zero. In Sweden, an upper secondary VET qualification in construction can be acquired through school-based VET programmes for youth, through a youth apprenticeship or through adult VET programmes. Other countries have similar arrangements. In Germany, for example, 
in the healthcare sector, school-based VET, with WBL, is often the dominant form of training, while in many other sectors apprenticeship is more usual. In the Netherlands, there are two vocational routes at upper secondary level leading to the same qualification: apprenticeships with on-the-job time representing at least $60 \%$ of the programme duration, and school-based vocational programmes with mandatory work placements representing at least $20 \%$ of the programme duration. Estonia, Finland and France also offer school-based VET and apprenticeship programmes leading to the same qualifications. Different population groups may prefer one or other route. For example in the Netherlands, the school-based option is more popular with younger students, and in programmes leading to higher level qualifications. In Finland, vocational programmes in schools with short work placements are more popular among young people, while apprenticeships more often serve older students with some work experience. In a system where different paths lead to the same qualification, sideways moves between the paths should, at least in principle, be easy.

\section{Issues arise when school-based VET programmes are offered as a substitute for apprenticeships}

58. School-based VET programmes are sometimes offered as a substitute for those who cannot find apprenticeships. This is the case in Denmark where students who are not able to secure an apprenticeship place with an employer are provided with school-based practical training as a substitute. It is also the case of Norway and Germany. Outcomes, reflected in employment rates, are (unsurprisingly) poorer for this type of programme than is the case with apprenticeships. It can be expected that these findings reflect the characteristics of students who were unsuccessful in finding an apprenticeship. In some cases, school-based VET programmes are held in lower esteem by both students and employers, probably because it is seen as a path for those who failed to secure training with employers in the first place (Helms Jørgensen, 2014 $[78]$; Kis, 2016 [79]).

\section{The balance between WBL and school-based learning will depend of the nature of the VET programmes, its target destination and student population}

59. There are some trade-offs between giving time to WBL and school-based subjects, including general ones. At one end of the spectrum, in some VET programmes, especially apprenticeships, there is a rather small element of general education courses, as part of the (typically) one or one and a half days a week part-time school element - although this varies greatly between countries. This very different curriculum puts students on a learning and career trajectory from which it is subsequently hard to transition out of (Sund, 2013 [80]; Hanushek, Woessmann and Zhang, 2011 $\left.{ }_{[81]}\right)$. But there are also differences within the apprenticeship programmes, on the amount of general subjects, as well as the level of such subjects. In Germany, apprentices must study general education subjects that can include German, other languages, and social studies. At the other end of the spectrum, some students in school-based vocational programmes have a full programme of numeracy and literacy teaching, and similar core requirements to their counterparts in general education. In Finland all upper secondary vocational programmes include: nine compulsory general education subjects that account for around a quarter of the total time; compulsory vocational subjects amounting to 90 credits; and 10 credits of free-choice subjects. All vocational programmes include at least 20 credits of compulsory on-the-job learning (European Training Foundation, 2012 ${ }_{[56]}$ ). In countries where vocational programmes are also designed to prepare students for the tertiary level, there is usually more general subjects included in the VET programmes. In France for example, all those who pursue VET pathways are formally eligible for higher education, assuming success in the 
school-leaving exam academically. While this has the advantage of opening the door to higher education and increasing the attractiveness of provision, it may create other difficulties because of the academic burden (Field and Guez, 2018 ${ }_{[82]}$ ).

60. In many countries, VET graduates can - and many do - continue to study to higher levels. Figure 3.2 displays the percentage of students in tertiary education from vocational programmes (more precisely, the share of students enrolled in tertiary education who are graduates from upper- and post-secondary non-tertiary vocational programmes), and it shows that, on average among OECD countries, one-fifth of tertiary education students come from upper secondary or post-secondary non-tertiary vocational programmes. In some countries, such as the Czech Republic (47\%) and Slovenia (44\%), this share reaches close to one-half of the total enrolled students. The characteristics of VET in these countries may also be different from those in which few vocational graduates enter tertiary education (OECD, 2014 $[74])$.

Figure 3.2. Vocational graduates enter tertiary programmes in some countries

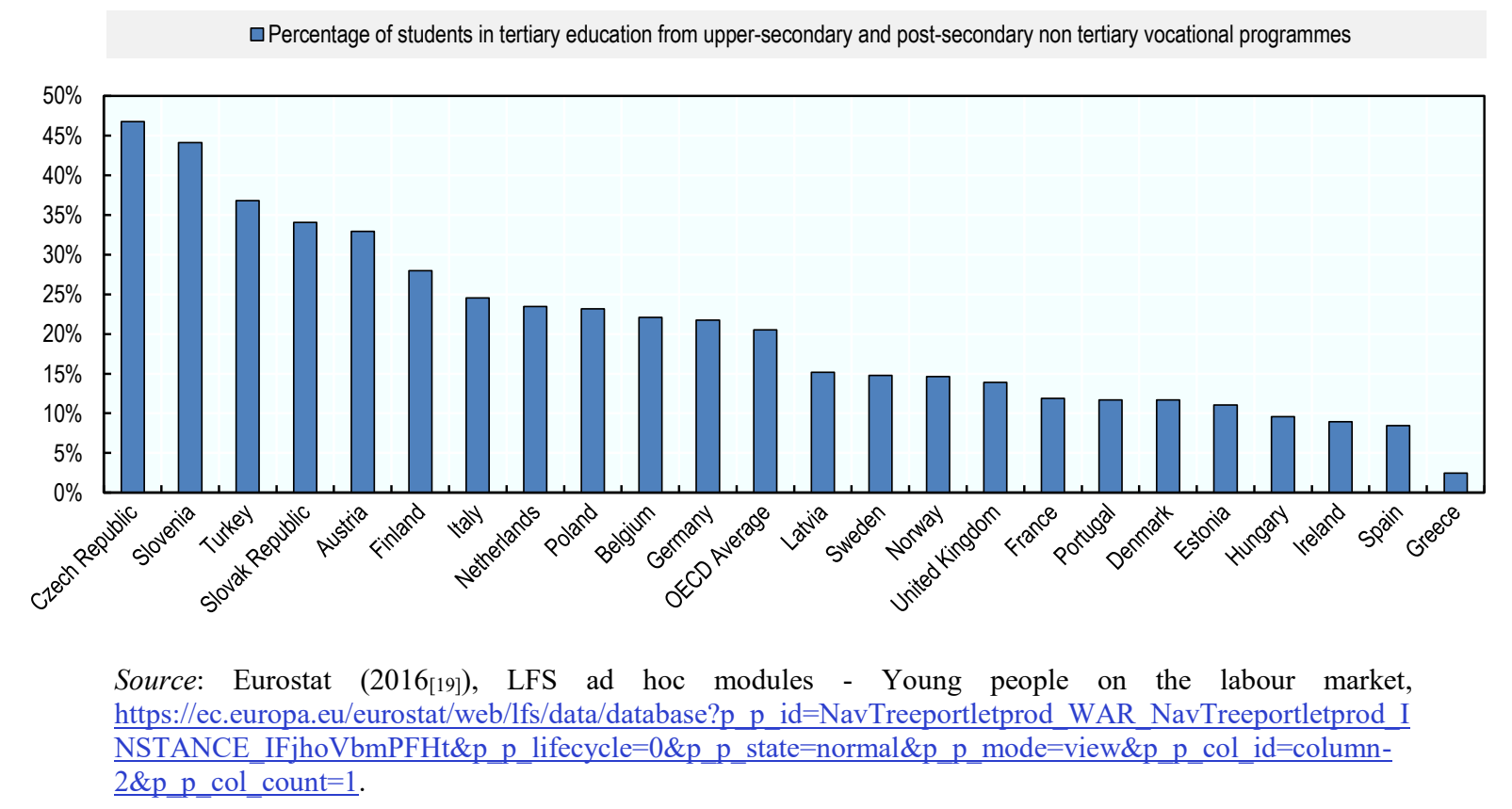

So in the design of a school-based programmes, and in the definition of the mandatory WBL period, a first step is to decide what needs to be included in the total package of learning: for example, what will be the balance between specific vocational skills, vocational theory, general education and personal development? What will be the best combination of time spent at work and time spent in the classroom? (European Training Foundation, 2012[56] $)$. These choices will also depend on the target population for the programmes and/or the occupation. 


\section{Box 3.1. Countries organise the transition between upper secondary VET and higher education in different ways}

From the beginning, the EUX hybrid programme in Denmark combines a three-year Gymnasium education and a four-year apprenticeship within a single programme. EUX is normally four years and a few months in length, with some variability between fields of study. It is a demanding programme, since the students must follow two curricula, so it will only become a small part of the Danish VET system (2\% of students in 2013-14) (Jørgensen, 2012[83]). In 2016, EUX was offered in 39 VET programmes (Aarkrog, $\left.2019_{[84]}\right)$.

Switzerland has a similar programme, by which upper secondary VET students can pursue a general education qualifications which grants access to universities of applied science, in parallel to, or after their regular upper secondary VET programme (Fazekas and Field, $\left.2013_{[85]}\right)$.

Source: Aarkrog, V. (2019[84]), The Interrelation of General Education and VET: Understandings, Functions, and Pedagogy; Fazekas, M. and S. Field (2013[85]), A Skills beyond School Review of Switzerland, OECD Reviews of Vocational Education and Training, https://dx.doi.org/10.1787/9789264062665-en; Jørgensen, C. (2012[83]), Recent Innovations in VET in Denmark. Responses to Key Challenges for VET, http://nordvet.dk/indhold/uploads/report1c_dk.pdf.

\section{Policy messages}

\section{The OECD encourages school-mediated WBL to be mandatory in all vocational programmes}

61. For two reasons, the OECD has strongly encouraged mandatory WBL within all school-based vocational programmes at the upper secondary level (see (OECD, 2014[74]). The first, obvious reason is that the workplace is such a powerful learning environment. But the second, less obvious, reason is that mandatory WBL shifts the whole mind-set of training and education providers, so that partnership with employers becomes essential, rather than an optional extra. It also means overcoming a natural resistance on the part of classroom teachers to the idea that students can learn much in the workplace that they cannot learn so readily in the classroom. So educational institutions and employers naturally need strong incentives to establish partnerships to ensure efficacy and quality of WBL elements in programmes. Some employers may believe (often wrongly) that offering work placements is an unnecessary cost, that they can reasonably avoid, while still benefiting by recruiting from the graduates of a vocational programme. Making work placements mandatory means that programmes can only run when education institutions develop and maintain the active partnerships that support work placements. It allows to make the content of the programmes more relevant for the labour market (OECD, 2014 [74]). Clearly such arrangements cannot be implemented overnight, and asn mentioned before, in some cases the boundaries between mandatory and option can be blurred, and some exemptions, and/or alternative arrangements could be granted. Spain's experience showed that it takes time for employers to learn how to make use of students in work placement and to appreciate and realise the benefits to them of offering such placements (Field, Kis and Kuczera, 2012 $\left.{ }_{[86]}\right)$. 


\section{Make sure that qualifications and curricula to which programmes relate reflect real labour market demand}

62. In the main, employers will be interested in offering work placements in the context of vocational programmes that reflect their business needs. This means that the programmes themselves in which WBL are integrated need to reflect employers' labour market needs. As mentioned in the previous section, WBL allows to make the content of the programmes more relevant for the labour market. Underlying the issue of work placements, qualifications and curricula therefore need to be designed with employers to meet their needs. Sometimes this is a challenge because programmes are designed to be marketed to students, rather than to employers $\left(\mathrm{OECD}, 2014_{[74]}\right)$. The strong engagement of employers, as well as other social partners, in the governance of VET provision is an important means of ensuring the relevance of provision (Bergseng, 2019 ${ }_{[87]}$ ). Relevance for employers can be enhanced through adapting a proportion of the curriculum associated with a national VET qualification to meet local needs. For example in Romania, within the frame of a nationally determined vocational qualification in post-secondary vocational schools, $15 \%$ of the curriculum is agreed locally in consultation with the social partners, subject to endorsement by the school inspectorate (Musset, 2014 $4_{[88]}$ ).

\section{Within school-based vocational programmes, make sure that both learning in school and work form a package}

63. WBL and other forms of learning form a package within a school-based vocational programme. Theoretical vocational theory - for example a baker needs to understand how yeast works and an electrician needs to understand the physics of electricity - and practical vocational skills - how to bake bread, or re-wiring a house - go together (OECD, 2010 [1]). In vocational programmes, learning in the workplace is complemented not only by vocational theory, but also by broader general education, and personal development. Transferable generic basic skills, such as numeracy and literacy, underpin a student's capacity to learn new skills, and transferable "soft" skills, such as team-work, communication skills, flexibility, are valued by employers (OECD, 2014[74]). This means that for policy makers and social partners, the policy question about how to integrate and coordinate the learning that occurs at work and in classroom is essential, both when thinking of creating new work-based learning arrangements and when trying to improve existing ones (European Training Foundation, 2012 $[56]$ ). The balance between the components of the programmes (between WBL, vocational subjects and general education ones) will depend of the purpose of the programme and its target student population (see Box 3.2 about WBL in upper secondary and post-secondary VET programmes in France). 


\section{Box 3.2. WBL in vocational programmes in France}

Students preparing for the professional upper secondary leaving certificate (baccalauréat professionnel), follow a three year programme that must include 22 weeks of WBL. Students can participate in up to six work placements with each placement being a minimum of three weeks. There is a strong focus on integrating school based learning within the job training periods. For instance, the qualification standards define which competences are to be acquired through the on-the-job training. Finding an employer for the student is the responsibility of the VET provider, and VET teachers have to identify and co-operate with companies that are most suitable to host their students. Students sign a training agreement (convention de stage) with the school and the employer, covering working time, health and safety or insurance but also the pedagogical aspects. Use of such documentation enables learners to observe, interact and reflect on what they have learnt and on the activities carried out during the training period. In addition, employers have a key role to play in the preparation phase before the training commences. Teaching staff together with employers define the practical aspects of the training period and determine the tasks the learner is required to carry out. To ensure learners are appropriately supported, support is provided by qualified mentors.

Two-year DUT (Diplôme universitaire de technologie) programmes were launched in 1966 to provide mid-level skills and 120000 students now study for the DUT. They are delivered by instituts universitaires de technologie (IUTS), which are often closely linked to a university. The programmes for each DUT specialty are worked out by national pedagogical commissions including employers, practicing professionals, teaching faculty, and officials from the Ministry of Higher Education and Research. DUT programmes have to include a work placement. Around $40 \%$ of first year students obtain a work placement and $90 \%$ of those in the second year. Placements usually last less than two months in the first year, but in the second year three quarters last two months or more. Three-quarters of DUT graduates continue their studies on graduation.

More than 240000 students are enrolled in post-secondary Brevet de Technicien Supérieur (BTS), programmes. In most cases it is pursued in a lycée professionnelle over a two year period. BTS programmes are in around 100 occupational fields, with some concentration on jobs in the service sector. The content of the training in each field is developed by an advisory committee including employers, employees and government. The BTS curriculum is built on a common base of vocational, technological, and general skills deemed essential for successful performance in a given occupation. BTS candidates spend 14 to 18 weeks each year in internships coordinated by a faculty tutor. The institutions that offer BTS programmes organize practical training opportunities in cooperation with the businesses that are also potential future employers for BTS graduates.

Source: European Commission (2013[60]), Work-based Learning in Europe: Practices and Policy Pointers, http://ec.europa.eu/dgs/education_culture/repository/education/policy/vocational-policy/doc/alliance/workbased-learning-in-europe en.pdf; Field, S. and A. Guez (2018[82]), Pathways of Progression: Linking Technical and Vocational Education and Training with Post-secondary Education, http://www.unesco.org/new/fileadmin/MULTIMEDIA/FIELD/Beirut/images/Education/LinkingTVETHED.p df. 
Box 3.3. Summary of the policy messages

- Make school-mediated WBL mandatory in all school-based vocational programmes.

- Make sure that qualifications and curricula to which programmes relate reflect real labour market demand.

- Within a school-based vocational programmes, make sure that both learning in school and work form a package (and align vocational theory and practice). The right mix will depending on the nature of the VET programme and the target destination, and student population. 


\section{Chapter 4. Realising the benefits of WBL}

Challenges for realising the benefits of WBL include engaging employers, promoting equitable access, connecting learning at work and in school, and structuring placements. This chapter, for both general education and vocational programmes, analyses the implications of these challenges, and distils some policy messages.

64. Both general education and vocational programmes face common challenges in engaging employers, promoting equitable access to WBL, connecting learning at school and at work, and structuring placements. The policy options can also be common, although there will be some nuances on how the policy can be adapted, based on the national context and the type of programmes.

\section{Engaging employers}

\section{Engaging employers can be challenging}

65. Often, one of the main actual or perceived barriers to effective WBL is that employers are reluctant to offer work placements, or else offer inadequate placements. For example in the United Kingdom, $66 \%$ of employers say work experience is an significant factor in their recruitment practice, but only about $20 \%$ of them offer work placements to upper secondary schools - and $12 \%$ to further education institutions which typically offer school-based VET alongside general education programmes (UKCES, 2015 $5_{[48]}$ ). Between countries, there are marked disparities in the number of employers involved in the provision of WBL opportunities and in the incidence of organised WBL for employees. In addition to the geographical dimension, the incidence of WBL also varies across sectors and company size (European Training Foundation, 2012 ${ }_{[56]}$ ).

66. Employer reluctance often stems from two sources: one is that they find it too burdensome to take on trainees (sometimes because of the quality assurance requirements described later), the other more importantly is that they do not believe that they will benefit significantly. There also may also be trade-offs for employers between offering apprenticeships and shorter placements for VET students, as well as internships for higher education students (Box 4.3).

\section{Work placements need to deliver benefits to employers}

67. The most effective way of engaging employers is to ensure that WBL has substantial benefits to them. Drawing on the theory outlined in Kis $\left(2016_{[89]}\right)$, Hoftijzer, Stronkowski and Rozenbaum, $\left(2018_{[90]}\right)$ suggest some ways in which the productive contribution of trainees might be increased, as a means of encouraging WBL in Poland (Box 4.1). 


\section{Box 4.1. Increasing the productive benefits of WBL in Świętokrzyskie, Poland}

A World Bank study of Świętokrzyskie, Poland, found that employers offering vocational placements tended not to engage WBL-students in actual production activities. Instead, firms currently see the benefits of WBL as a means of recruiting students in areas of skills shortage. Even when the direct production benefits of WBL are not firms' main reason to engage in WBL, the World Bank report argues that engaging students in production processes would still be very helpful for two reasons. First, their engagement in actual productive work would be one of the best ways of developing their skills. Second, the benefits arising from their productive contribution would increase firms' willingness to engage in WBL by its impact on the cost-benefit ratio. To achieve this positive outcome, the World Bank report proposes the following measures:

- Extending the duration of WBL over and above the mandatory four weeks of traineeship so that students can develop their skills and make a stronger contribution to production at the end of the period.

- Second, support measures to help firms integrate students into production processes.

- Third, further capacity building, tools development and financial incentives for employers.

- Fourth, addressing safety issues involved for students working in heavy industry.

Source: Hoftijzer, M. et al. (2018[90]), Getting Out of School and into the Workplace: Strengthening Work-Based Learning in Upper Secondary Technical Education in Poland's Swietokrzyskie Region, https://dx.doi.org/10.1596/978-1-4648-1322-1

\section{Financial incentives for employers offering WBL might have limited effects}

68. One way of encouraging employers to take trainees is to offer financial incentives ${ }^{14}$ but these are used only occasionally in the context of school-based vocational and general education programmes. Incentives to employers taking apprentices are much more common, but here the evidence suggests that incentives have only a modest effect (Kuczera, 2017 ${ }_{[91]}$ ). Often this is due to the large amount of "deadweight" (employers would have taken on the apprentices without the incentive). Moreover, financial incentives - particularly large incentives - may distort the offer if employers who are not fundamentally interested in the training take trainees simply because of the incentives, then the end result is unlikely to be quality WBL and may distort labour market signalling. The way that the funding arrangements are designed can also cause issues: in Australia for example, funding is not available for employers providing work placement for secondary students. This has led to some inconsistency between the provision of work placements for secondary students and other government programmes i.e. the National Work Experience Programme, where employers are paid AUD 300 to host a student in the case of the Catholic school sector (National Catholic Education Commission, 2018 ${ }_{[92]}$ ).

14 Options can include: discounting training wages for learners' lower productivity; government subsidies, tax relief, relief from social payments; a national training tax for firms that do not provide training (European Training Foundation, 2018 ${ }_{[67]}$ ). 


\section{Non-financial incentives can be useful}

69. Despite all the theoretical benefits, it can be difficult to convince employers to offer such placements. They might still consider it too much of a burden to take on trainees and they might not believe that they will benefit significantly. This may apply even more to secondary school students, as they might be "competing" for work placements with higher education students, and employers might prefer to choose students who are perceived (perhaps wrongly) as more mature, reliable and productive.

70. A number of organisations, notably employers' chambers and small business associations, can help enterprises to deliver work-based learning (particularly small and medium-sized enterprises that do not have specialist training staff). Local programme management committees that include employers, educational institutions and social partners can help to improve cooperation and communication between schools and enterprises about training, for example by facilitating the access of teachers to enterprises (European Training Foundation, 2018[67]).

71. In New Zealand for example, the national Industry Training Federation organises "speed dating" events in which employers offering work placements meet prospective students (about seven at a time) and make their choice. In Sweden, secondary schools organise group internships for students with the same employer, as these are seen as easier to organise for schools and more attractive to employers (stronger and more mature students can support less abled ones). (Industry Training Federation, $2019_{[93]}$ ).

\section{Intermediary organisations can help support enterprises with WBL}

72. Intermediary organisations such as employers' chambers, trade associations, and small business associations, can also do a great deal to help enterprises to improve the quality of work-based learning. These organisations can be particularly helpful to SMEs (Small to Medium Enterprises) that lack formal training expertise. In the case of apprenticeships, Australian Group Training companies, the regional centres of expertise found in the Netherlands, and Norway's local training offices are other examples of independent organisations that support employers to deliver high quality work-based learning, by liaising between employers, education and training providers and governmental authorities, but there is no reason why similar structures could not provide them same support in the case of shorter WBL. All have been created as the result of government policy initiatives (European Training Foundation, 2018 ${ }_{[67]}$ ).

\section{Local partnerships are important to facilitate WBL}

73. One important key precondition of effective WBL is local partnerships between secondary schools and the employers that provide the WBL. Such partnerships facilitate the initial offer of work placements, and the subsequent exchanges between schools and training employers. Such communication sustains work placements and ensures that the placements fit effectively into the vocational programme. In Australia, local industry-school partnerships have been increasingly recognised as a means of preparing students for employment through access to resources that are beyond the financial capacity of schools (Flynn, Pillay and Watters, 2014 ${ }_{[94]}$ ). 


\section{Schools may need support to learn how best to work with employers in developing $W B L$}

74. Individual schools may need support in developing links with employers and their capacity to foster WBL. The European Training Foundation has put together a very useful handbook for stakeholders to identify barriers, and solutions, related to WBL (European Training Foundation, 2018 $\left.8_{[67]}\right)$. Sometimes this support may come from organised bodies, such as the SBB in the Netherlands (Box 4.5). Employers' chambers, small business associations and similar organisations have the advantage of being closer to the daily requirements of running a business than schools and colleges, and so may find it easier to approach firms and offer them advice and assistance with work-based learning. An advantage of intermediaries is that they can approach employers on behalf of multiple schools. This avoids employers being inundated with requests for support and reduces the burden on schools. Governments can introduce policies to provide resources to these organisations to allow them to support work-based learning (European Training Foundation, 2018 $\left.8_{[67]}\right)$. It will often also be helpful for schools to find means to share their experiences. One systematic support for this form of sharing is provided in Finland in the shape of a manual, developed by the Finnish National Board of Education (Box 4.2).

\section{Box 4.2. Transferring innovative models of work-based learning in Finland}

The Finnish National Board of Education along with identified partners, published a manual for transferring innovative work-based learning practices, designed to help VET providers and stakeholders unsure of how to select, and make use of, the most appropriate model of WBL. It is targeted at different audiences including VET providers, colleges, training centres and employers. The manual focuses on the process of transformation and innovation of VET programmes and WBL practices. It encourages VET providers to carry out a needs assessment, using measures such as a SWOT analysis and peer review, to identify what needs improvement. It encourages providers to identify good practice in other providers by identifying those aspects that are not context dependent and can be transferred. The manual also offers practical examples of how VET schools can identify where improvements to WBL are required, how to plan to make such improvements and how to deal with changes that have been made.

Source: European Commission (2013[60]), Work-based Learning in Europe: Practices and Policy Pointers, http://ec.europa.eu/dgs/education culture/repository/education/policy/vocational-policy/doc/alliance/workbased-learning-in-europe en.pdf.

\section{Flexible arrangements are attractive for employers}

75. Polesel et al. (2016[95]), through a survey of secondary schools in Australia, found that most schools were able to form partnerships with employers, but that carefully documented processes and flexibility were required to integrate WBL sequences into school programmes successfully. Interestingly, the study also found that businesses were more likely to see the mutual benefits of providing work placements and engaging with students if they were given a greater role in the schools' decision-making regarding the organisation of the programmes. This confirms that programme design and demand - in relation to both general and especially vocational courses of study - which schools select influence the prospect of forming successful partnerships with industry. This also reflects another tension between the perceived needs of school and industry. In terms of 
implementation, a successful partnership necessarily requires the ceding of some school autonomy - in the decisions as to what programmes should be offered and how the partnership and its constituent elements of work placement and timetabling should be organised. Greater school autonomy requires the right accountability and support measures for institutions to support them with work-based learning (European Training Foundation, $\left.2018_{[67]}\right)$.

\section{Make the employers aware of the possibilities to engage}

76. As mentioned before, employers take part in WBL programmes for a number of reasons. If they are to participate, employers need to be aware of programmes and their benefits. This highlights the importance of awareness raising, marketing and communication and the engagement of employers more broadly in educational provision (European Training Foundation, 2012 $[56]$ ). In order to engage employers more strongly in WBL, it is important to make the business case to employers and employees to demonstrate how they would benefit from participating - since the direct benefits may be limited (during short placements, students do not typically do productive work). More than that, it needs to be easy for employers to engage. This can be achieved by helping employers to understand what schools are looking for in terms of work placements, and the characteristics of students by enabling close collaboration.

\section{Box 4.3. Approaches to health and safety}

United Kingdom: According to UK Government guidance rules for industry placements, to provide a safe work environment is the sole responsibility of the employer. Employers are also responsible for making sure, in health and safety terms, that "students are ready for their industry placement" (GOV.UK, 2019 $\left.{ }_{[96]}\right)$. Indeed, the Health and Safety Executive underlines that employers should manage the risks in their workplace, and hence should be the ones deciding whether they need to implement additional precautions when providing a placement for a young person (Health and Safety Executive, 2019 [97] $)$. As a consequence, schools should accept employers' risk assessments and not second guess them. It is recognised that employers can have a tendency to go beyond legal requirements in terms of health and safety and it is important that clear, relevant guidance is easily available to help manage expectations.

New Zealand: Following the Health and Safety at Work Act of 2015, the Board of trustees/Host employer is responsible for ensuring the health and safety of their workers while at work (Ministry of Education, 2016 $6_{[98]}$ ). More precisely, students are to be considered as workers when undertaking a work experience at a particular enterprise. Thus, the employer has the "primary duty care" and needs to provide not only a safe and healthy work environment, but also the right information and training to all workers. On the other hand students have to take reasonable care of their own health and safety in what they do, cooperating with policies and instruction received on the workplace.

Source: GOV.UK (2019[96]), Guidance - Industry placements, https://www.gov.uk/guidance/industryplacements; Health and Safety Executive (2019[97]), Work experience, http://www.hse.gov.uk/youngpeople/workexperience/index.htm; Ministry of Education (2016[98]), Students on Work Experience - A Health and Safety Guide for Schools and Employers, https://www.education.govt.nz/assets/Uploads/SES-Students-on-Work-Experience-HS.PDF. 


\section{Policy messages}

- Intermediary organisations can help support enterprises with WBL.

- Local partnerships are important to facilitate WBL.

- Schools may need support to learn how best to work with employers in developing WBL.

- Flexible arrangements are attractive for employers.

- Make sure that employers are aware of the possibilities to engage.

\section{Promoting equitable access for students}

\section{It is sometimes hard for at-risk students to obtain work placements}

77. Work-based learning involves two major equity challenges. First, employers normally choose their trainees. This means that, other things being equal, students with weak grades or behavioural challenges that are evident to employers may find it very hard to find placements. Employers will have particular concerns about permitting disengaged students to work with expensive equipment and materials or interact with valued clients. Migrant students struggle more than native-students in securing work placements (Jeon, $2019_{[99]}$ ). Employers may also display discriminatory behaviour. Students will have special challenges in economically depressed regions, where there are fewer workplaces willing to offer placements. Second, if students have to find their own work placements then students from advantaged backgrounds might have access to opportunities that are more enticing, through their parents' professional networks for example. Similarly equity concerns arise about internships in higher education programmes (Box 4.4).

\section{Box 4.4. Work placements in higher education}

While many of the theoretical benefits of WBL remain unchanged in higher level programmes, such programmes sometimes raise different practical issues. In universities, the academic culture is sometimes at odds with the need to partner with employers to deliver effective WBL, although universities of applied science and some post-secondary technical colleges may be better placed in this respect. One model is the "sandwich" degree, in which, typically, a year of work placement is sandwiched between two periods of academic study. Work placements also need to be structured around university terms and timetables.

For example, surveys of employers in the United Kingdom provide evidence in favour of the notion that work experience during higher education is helpful for securing employment upon graduation (UKCES, 2015 $[100])$. Similar results are reported by Blasko, Little and Woodley $\left(2002_{[101]}\right)$, who looked at British tertiary graduates in the mid-1990s. They find that work experience during university, in particular study-related work experience, positively affects employment outcomes and entry salaries.

Particular equity challenges arise in "internships", which have emerged as an increasingly important element of the job market in many countries. While the internship terminology is applied variously, usually it means an unpaid or a lowly paid period of work experience with an employer, often of a few months, which may be an official or unofficial component of undergraduate study, but may also be independent of school or college programmes. 
Jacobson and Shade $\left(2018_{[102]}\right)$ offer a classification of these different types of internship. One definition of internships is "structured, supervised, and short-term programmes in which undergraduate or graduate students perform tasks and duties within an organisation in order to gain knowledge and experience. The student may or may not earn monetary compensation from the company and/or academic credit from the university" (Grasgreen, $\left.2012_{[103]}\right)$. There is some positive evidence suggesting that work placements linked to college programmes, can improve academic outcomes and help to crystallise career choices. Such placements also seem to improve employability at least in the short run, with long term impacts less clear. There is much to suggest that the design of internships - such as the type of mentoring received, the extent to which interns perform meaningful tasks, and whether they are paid - bear heavily on outcomes, but little hard research evidence is available (Hora, Wolfgram and Thompson, $2017_{[104]}$ ). There is an active debate about whether interns are exploited as unpaid or cheap labour. (According to one survey, only about one-third of interns in the United States receive any pay) (Grasgreen, 2012 ${ }_{[103]}$ ). While these programmes can, if well handled, yield very valuable forms of WBL, they can also raise equity concerns when recruitment occurs through word of mouth.

Source: Blasko, Z., B. Little and A. Woodley (2002[101]), UK graduates and the impact of work experience, https://dera.ioe.ac.uk/5171/1/rd17 02.pdf; Grasgreen, A. (2012[103]), "Resume-builder or rip-off", Inside Higher Ed. February, 2012, http://www.insidehighered.com/news/2012/02/03/growth-short-term-internshipsover-academic-breaks; Hora, M., M. Wolfgram and S. Thompson (2017[104]), "What do we know about the impact of internships on student outcomes? Results from a preliminary review of the scholarly and practitioner literatures", CCWT Research Brief no. 2., http://ccwt.wceruw.org/documents/CCWT-report-DesigningInternship-Programs.pdf; Jacobson, J. and L. Shade (2018 [102]), "Stringtern: springboarding or stringing along young interns' careers?", Journal of Education and Work, Vol.31/3, pp. 320-337, http://dx.doi.org/10.1080/13639080.2018.1473559; UKCES (2015[100]), Employer Skills Survey 2015 of 91000 Employers.

\section{Work placement choice might exacerbate equity concerns}

78. WBL typically provides students with their first significant encounters with the world of work. Gender and socio-economic status have an influence on students' aspirations, and such patterns also have an impact on both the access and the choice of work placements. In England (United Kingdom), analysis of national survey data of 13421 students aged 15 and 16 year old found that students from minority ethnic background were significantly less likely to have completed school-mediated WBL ${ }^{15}$ (Archer, Dewitt and Osborne, $\left.2015_{[105]}\right)$. Most students who had undertaken a work placement reported that it had been organised through family and friends. This means that those from disadvantaged backgrounds may be less likely to access a range of quality placements. This is confirmed by other sources that show that in England typically half or more of secondary school students have found their own work experience (Francis et al., $\left.2005_{[106]}\right)$. Young people from more privileged backgrounds more often enjoy personal and family connections linked to better paying, higher status professions, and are more adept at finding the most meaningful work-based learning opportunities. This means that those from more privileged

${ }^{15}$ Also, students aspiring to medicine, science and engineering were among the least likely to have completed work experience. Most likely to have completed work experience were those aspiring to become teachers, tradespeople or work in business. Finally, students planning on taking A levels were significantly less likely to report having completed work experience compared to those planning on entering work or apprenticeships after GCSEs. Those who had completed work placements valued the experience gained, with some saying that it hadagai influenced their post-16 plans. 
backgrounds are in a strong position to obtain the most advantageous work placements. Comparing the type of placements undertaken by students in schools of different levels of affluence in England (United Kingdom), Le Gallais and Hatcher $\left(2014_{[107]}\right)$ found that in low socio-economic status schools, one-quarter of students undertook placement in the retail sector, while in more affluent schools, placements were more commonly in managerial and professional workplaces.

79. Studies show that work placements are strongly segregated by gender for secondary school students in England (United Kingdom) (Equal Opportunities Commission, $\left.2005_{[108]}\right)$. Only $15 \%$ of students said that they had received specific guidance about nontraditional placements (Osgood, Francis and Archer, 2006 $\left.{ }_{[109]}\right)$, yet significant numbers of young people indicated interest in trying such a placement. Gender stereotypes can be mitigated through school-mediated WBL in non-traditional occupations.

\section{Collect data about students and their placements}

80. Schools' social and culture capital shapes greatly the opportunities available to students. As mentioned before, there are strong arguments for ensuring that disadvantaged students can access quality WBL opportunities. Collecting information and data about schools, students and their placements allows to identify schools that might have more difficulties in ensuring that their students have access to WBL, and perhaps target more resources to their schools. Intermediary bodies operating on a local or sub-regional basis can enable such a process, as discussed in Chapter 4.

\section{Equity challenges can be mitigated by open competitions for work placements}

81. One answer to equity challenges within WBL is to give vocational providers a leading role in identifying work placements and matching them up with trainees. This role can, in turn, be supported by websites on which work placements are openly advertised, and indeed through requirements that they be openly advertised. These measures help to mitigate, if not remove, the equity risks involved in finding work placements by word of mouth. One example of this is the nationwide website advertising work placements for school-based VET in the Netherlands (StageMarket, 2019 [110]). These measures do not remove the role of the employer, who will still make the final choice of which trainee to take. Other useful practices include helping students in the search for work placements (help with writing their $\mathrm{CV}$, training on interview techniques, etc.). Such job-search methods, in combination with interventions to give the proper skills to young people, amongst other activation mechanisms, have a positive impact on labour market insertion (OECD, 2015 $[111]$ ).

\section{$W B L$ represents a real opportunity to re-engage disconnected young people, which can be given extra support}

82. Set against these challenges are some real opportunities for disadvantaged students. WBL has many potential attractions for such students who can see classrooms as domains of threat and failure. Importantly, it offers the opportunity to perform and excel in more practical contexts. One approach is to develop work-based programmes targeted specifically at those who are at risk. In Germany, 'transition' pre-apprenticeship programmes help prepare learners, often including migrants, who struggle to find employers willing to take them on as apprentices (Bergseng, Degler and Lüthi, 2019 [112]). Most jurisdictions in Australia offer students some types of preparation courses before the work placements - which makes sure that they are better prepared when they start WBL 
(Musset, forthcoming $\left.{ }_{[8]}\right]$. Sweden offers group internships for secondary school students, wherein weak students are paired up with stronger (and more mature) ones, making it more attractive to employers to engage and offer placements. In the United States, at local level, different WBL initiatives have proved very effective in re-integrating disconnected youth (Box 4.5).

\section{Box 4.5. Innovative approaches using WBL to engage youth at risk in the United States}

The " 12 for Life Programme" places at-risk students in real jobs in Southwire, a company, allowing them to earn wages while earning credit toward a diploma. The programme combines traditional classroom instruction with jobs inside a real manufacturing plant. Students work regular hours, earn wages, and learn valuable skills they will need after they graduate. Southwire employees share their time and experience through a mentoring programme that provides one-on-one support. Students rotate from workstation to workstation, gaining experience throughout the manufacturing process. They learn job skills, including machine operation, logistics, product and reel assembly, shipping, quality assurance and data entry. Guest speakers and tours of various Southwire facilities give students the flavour of the range of jobs available. By mid-2015, more than 1100 students had graduated from 12 for Life. $40 \%$ of graduates went on to post-secondary education, while another $30 \%$ joined the military. Another $20 \%$ went to work for Southwire or other employers.

The "Urban Alliance" initiative, focused on high school seniors in distressed communities, aims to help youth move on to higher education or employment through a high school internship programme. The programme's key components are: 1) paid internship in an office setting (Monday to Thursday after school and full-time during the summer); 2) soft and hard skills job training for four to six weeks after school at the start of the programme, followed by ongoing training after school each Friday; 3) coaching and mentoring provided by Urban Alliance; and 4) alumni services consisting of individual coaching, alumni reunions and events, and a paid internship opportunity during the summer break from college. Interim evaluation results show a positive impact on college attendance among male participants and a positive impact on four-year college attendance among middleperforming students.

Another similar programme is "This Way Ahead", a paid internship programme for lowincome youth. Youth are recruited by a local non-profit that runs a job training programme. Store employees volunteer to lead store tours and skill-building workshops. Youth receive supplemental online training. Those interested may apply for paid internships, working 12 hours per week for 10 weeks. During the internship, participants receive support from nonprofit job coaches, store managers and store colleagues. The programme has offered internships to over 2600 low-income youth. In 2016, over 70\% of interns received job offers upon completing their internships. Participants stay with the company twice as long as their peers and have higher engagement than their colleagues. Evaluations suggest participants improve their confidence and on-the-job skills.

Source: Kis, V. (2016[79]), "Work-based learning for youth at risk: Getting employers on board", OECD Education Working Papers, No.150, https://dx.doi.org/10.1787/5e122a91-en. 


\section{Policy messages}

- Take into account that some students face extra barriers and give them extra support, allowing open competition for work placements and using intermediary bodies to mediate relations between schools and employers.

- Collect data about students and their placements.

- Ensure that students who need it can receive preparation in advance of the placement, and consider options such as group placements.

\section{Connecting learning at school and at work}

83. Work-based learning and classroom-based learning should not be seen as separate activities. They should be treated as part of a complete package: classroom learning complements and adds to learning in the workplace; learning at work complements and adds to learning in the classroom (European Training Foundation, 2012[56]). However, it can be challenging to ensure that students really learn, while leaving enough flexibility to ensure employers are not discouraged from offering placements by overly strict regulation. Tripartite arrangements between the education institution, the students and the employer can help clarify expectations.

\section{Three particular mechanisms underpin quality - accreditation of employers offering placements, preparation of workplace supervisors and measures to link school and workplace}

84. Specific quality assurance mechanisms are used by countries to support the quality of WBL. These mechanisms include: arrangements for accrediting employers as being suitable to provide WBL; measures (often linked to accreditation) to ensure that workplace trainers are trained to look after those on work placement; and measures to integrate WBL with the classroom part of a programme. These three issues are looked at below, and illustrated with country examples. These are approaches essential to the delivery of effective WBL within school-based VET programmes and demand consideration in the design of WBL delivered within general education programmes.

\section{Arrangements are necessary to ensure that employers offering WBL are suitable}

85. One key element in quality assurance is arrangements to ensure that WBL is delivered in workplaces where students have a full opportunity to learn relevant skills. This can be pursued through the registration of employers (sometimes particular sections of large employers) which meet minimum requirements. Essential attributes can relate to the kind of workplace experience and training on offer, whether there is adequate workspace for trainees, and to the forms of support, supervision and feedback which trainees will receive. At its best, such accreditation is not only a control to ensure minimum standards, but also a measure that assists the employer to provide the best quality WBL. This screening can be done by the education institutions or by the social partners. The Dutch and Danish approaches are set out in Box 4.6. 


\section{Box 4.6. Accrediting employers to provide WBL in the Netherlands and in Denmark}

Some of these examples are about apprenticeships but some of the same policy principles can apply for WBL within school-based programmes.

\section{Netherlands}

The Dutch Cooperation Organization for Vocational Education, Training, and the Labour Market (Samenwerkingsorganisatie Beroepsonderwijs Bedrijfsleven, SBB) is a collaboration of VET providers and the private sector, which aims to improve the employability of VET students and align skill supply with demand through work placements. The SBB has a legal mandate to accredit and coach companies offering work placements both for apprenticeship and for the work placements which form a mandatory part of the school-based VET programmes. SBB also maintains the qualification framework for secondary vocational education and provides labour market information. The SBB works on a sector, regional and national level. The SBB's accreditation criteria serve to determine if the quality of the work placement is suitable for appropriate skill acquisition, and if the firm offers a good and safe working and learning environment with appropriate supervision. The accreditation is based on common quality criteria, covering the training opportunities available, the availability of experienced and competent in-house trainers, the capacity to co-operate with the VET school, and the availability of work space for students.

After accreditation, SBB facilitates training provision for in-firm trainers, communication between firms and schools, and knowledge exchanges between companies. Accredited workplaces are registered on an open website, helping students and schools to find work placements. The quality of WBL placements is monitored by education advisers, who regularly visit work places, monitoring as well as providing advice for all key actors in all aspects of work-based learning.

Source: Hoftijzer, Stronkowski and Rozenbaum (2018[90]), Getting Out of School and into the Workplace: Strengthening Work-Based Learning in Upper Secondary Technical Education in Poland's Swietokrzyskie Region, https://dx.doi.org/10.1596/978-1-4648-1322-1.

\section{Denmark}

The Danish approach to assuring the quality of apprenticeship provision provides a model of practice which could be applied to WBL placements in school-based programmes, especially for vocational programmes. Companies providing apprenticeship training have to be approved by the social partners through the relevant trade committee. Employers have to demonstrate they are able to offer various tasks in an occupation and have required technical equipment. Committees may also assess whether the company has the staff available to perform the training. There are different types of trainers with different responsibilities: planners, training managers and daily trainers. Trainers in enterprises who are responsible for apprentices must be craftsmen. They must have completed a VET programme for which they have received a "journeyman's certificate" and have work experience. Accreditation does not need to be renewed unless the company has not been active for five years or more.

Source: Andersen and Kruse $\left(2016_{[113]}\right)$, Vocational Education and Training in Europe - Denmark, http://www.cedefop.europa.eu/en/publications-and-resources/country-reports/denmark-vet-europe-countryreport-2016. 


\section{The training skills of the employees who supervise trainees during $W B L$ are critical}

86. Often the quality of WBL will depend on the kind of support, mentoring, guidance, training and feedback offered to students by the employees who supervise them. This can be a demanding pedagogical task. In Finland, lack of adequate staff in the workplace has been seen as one of the challenge in promoting WBL in SMEs (Virtanen, Tynjälä and Eteläpelto, 2014[114]). While many countries require rather substantial formal training for those who supervise apprentices, it may be unrealistic to expect so much training for those who supervise trainees on work placements. Box 4.7 describes the kind of training that is available to workplace trainers in Sweden. Sometimes, as in Denmark and the Netherlands (Box 4.6), there are common requirements for employers to be accredited to offer both apprenticeships and work placements as part of school-based VET, and the accreditation criteria include expectations that in-firm trainers be appropriately prepared for their task.

87. In Sweden, every work place offering WBL as part of an upper secondary VET programme must have a designated trainer to support and monitor the student's progress during the WBL period. There are no firm training requirements for such designated trainers, but state grants are channelled through schools to provide incentives (maximum SEK 10000 / EUR 960 per year) to employers to train trainers. Grants are also available to social partners providing training for trainers (Kuczera and Jeon, 2019 [115]).

\section{Box 4.7. Online training for workplace trainers in Sweden}

This programme is designed for current and prospective designated trainers in enterprises offering WBL as part of VET programmes, and for VET teachers in schools. It involves the equivalent of two days coursework, and includes four introductory general modules and a supplementary module that covers apprenticeship. Each module contains short video scenes followed by interactive exercises. All theoretical content is presented as animated short films (sketch notes). It can be followed online in a flexible way, whenever and wherever it suits the trainer, and has been developed for different devices, including smartphones and tablet computers. The training is free of charge at the point of use and is funded by the National Agency for Education. As of November 2018, more than 28000 employer-based trainers had completed the programme, as well as 3700 VET teachers, (about half of the total).

Source: Ministry of Education (2018[75]), Review of VET in Sweden. Background Report.

\section{The work-based element of learning needs to be linked effectively to classroom teaching}

88. In the case of vocational programmes, for WBL to be of most value, it needs to be integrated into the broader programme of which it is a part $\left(\right.$ OECD, 2014 $\left.{ }_{[74]}\right)$. This means providing scope for students to apply the theory that they have acquired in the classroom in practical settings, and conversely allowing practical workplace experience to inform classroom learning. This integration is supported when WBL has clear learning objectives and is credit-bearing, as this clarifies the role played by WBL in the vocational programme as a whole. The time-sequencing of WBL is relevant to this process, as it should allow this type of learning iteration to take place. Teachers therefore need to have a close awareness of the nature of work placements (typically acquired by visiting students and employers 
during work placements) so that they can take full advantage of the practical experience of students.

89. Interestingly, a study on WBL in Australia found that employers who give feedback to students on their learning during placement are more likely to perceive students to be work-ready than those who do not offer feedback (Smith, Ferns and Russell, 2014 [47]]).The implication is that employers who guide their trainees end up with better trained trainees.

90. Teachers ensure the quality of the training that takes place in the workplace in Spain (SGOIFP, 2019 $[116]$ ) and in Sweden (National Agency for Education, 2018 $[117]$ ). This puts a lot of responsibility on individual teachers running risks of variability in practice. Safety nets have to be put in place within quality assurance mechanisms. Social partners can play an important role, for example at the regional level, in organising links between employers and VET schools. They can share responsibilities with teachers, helping to organise placements. Teachers need to make regular visits to enterprises, to check on students' progress, pick up any ongoing problems with training and help workplace supervisors to understand what needs to be learned and with the formal assessment of students' learning (European Training Foundation, 2018[67]). These obligations can be problematic if they do not take into account teachers' formal working arrangements, together with the right training programmes. A survey of teachers in nine EU countries found that in some countries, trainers are quite satisfied with the accompanying support provided by the school, but in others, lack of co-operation between vocational teachers and workplace trainers, and between schools and businesses, was reported (Partnership-Project on Workbased Learning and Teaching, 2015[33] $)$.

\section{Students are the common thread linking classroom learning with WBL}

91. A successful work experience placement must achieve a balance between the student's contribution to the workplace where they are doing their placement and their learning requirements. Disappointment on the part of both the employer and student can be avoided if both parties have clear expectations about their respective roles and responsibilities. A "contract" lets all the parties know what is expected of them in advance of the WBL beginning (Canadian Council on Learning (CCL), 2009 ${ }_{[118]}$ ). Students and placements have to be well matched: when students are not interested in the career path associated with a particular placement, they may become disengaged. As a result, employers feel they are wasting scarce resources, and both student and employer become disenchanted by the experience (Canadian Council on Learning (CCL), 2009 $[118]$ ).

92. The common thread, linking classroom learning with WBL, is the student. While students often need supporting mechanisms to sourcing their placement, they themselves need to play a very active role in order to benefit from, and ensure complementarity between, the two learning contexts. This role can be facilitated by structures which encourage students to reflect on what they are learning, and have learnt, during and after their period of WBL (European Commission, 2013 ${ }_{[60]}$ ). An example of how this is addressed in Austria are given in Box 4.8. During their presence at the workplace, students have to reach some learning goals for every workplace learning period, and their learning is guided and assessed (Virtanen, Tynjälä and Eteläpelto, 2014 [114]). In Germany, students and supervisors in workplaces and teachers in schools use an online tool called BLoK, to record all work processes, including 20 key soft skills. Adopted nationwide in 2013, this tool was developed for apprenticeships but the model could be applied for work placements within school-based programmes. A similar approach is used in the Ontario Skills Passport, in which learners can assess and track their skills in the classroom as well as in relation to 
volunteer and extracurricular activities (Ministry of Education, 2019 [119]). In Finland, during their WBL, students have to reach some learning goals for every workplace learning period, and their learning is guided and assessed (Virtanen, Tynjälä and Eteläpelto, $\left.2014_{[114]}\right)$.

\section{Box 4.8. Encouraging students to reflect on their WBL experience in Austria}

In Austria, students in work placements maintain a work diary documenting their experience. This diary, alongside regular contact between the workplace and the education provider, helps to integrate WBL and school learning. After completing the placement the work diary is used in the school, with the outcomes of WBL evaluated after the placement or summarised in form of presentations. Trainees in Austrian VET Colleges of Tourism are briefed by teachers prior to placement beginning and later participate in systematic debriefing sessions involving a meeting between the trainee and the school teacher. The follow-up briefing is not intended as an assessment but contributes to the valorisation of what the individual has learnt whilst in the workplace. De-briefing sessions review the educational objectives of the work placement. These objectives normally specify that the student should:

- Acquire knowledge and skills relevant to his/her professional field.

- Implement skills acquired in school in a relevant work context.

- Gain comprehensive insight into the organisation of a company.

- Learn the duties and rights of an employee and check the job situation against these criteria.

- Conduct themselves in a friendly, accurate, confident and effective manner towards supervisors and co-workers.

- Gain a positive attitude both towards work in general and towards their specific professional environment.

Source: European Commission (2013[60]), Work-based Learning in Europe: Practices and Policy Pointers, http://ec.europa.eu/dgs/education_culture/repository/education/policy/vocational-policy/doc/alliance/workbased-learning-in-europe en.pdf.

\section{Policy messages}

- Accredit employers offering placements.

- Make sure that workplace supervisors are well prepared and that they provide feedback to students.

- Design measures to link school and workplace.

\section{Structuring placements}

\section{Longer work placements may bring greater benefits}

93. Work placements can be incorporated into vocational programmes in different ways. They can be understood as extensive periods of experience or as ones which are intensive. In extensive periods, students take part in work placements on regular, but 
occasional bases, often one day per week over a year or several years. Intensive work placements take place over one continuous period of time.

94. Some evidence indicates that longer, intensive work placements - a few months rather than a few weeks - bring greater benefits to students and to employers. Research in the United States suggests that longer internships are more likely to be seen as useful by students (Grasgreen, 2012 ${ }_{[120]}$ ). Longer placements allow learners to deal with more complex problems. From the employer's point of view, greater benefits may be expected from longer placements because more experienced trainees may be expected to contribute more to productive output. The theory on this last point has been extensively discussed in connection with apprenticeship [see for example (Kis, 2016 ${ }_{[89]}$; Kuczera, 2017[91])].

\section{Evidence supports the argument for longer, later placements}

95. In Sweden, an interesting study suggests that WBL of more than 20 weeks, as part of school-based VET, facilitates future recruitment and lowers its cost. Placements of longer duration will allow student time to become familiar with a workplace and to demonstrate their productive capacity. The study argues that providing training to students also increases the skills and motivation of company staff, especially for those employees who supervise students. Employers reported that students who carry out their traineeship in the third (last) year of the programme are more skilled and therefore more productive than those in earlier parts of their programme (Karlson and Persson, 2014 ${ }_{[59]}$ ). Employers might also be expected to prefer to take on older students, perceived as more mature.

\section{Arrangements for sequencing work placements are diverse}

96. Work placements often take place in the middle of a school programme and sometimes over a summer (when there is a natural break in a school-based programme). In other cases, they are broken into multiple shorter periods of placement scattered through the programme and sometimes right at the end of the programme. They may also be on a weekly basis, e.g. one half day a week (European Training Foundation, 2018 $8_{[67]}$ ). A number of competing objectives bear on the pattern. The arrangements need to be workable for employers which may, for example, find it helpful to have extra pairs of hands at particularly busy times of the year. They need to be built into the vocational programme so as to be coherent with other parts of the programme. They also need to be practical in terms of transport - it may be feasible to spend a few months with an employer in another part of the country, but not to travel there on a weekly basis (Box 4.9.). 


\section{Box 4.9. Some considerations about the sequencing of WBL}

The European Training Foundation, in a handbook, gives a few options for the sequencing of the periods in the workplace and in school:

- One day a week in the workplace on a regular basis throughout the entire programme.

- A week or more at a time in the workplace at less regular intervals: for example, one week during every school or college term.

- Equal periods in the workplace and the classroom alternating with one another.

The choice between these options will depend on a number of factors. Various questions need to be considered, including the following:

- Which combination of work-based and classroom-based learning makes the most pedagogical sense? Will it make it easier or harder for the learner to integrate theory and practice? Will it make it easier or harder for the learner to apply what has been learned in class, or to see how theory learned in the classroom relates to practice?

- What effect will the combination have on student motivation? Will there be enough practical learning at work to maintain the interest of students who are bored?

- What impact will attending classroom-based education and training have on the enterprise? Will it disrupt the ongoing work of the enterprise? Will it be a major inconvenience at peak times, such as stocktaking or harvest time? Will it mean that students will miss out on learning from work that only takes place at certain times of the business cycle or production cycle, such as stocktaking, harvest time, or before religious holidays?

- What impact will attending the workplace have on the educational institution? Will students have to miss other classes in order to attend the workplace, or can the timetable be arranged so that no work is missed? If large numbers of students are absent at the same time, will this have an impact on teachers' working arrangements?

- If the workplace time is scheduled to suit the school timetable, will this mean that the opportunity to experience and learn from important parts of the business or production cycle in the enterprise is missed?

- How should these decisions be made? By enterprises or the social partners alone? By education ministries alone? By education ministries in cooperation with the social partners? By individual schools or colleges alone? By individual enterprises alone? By individual schools and individual enterprises in cooperation?

Source: European Training Foundation (2012[56]), Work-Based Learning: Benefits and Obstacles. A Literature Review for Policy Makers and Social Partners in ETF Partner Countries, https://www.etf.europa.eu/sites/default/files/m/576199725ED683BBC1257BE8005DCF99 Workbased\%20learning Literature\%20review.pdf. 
97. Mann and Kashefpakdel $\left(2014_{[121]}\right)$ show that adults who recalled undertaking work experience at 16-19 (or at both 14-16 and at 16-19) are much more likely to agree that the placement was helpful to them in deciding on a career, getting into university, or getting a job after education than those who undertook placements aged 14-16.

\section{Work placements at the end of the vocational programme have pros and cons}

98. The timing of the work placement matters. In principle, work placements at the end of a vocational programme may allow employers to seamlessly retain the trainees that they prefer as full employees. Although part of the intent of work experience programmes is to expose students to career and life experiences not necessarily found in the school setting, students are expected to bring certain skill sets and behaviours into the workplace. Students must bring with them a level of preparation that is congruent with the setting in which they will be a part and the expectations of the employer. Well-prepared students will feel more comfortable and confident, as will the employers (Canadian Council on Learning (CCL), $\left.2009_{[118]}\right)$ ). However, there are downsides to this arrangement. In Chile, for example, graduates of four year upper secondary VET have to spend a final four months of their programme in a work placement to obtain their VET certificate. This placement is not integrated into the curriculum, quality assurance is patchy and about half of the students do not complete their workplace training and so fail to gain their qualification (Kis and Field, $\left.2009_{[122]}\right)$.

\section{Policy messages}

- Consideration should be given to offering substantive placements towards the end of the programmes, when learners are more skilled.

- Take into account that block placements are easier to organise then ones that are less intensive.

\section{Box 4.10. Summary of the chapter's policy messages}

\section{Engaging employers}

- Intermediary organisations can help support enterprises with WBL.

- Local partnerships are important to facilitate WBL.

- Schools may need support to learn how best to work with employers in developing WBL.

- Flexible arrangements are attractive for employers.

- Make sure that employers are aware of the possibilities to engage.

\section{Promoting equitable access for students}

- Take into account that some students face extra barriers and give them extra support, allowing open competition for work placements and using intermediary bodies to mediate relations between schools and employers.

- Collect data about students and their placements.

- Ensure that students who need it can receive preparation in advance of the placement, and consider options such as group placements. 


\section{Connecting learning at school and at work}

- Accredit employers offering placements.

- Make sure that workplace supervisors are well prepared and that they provide feedback to students.

- Design measures to link school and workplace.

\section{Structuring placements}

- Consideration should be given to offering substantive placements towards the end of the programmes, when learners are more skilled.

- Take into account that block placements are easier to organise then ones that are less intensive. 


\section{Annex A. Selected countries}

Based on the EU-LSF data, the aim of the annex is to look at the differences in participation in WBL of vocational and general education graduates in secondary schools, together with their employment rates, focusing on four country examples. The analysis conducted in this Annex should not be interpreted in a causal way, as the data used do not allow such conclusions. The likely presence of selection biases among the different groups of individuals prevent the identification of direct links between the participation in a specific WBL experience and the consequential estimated employment prospects. It would be ideal to further improve the collection of data on this topic to take into account baseline socio-economic and background characteristics of individuals, such as gender, and to control, at least partly, for selection biases and omitted variable ones. Granted these limitation, the data available allowed to give a snapshot of the overall trends in WBL in schools and to learn more about the differences between general education and VET graduates.

Spain

Spain is a highly decentralised country, which means that the state sets central policies and initiatives and then, the regional governments are responsible for implementing the state regulation but also for developing their own regulation at regional level. The Spanish VET system is structured around two main tracks. On the one side, there is the non-dual VET, that is the most common in terms of enrolment rate, in which students attend a two years programme with a work placement of around 300 hours. To access the Formación profesional de grado medio (intermediate level, ISCED 3), students must have the Graduado en Educación Secundaria Obligatoria (compulsory secondary school diploma) which is automatically obtained after compulsory schooling. The course lasts from 18 months to 2 years and includes a work placement of 300 hours in an enterprise (Centro de Trabajo). It leads to the diploma of Técnico, (technician). The technician diploma does not give straight access to higher education at university, but it does give access to Bachillerato (mainstream secondary education) or Higher VET (Ciclos formativos de grado superior). the work placement (in-company training module) is located at the end of the second academic year. On the other one, there is the dual VET, which represents a small, but growing, share of the student population. Dual VET has two forms: training and apprenticeship contracts and dual VET projects, implemented by the regions (SGOIFP, 2019 [116] $)$.

Focusing on school-based WBL, Panel A of Figure A.1 shows that Spain has one of the highest shares of upper secondary graduates in vocational education without any work experience $(65 \%)$. Among graduates from upper secondary vocational programmes, the most common type of working experience is the mandatory traineeship. The employment rate relative to the graduates who chose this type of SB WBL is only slightly better than the one for young individuals without any working experience, $62 \%$ versus $57 \%$ respectively. On the other hand, the group who displayed the higher employment rate is the one who engaged in a part-time independent experience $(73 \%)$.

Moving on to Panel B, it is possible to learn that, among young graduates from upper secondary general programmes, the share of individuals without any work experience is even higher, reaching the value of $87 \%$. Employment rates are, in general, consistently 
lower than the ones of vocational graduates, with a lowest of $23 \%$ for individuals who did a mandatory traineeship (which is, again, the category who scored worse in this respect), and a highest value of $55 \%$ for individuals who had a part-time independent experience.

\section{Figure A.1. Spain}

Upper secondary graduates (15-34 years-old), 2016

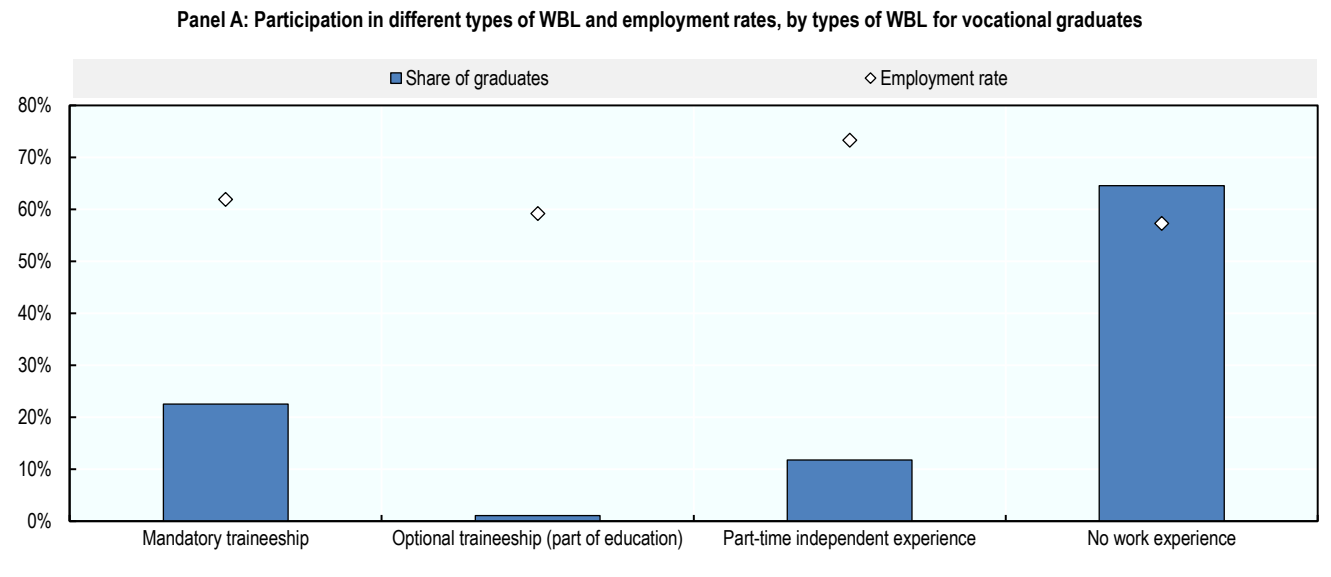

Panel B: Participation in different types of WBL and employment rates, by types of WBL for general education graduates

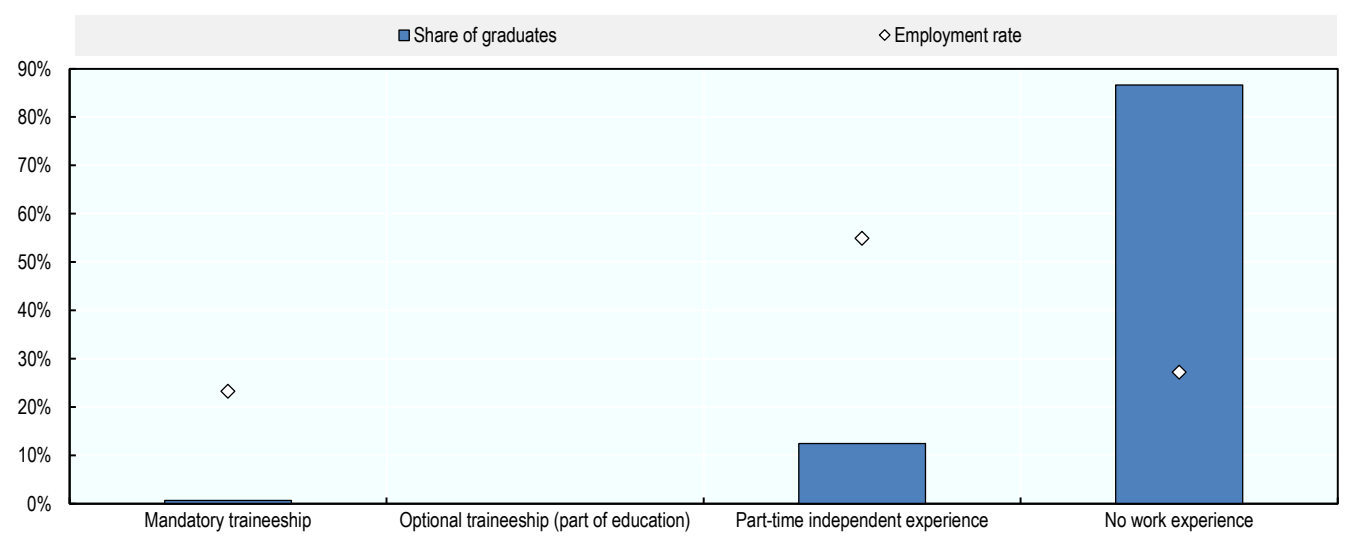

Note: The shares are computed by dividing the number of individuals in a particular category by the difference between the total population of graduates in upper secondary education and all the types of WBL that do not belong to school-based learning (namely: apprenticeships, mandatory work-based learning and missing answers). The shares should add up to one, when they does not it is due to low reliability data points that have been dropped. Moreover, it is important to underline that the data for the employment rates refer to a slightly different group of individuals than the ones for WBL shares. On the one hand, the population for the shares of WBL is the one of graduates from upper secondary education (in vocational programmes for panel A and general ones for panel B). On the other hand, the population for the employment rates is graduates in upperand post-secondary non-tertiary education (both ISCED 3 and 4). The discrepancy in the reference populations is due to the unavailability of employment rates only for ISCED 3 graduates.

Source: Eurostat $\left(2016_{[19]}\right)$, LFS ad-hoc module 2016 on young people on the labour market, https://ec.europa.eu/eurostat/web/lfs/data/database. 


\section{Norway}

In Norway, slightly more than half of the students who go into upper secondary education choose the VET educational system. Differently from Spain, apprenticeships are the most common category of WBL, as two thirds of the 15 to 34 years old graduates from upper secondary vocational education choose this type of experience.

The most common vocational education path consists in two years at school and two others of formalised apprenticeship training and work at a workplace (known as the $2+2$ model) (Haukås and Skjervheim, 2018 $8_{[123]}$ ). Panel A from Figure A.2 shows that less almost two-thirds of young upper secondary vocational graduates ${ }^{16}$ did not obtain any working experience during their course of study. As much as $25 \%$ of them opted for a working experience outside of the curriculum. Unfortunately, the share of graduates who did a mandatory traineeship is unavailable due to the low reliability of the data point.

Differently from the case of Spain, Norwegian young individuals who did a mandatory traineeship appear to benefit from a staggering $96 \%$ employment rate. It is worth noticing that employment rates are considerably high for all groups, included the one without any experience $(81 \%)$. On the other hand, Panel B shows that general education upper- and post-secondary non-tertiary ${ }^{17}$ graduates enjoy a much lower employment rate. In particular, more than half of the individuals without any experience are unemployed, while the highest value refers to those who had an independent working experience (76\%).

\footnotetext{
${ }^{16}$ Please notice that shares are computed against the sum of graduates who took part in schoolmediated WBL, those who did an independent part-time experience, and those without any experience. The total used as denominator excludes graduates who engaged in apprenticeships and mandatory work-based training. For further details, see the notes below the figure.

${ }^{17}$ For more details about the reference populations for WBL shares and employment rates, please see the notes below the figures.
} 


\section{Figure A.2. Norway}

Upper secondary graduates (15-34 years-old), 2016
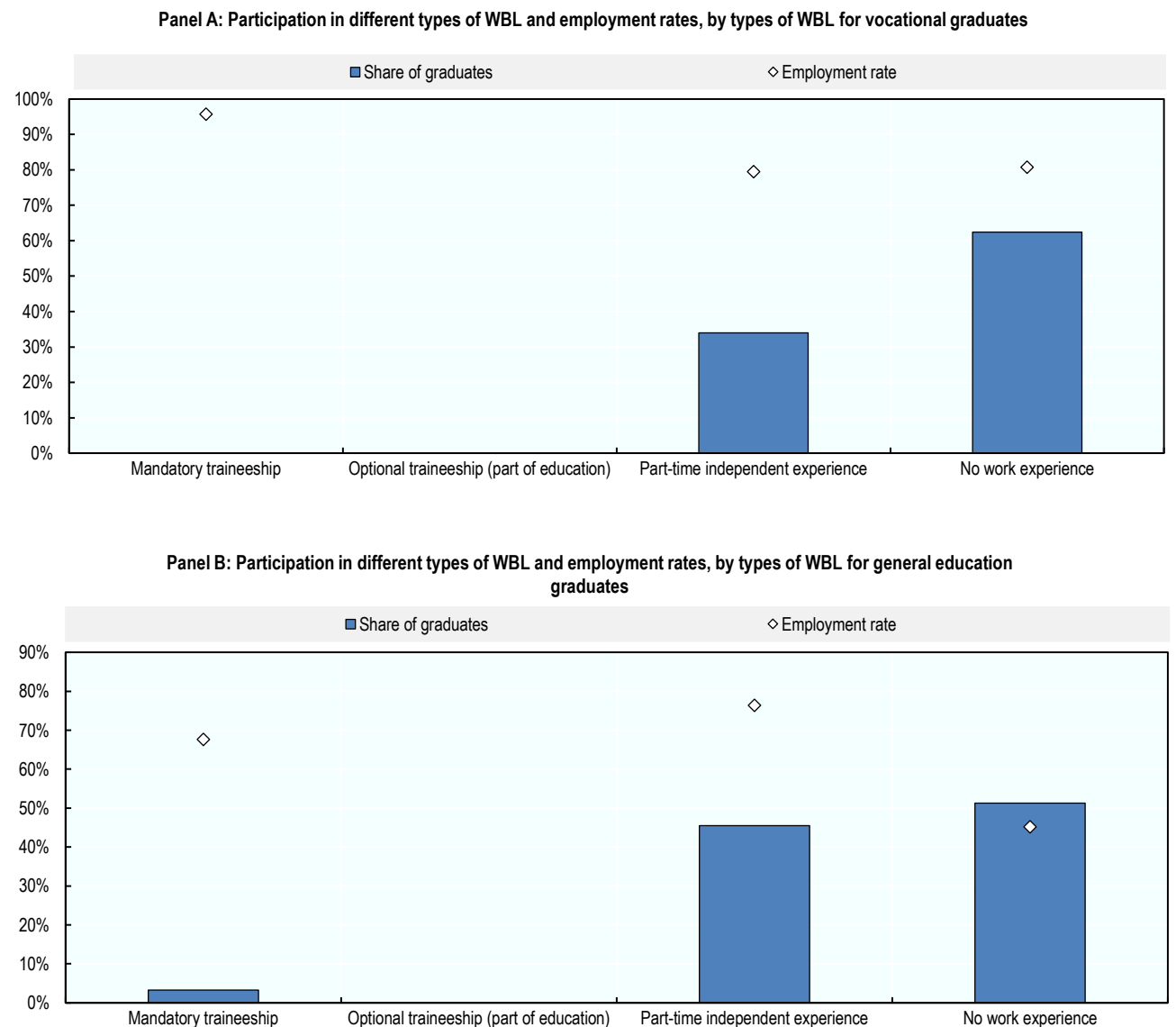

Note: The shares are computed by dividing the number of individuals in a particular category by the difference between the total population of graduates in upper secondary education and all the types of WBL that do not belong to school-based learning (namely: apprenticeships, mandatory work-based learning and missing answers). The shares should add up to one, when they does not it is due to low reliability data points that have been dropped. Moreover, it is important to underline that the data for the employment rates refer to a slightly different group of individuals than the ones for WBL shares. On the one hand, the population for the shares of WBL is the one of graduates from upper secondary education (in vocational programmes for panel A and general ones for panel B). On the other hand, the population for the employment rates is graduates in upperand post-secondary non-tertiary education (both ISCED 3 and 4). The discrepancy in the reference populations is due to the unavailability of employment rates only for ISCED 3 graduates.

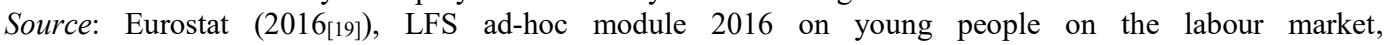
https://ec.europa.eu/eurostat/web/lfs/data/database.

\section{Finland}

Finland is characterised by one of the highest rates of young upper secondary vocational graduates who engage in school-based WBL ( $83 \%$, see Figure A.3). Interestingly, Finnish young vocational upper secondary graduates overwhelmingly opted for mandatory traineeships, with a share of $82 \%$. Graduates with such an experience fared significantly better, in terms of employment rate, than those without any experience, $76 \%$ versus $59 \%$. Nevertheless, young individuals who opted for an optional traineeship or for an 
independent part-time job scored even better with employments rates of, respectively, $82 \%$ and $79 \%$.

For what concerns the young graduates from general programmes, the share of individuals without any experience reaches $25 \%$, with a relative employment rate of $46 \%$. Moreover, Panel B of Figure A.3 further highlights that all the individuals with working experience from general education programmes opted for an extracurricular working experience.

Figure A.3. Finland

Upper secondary graduates (15-34 years-old), 2016
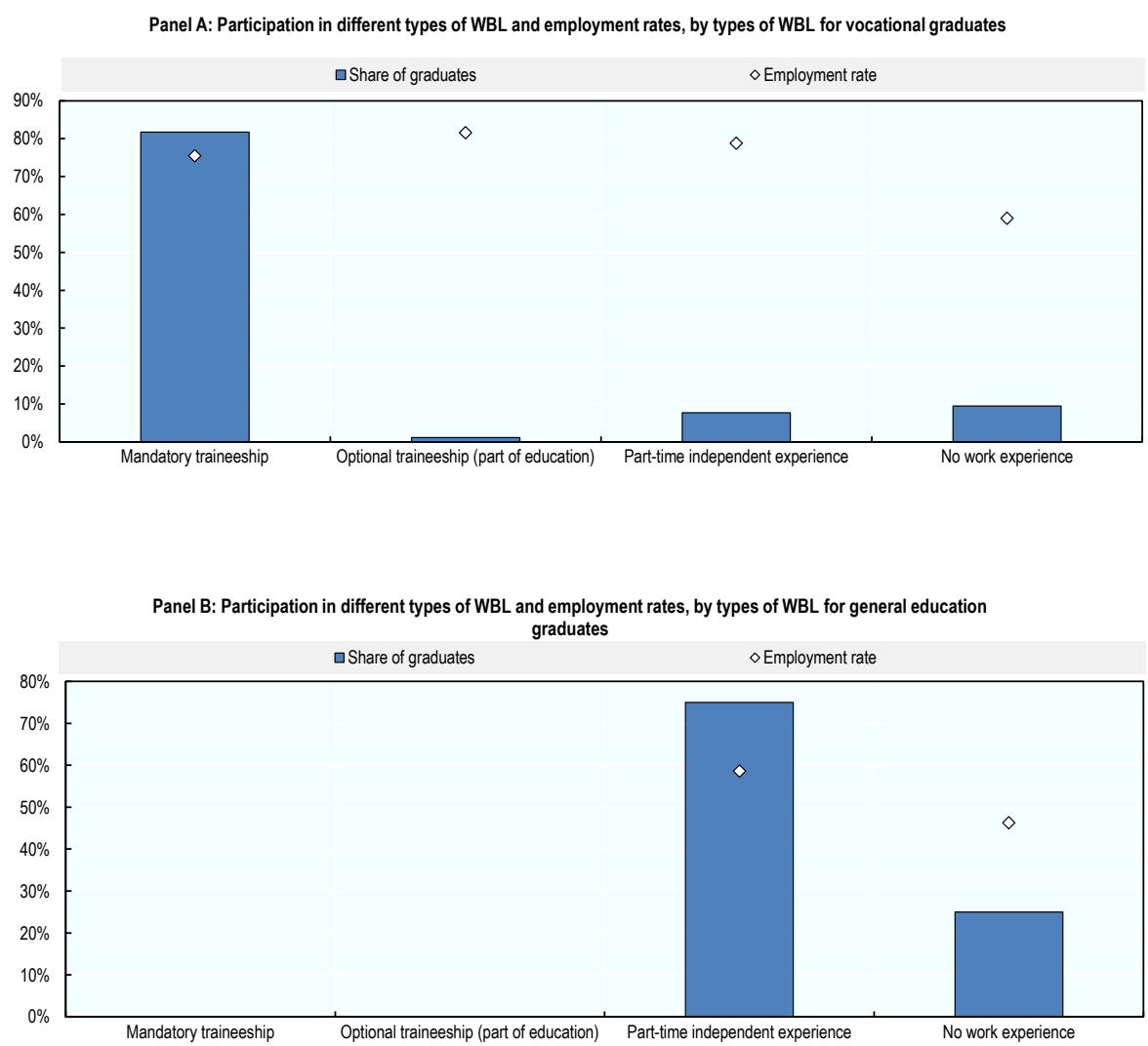

Note: The shares are computed by dividing the number of individuals in a particular category by the difference between the total population of graduates in upper secondary education and all the types of WBL that do not belong to school-based learning (namely: apprenticeships, mandatory work-based learning and missing answers). The shares should add up to one, when they does not it is due to low reliability data points that have been dropped. Moreover, it is important to underline that the data for the employment rates refer to a slightly different group of individuals than the ones for WBL shares. On the one hand, the population for the shares of WBL is the one of graduates from upper secondary education (in vocational programmes for panel A and general ones for panel B). On the other hand, the population for the employment rates is graduates in upperand post-secondary non-tertiary education (both ISCED 3 and 4). The discrepancy in the reference populations is due to the unavailability of employment rates only for ISCED 3 graduates.

Source: Eurostat (2016[19]), LFS ad-hoc module 2016 on young people on the labour market, https://ec.europa.eu/eurostat/web/lfs/data/database. 


\section{The Netherlands}

The Netherlands present a relatively high level of graduates who achieved some kind of work experience while studying, as only $15 \%$ of graduates from a vocational programme and $22 \%$ of those from a general one did not achieve any experience while studying (Figure A.4).

Three fourths of the students in vocational education engage in the school track, while one fourth opt for the apprenticeship one. The latter is preferred by older students (older than 30 ) while the former usually is the choice of younger ones. Both of them dedicates a substantial part of the programme to WBL, at least $20 \%$ for the school-based ones, and at least $60 \%$ for dual tracks (apprenticeships ones) (Cedefop, 2018 [124] $_{\text {). }}$.

Similarly to the cases analysed previously, the employment rate for upper- and postsecondary non-tertiary graduates ${ }^{18}$ in vocational tracks benefit from a generally higher employment rate across all groups (Figure A.4).

Among graduates from vocational programmes, the most preferred choice appears to be the mandatory traineeship, with a share of $47 \%$. By contrast, among graduates from general education programmes, the most common type of working experience is an independent part-time one, with $51 \%$. However, employment rates follow the same pattern as for vocational graduates, with the highest value for those who did an optional traineeship and the lowest one (among those who had some kind of experience) for the group who did a mandatory traineeship.

\footnotetext{
${ }^{18}$ For more details about the reference populations for WBL shares and employment rates, please
} see the notes below the figures. 


\section{Figure A.4. The Netherlands}

Upper secondary graduates (15-34 years-old), 2016

Panel A: Participation in different types of WBL and employment rates, by types of WBL for vocational graduates
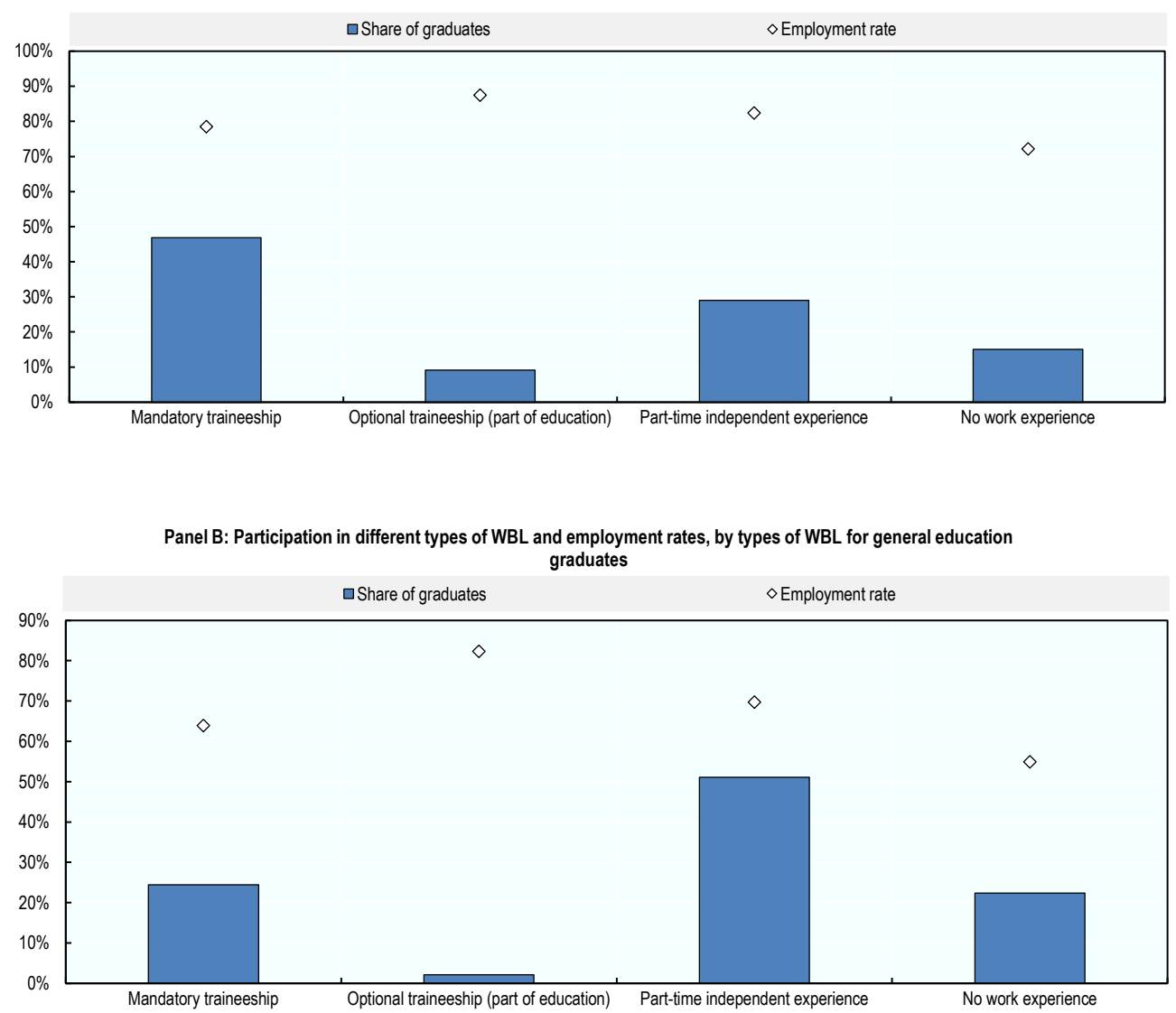

Note: The shares are computed by dividing the number of individuals in a particular category by the difference between the total population of graduates in upper secondary education and all the types of WBL that do not belong to school-based learning (namely: apprenticeships, mandatory work-based learning and missing answers). The shares should add up to one, when they does not it is due to low reliability data points that have been dropped. Moreover, it is important to underline that the data for the employment rates refer to a slightly different group of individuals than the ones for WBL shares. On the one hand, the population for the shares of WBL is the one of graduates from upper secondary education (in vocational programmes for panel A and general ones for panel B). On the other hand, the population for the employment rates is graduates in upperand post-secondary non-tertiary education (both ISCED 3 and 4). The discrepancy in the reference populations is due to the unavailability of employment rates only for ISCED 3 graduates.

Source: Eurostat $\left(2016_{[19]}\right)$, LFS ad-hoc module 2016 on young people on the labour market, https://ec.europa.eu/eurostat/web/lfs/data/database. 


\section{References}

Aarkrog, V. (2019), “The Interrelation of General Education and VET: Understandings, Functions and Pedagogy", in The Wiley Handbook of Vocational Education and Training, John Wiley \& Sons, Inc, https://doi.org/10.1002/9781119098713.ch14.

Aarkrog, V. (2005), "Learning in the workplace and the significance of school-based education: A study of learning in a Danish vocational education and training programme", Lifelong Education, Vol. 24/2, pp. 137-147.

ACT (2018), Answer to the OECD Questionnaire on WBL in schools.

Andersen, O. and K. Kruse (2016), Vocational education and training in Europe - Denmark, http://www.cedefop.europa.eu/en/publications-and-resources/country-reports/denmark-vet-europecountry-report-2016.

Anlezark, A. and P. Lim (2011), Does Combining School and Work Affect School and Post-school Outcomes?, NCVER, Adelaide, https://www.ncver.edu.au/_data/assets/file/0018/5922/lsay_2398.pdf.

Archer, L., J. Dewitt and J. Osborne (2015), “Is science for us? Black students' and parents' views of science and science careers", Science Education, Vol. 99/2, pp. 199-237, http://dx.doi.org/10.1002/sce.21146.

Arum, R. and S. Way (2004), "School-community relationships and the early labour market: outcomes of sub-baccaulaureat students", in After the Bell - Family Background and Educational Success, Routledge.

Becquet, V. (2013), “《 Jeunes des quartiers difficiles » en service civique : du ciblage politique d'un public aux usages juvéniles”, Lien social et Politiques, Vol. 70, p. 119, http://dx.doi.org/10.7202/1021159ar.

Bergseng, B. (2019), Vocational Education and Training in Bulgaria: Governance and Funding, OECD Reviews of Vocational Education and Training, OECD Publishing, Paris, https://dx.doi.org/10.1787/25bad018-en.

Bergseng, B., E. Degler and S. Lüthi (2019), Unlocking the Potential of Migrants in Germany, OECD Reviews of Vocational Education and Training, OECD Publishing, Paris, https://doi.org/10.1787/82ccc2a3-en.

Billett, S. (2006), Informing Post-school Pathways: Investigating School Students' Authentic Work Experiences, NCVER, Adelaide.

Blasko, Z., B. Little and A. Woodley (2002), UK Graduates and the Impact of Work Experience, Centre for Higher Education Research and Information, London, https://dera.ioe.ac.uk/5171/1/rd17_02.pdf.

Blossfeld, H. et al. (2016), Models of Secondary Education and Social Inequality, Edward Elgar Publishing, http://dx.doi.org/10.4337/9781785367267. 
Blossfled, H. et al. (eds.) (2016), Reproduction of inequality in educational attainment through curricular differentiation in secondary school - A case study of the USA, Edward Elgar Publishing, http://dx.doi.org/10.4337/9781785367267.00026.

Canadian Council on Learning (CCL) (2009), The Effectiveness of Work-experience Programs in Canadian High Schools, Canadian Council on Learning, Ottawa.

Cedefop (2018), Apprenticeship Schemes in European Countries. A Cross-nation Overview, Publications Office of the European Union, Luxembourg, http://data.europa.eu/doi/10.2801/722857.

Cedefop (2018), Developments in vocational education and training policy in 2015-2017: the Netherlands, http://www.cedefop.europa.eu/en/publications-and-resources/country-reports/vet-policy-developmentsthe-netherlands.

Chankseliani, M., E. Keep and S. Wilde (2017), People and Policy: A Comparative Study of Apprenticeship Across Eight National Contexts, WISE, University of Oxford.

CSFO (2016), QualiCarte, http://www.berufsbildung.ch/dyn/bin/7361-7626-1-qualicarte_fr_2016i.pdf.

Cuadra, E. and J. Moreno (2005), Responding to the Twin Challenges: Teachers, Teaching and Technology, World Bank, Washington DC.

Deming, D. (2015), The Growing Importance of Social Skills in the Labor Market, National Bureau of Economic Research, Cambridge, MA, http://dx.doi.org/10.3386/w21473.

Department for Education (2019), 16 to 19 study programmes: guidance (2018 to 2019 academic year), https://www.gov.uk/government/publications/16-to-19-study-programmes-guide-for-providers/16-to19-study-programmes-guidance-2018-to-2019-academic-year.

Elsevier (ed.) (2006), "Working while enrolled in a university: does it pay?", Labour Economics, Vol. vol. 13(2), pages 167-189, April.

Equal Opportunities Commission (2005), “Gender equality in work experience placements for young people”, EOC Working Paper Series, No. 27, Equal Opportunities Commission, Manchester.

European Commission (2013), Workbased Learning in Europe: Practices and Policy Pointers, European Commission, http://ec.europa.eu/dgs/education culture/repository/education/policy/vocationalpolicy/doc/alliance/work-based-learning-in-europe en.pdf.

European Training Foundation (2018), Work-based Learning: How Ready Are We?, European Training Foundation, https://www.etf.europa.eu/sites/default/files/2018-09/Work-based\%20learning_Tool.pdf.

European Training Foundation (2012), Work-Based Learning: Benefits and Obstacles. A Literature Review for Policy Makers and Social Partners in ETF Partner Countries, European Training Foundation, https://www.etf.europa.eu/sites/default/files/m/576199725ED683BBC1257BE8005DCF99 Workbased\%20learning_Literature\%20review.pdf.

European Union (2016), Education and Training Monitor 2016, Directorate-General for Education and Culture.

Eurostat (2019), Employment and unemployment (LFS) - Overview, https://ec.europa.eu/eurostat/web/lfs/overview. 
Eurostat (2016), LFS ad hoc modules - Young people on the labor market, https://ec.europa.eu/eurostat/web/lfs/data/database.

Fazekas, M. and S. Field (2013), A Skills beyond School Review of Switzerland, OECD Reviews of Vocational Education and Training, OECD Publishing, Paris, https://dx.doi.org/10.1787/9789264062665-en.

Field, S. and A. Guez (2018), Pathways of Progression : Linking Technical and Vocational Education and Training with Post-secondary Education, UNESCO, Paris, http://www.unesco.org/new/fileadmin/MULTIMEDIA/FIELD/Beirut/images/Education/LinkingTVET HED.pdf.

Field, S., V. Kis and M. Kuczera (2012), A Skills beyond School Commentary on Spain, OECD Reviews of Vocational Education and Training, OECD Publishing, Paris, http://www.oecd.org/education/skillsbeyond-school/OECD $\% 20$ Reviews $\% 20$ of $\% 20$ Vocational $\% 20$ Education $\% 20$ and $\% 20$ Training $\% 20$ $\% 20 \mathrm{~A} \% 20$ Skills $\% 20$ Beyond $\% 20$ School $\% 20$ Commentary $\% 20$ on $\% 20$ Spain.pdf.

Flynn, M., H. Pillay and J. Watters (2014), "Industry-school partnerships: boundary crossing to enable school to work transitions", Journal of Education and Work, Vol. 29/3, pp. 309-331, http://dx.doi.org/10.1080/13639080.2014.934789.

Francis, B. et al. (2005), Gender Equality in Work Experience Placements for Young People, Equal Opportunities Commission.

GOV.UK (2019), Guidance - Industry placements, https://www.gov.uk/guidance/industry-placements.

Grasgreen, A. (2012), "Internships for all”, Inside Higher Ed, http://www.insidehighered.com/news/2012/10/11/pitt-johnson-wales-make-big-internship-promises.

Grasgreen, A. (2012), "Resume-builder or rip-off”, Inside Higher Ed. February, 2012, http://www.insidehighered.com/news/2012/02/03/growth-short-term-internships-over-academicbreaks.

Guidance, I. (ed.) (2003), Differences in Career Attitude and Career Knowledge for High School Students with and without Paid Work Experience, https://link.springer.com/article/10.1023/A:1022674528730.

Hanushek, E., L. Woessmann and L. Zhang (2011), "General education, vocational education, and labormarket outcomes over the lifecycle”, Journal of Human Resources, Vol. 52/1, pp. 48-87, http://www.nber.org/papers/w17504.

Haukås, M. and K. Skjervheim (2018), Vocational Education and Training in Europe - Norway, Cedefop ReferNet VET in Europe Reports, Cedefop, http://libserver.cedefop.europa.eu/vetelib/2018/ReferNet_Austria\%20_VET in_Europe 2018.pdf.

Health and Safety Executive (2019), Work experience, http://www.hse.gov.uk/youngpeople/workexperience/index.htm.

Heckman, J. and T. Kautz (2012), "Hard evidence on soft skills", Labour Economics, Vol. 19/4, pp. 451464, http://dx.doi.org/10.1016/j.labeco.2012.05.014.

Helms Jørgensen, C. (2014), The Current State of the Challenges for VET in Denmark, Nord-VET - The future of VET in the Nordic Countries, Roskilde University, http://nordvet.dk/indhold/uploads/reportlb_dk.pdf. 
Hensvik, L., D. Müller and O. Nordström Skans (2017), “Connecting the young: High school graduates' matching to first jobs in booms and great recessions”, IFAU Working Paper, No. 2017:2.

Hodge, S. et al. (2017), The Contribution of VET Student Placement to Innovation in Host Organisations, NCVER, Adelaide, https://files.eric.ed.gov/fulltext/ED575679.pdf.

Hodgkinson, L. and L. Hamill (2010), "Pre-16 school work experience and civil engineering careers", Proceedings of the Institution of Civil Engineers - Civil Engineering, Vol. 163/3, pp. 131-136, http://dx.doi.org/10.1680/cien.2010.163.3.131.

Hoftijzer, M., P. Stronkowski and J. Rozenbaum (2018), Getting Out of School and into the Workplace: Strengthening Work-Based Learning in Upper Secondary Technical Education in Poland's Swietokrzyskie Region, The World Bank, http://dx.doi.org/10.1596/978-1-4648-1322-1.

Hooley, T., A. Watts and D. Andrews (2015), Teachers and Careers: The Role Of School Teachers in Delivering Career and Employability Learning, International Centre for Guidance Studies, University of Derby, https://derby.openrepository.com/handle/10545/346008.

Hora, M., M. Wolfgram and S. Thompson (2017), "What do we know about the impact of internships on student outcomes? Results from a preliminary review of the scholarly and practitioner literatures", CCWT Research Brief, No. 2, http://ccwt.wceruw.org/documents/CCWT-report-Designing-InternshipPrograms.pdf.

Industry Training Federation (2019), Industry Training Federation website, https://www.itf.org.nz/ (accessed on 29 July 2019).

Interagency Group on Technical and Vocational Education and Training (2016), Investing in Work-Based Learning, https://www.ilo.org/wcmsp5/groups/public/---ed_emp/--ifp_skills/documents/publication/wcms 565923.pdf.

Jacobson, J. and L. Shade (2018), “Stringtern: springboarding or stringing along young interns' careers?”, Journal of Education and Work, Vol. 31/3, pp. 320-337, http://dx.doi.org/10.1080/13639080.2018.1473559.

Jeon, S. (2019), Unlocking the Potential of Migrants: Cross-country Analysis, OECD Reviews of Vocational Education and Training, OECD Publishing, Paris, https://doi.org/10.1787/045be9b0-en.

Joensen, J. (2009), “Academic and labour market success: The impact of student employment, abilities, and preferences”, Working Article No. 1352077, 27 April. Stockholm: Social Science Research Network (SSRN).

Johnston, K. et al. (2014), "Enacting key skills-based curricula in secondary education: lessons from a technology-mediated, group-based learning initiative", Technology, Pedagogy and Education, Vol. 24/4, pp. 423-442, http://dx.doi.org/10.1080/1475939x.2014.890641.

Jørgensen, C. (2012), Recent Innovations in VET in Denmark. Responses to Key Challenges for VET, http://nord-vet.dk/indhold/uploads/reportlc_dk.pdf.

Karlson, N. and K. Persson (2014), "Effects of work-based learning on companies involved in VET education”, Ratio Working Paper, No. 258, http://ratio.se/app/uploads/2015/09/nk_kp_work_based_learning_258.pdf.

Kemple, J. and J. Snipes (2000), Career Academies: Impacts on Students' Engagement and Performance in High School, http://ies.ed.gov/ncee/wwc/study/78544. 
Kis, V. (2016), "Work, train, win: work-based learning design and management for productivity gains", OECD Education Working Papers, No. 135, OECD Publishing, Paris, https://dx.doi.org/10.1787/5jlz6rbns1g1-en.

Kis, V. (2016), "Work-based learning for youth at risk: Getting employers on board", OECD Education Working Papers, No. 150, OECD Publishing, Paris, https://dx.doi.org/10.1787/5e122a91-en.

Kis, V. and S. Field (2009), Learning for Jobs. Chile: A First Report, The OECD Review of Vocational Education and Training. OECD Publishing, Paris, http://www.oecd.org/dataoecd/33/13/44167258.pd.

Klein, M., C. Iannelli and E. Smyth (2016), School Subject Choices and Social Class Differences in Entry to Higher Education - Comparing Scotland and Ireland, Edward Elgar Publishing, http://dx.doi.org/10.4337/9781785367267.00025.

Kuczera, M. (2017), “Incentives for apprenticeship”, OECD Education Working Papers, No. 152, OECD Publishing, Paris, https://dx.doi.org/10.1787/55bb556d-en.

Kuczera, M. (2017), "Striking the right balance Costs and benefits of apprenticeship", OECD Education Working Papers, No. 153, OECD Publishing, Paris, https://doi.org/10.1787/19939019.

Kuczera, M., T. Bastianić and S. Field (2018), Apprenticeship and Vocational Education and Training in Israel, OECD Reviews of Vocational Education and Training, OECD Publishing, Paris, https://dx.doi.org/10.1787/9789264302051-en.

Kuczera, M. and S. Jeon (2019), Vocational Education and Training in Sweden, OECD Reviews of Vocational Education and Training, OECD Publishing, Paris, https://doi.org/10.1787/g2g9fac5-en.

Lasonen, J. (2005), Workplaces as Learning Environments: Assessments by Young People After Transition from School to Work, http://www.bwpat.de/7eu/lasonen_fi_bwpat7.pdf.

Le Gallais, T. and R. Hatcher (2014), "How school work experience policies can widen student horizons or reproduce social inequality", in Understanding Employer Engagement in Education: Theories and Evidence, Taylor and Francis.

Leid Commission (2018), Upper secondary education in Norway.

Loveless, T. (2013), How Well are American Students Learning?, Brookings Institution, Washington, DC, https://www.brookings.edu/wp-content/uploads/2016/03/Brown-Center-Report-2016.pdf.

Maisto, C. and F. Pastore (2017), "Alternanza scuola-lavoro: un bilancio preliminare a un anno dall'attuazione", Economia \& lavoro, Rivista di politica sindacale, sociologia e relazioni industriali, Vol. 1, pp. 133-146, http://dx.doi.org/10.7384/87127.

Mamun, A. et al. (2017), "Impact of early work experiences on subsequent paid employment for young adults with disabilities", Career Development and Transition for Exceptional Individuals, Vol. 41/4, pp. 212-222, http://dx.doi.org/10.1177/2165143417726302.

Mann, A. and J. Dawkins (2014), Employer Engagement in Education: Literature Review, CfBT Education Trust, https://www.educationandemployers.org/wp-content/uploads/2014/06/r-employerengagement-literature-review-2014.pdf.

Mann, A. and E. Kashefpakdel (2014), "The views of young Britons (aged 19-24) on their teenage experiences of school-mediated employer engagement", in Understanding Employer Engagement in Education: Theories and Evidence, Taylor and Francis. 
Ministry of Education (2019), The Ontario Skills Passport, http://www.skills.edu.gov.on.ca/OSP2Web/EDU/Welcome.xhtml.

Ministry of Education (2018), Review of VET in Sweden. Background Report.

Ministry of Education (2016), Students on Work Experience - A Health and Safety guide for Schools and Employers, Ministry of Education, https://www.education.govt.nz/assets/Uploads/SES-Students-onWork-Experience-HS.PDF.

Musset, P. (2014), A Skills beyond School Commentary on Romania, OECD Reviews of Vocational Education and Training, OECD Publishing, Paris, http://www.oecd.org/education/skills-beyondschool/ASkillsBeyondSchoolCommentaryOnRomania.pdf.

Musset, P. (forthcoming), Note on Australia - Improving WBL in schools.

Musset, P. and L. Mytna Kurekova (2018), "Working it out: Career guidance and employer engagement", OECD Education Working Papers, No. 175, OECD Publishing, Paris, https://dx.doi.org/10.1787/51c9d18d-en.

National Agency for Education (2018), Answers to OECD Questionnaire from Sweden.

National Catholic Education Commission (2018), Answer of NCEC to the OECD Questionnaire on WBL in schools in Australia.

Nedelkoska, L. and G. Quintini (2018), “Automation, skills use and training”, OECD Social, Employment and Migration Working Papers, No. 202, OECD Publishing, Paris, https://dx.doi.org/10.1787/2e2f4eea-en.

Neumark, D. and D. Rothstein (2005), Do School-To-Work Programs Help the "Forgotten Half"?, National Bureau of Economic Research, Cambridge, MA, http://dx.doi.org/10.3386/w11636.

Neyt, B. et al. (2018), "Does student work really affect educational outcomes? A review of the literature", Journal of Economic Surveys, Vol. 33/3, pp. 896-921, http://dx.doi.org/10.1111/joes.12301.

O'Donnell, S. (2018), Upper Secondary Education in Nine Jurisdictions, National Council for Curriculum and Assessment (NCCA), https://www.ncca.ie/media/3337/scoping-report-online-2.pdf.

OECD (2019), Education at a Glance 2018: Educational attainment and Labor-force status, OECD Publishing, Paris, http://dx.doi.org/10.1787/0b8f90e9-en.

OECD (2019), OECD.Stat, https://stats.oecd.org/\#.

OECD (2019), Transition from school to work. Indicator on the share of population by education and labour force status, https://stats.oecd.org/Index.aspx?DataSetCode=EAG TRANS\#.

OECD (2018), Education at a Glance 2018: OECD Indicators, OECD Publishing, Paris, https://dx.doi.org/10.1787/eag-2018-en.

OECD (2018), Education Policy Outlook 2018: Putting Student Learning at the Centre, OECD Publishing, Paris, https://dx.doi.org/10.1787/9789264301528-en. 
OECD (2018), OECD Handbook for Internationally Comparative Education Statistics 2018: Concepts, Standards, Definitions and Classifications, OECD Publishing, Paris, https://dx.doi.org/10.1787/9789264304444-en.

OECD (2018), Responsive School Systems: Connecting Facilities, Sectors and Programmes for Student Success, OECD Reviews of School Resources, OECD Publishing, Paris, https://dx.doi.org/10.1787/9789264306707-en.

OECD (2018), Seven Questions about Apprenticeships: Answers from International Experience, OECD Reviews of Vocational Education and Training, OECD Publishing, Paris, https://dx.doi.org/10.1787/9789264306486-en.

OECD (2016), Netherlands 2016: Foundations for the Future, Reviews of National Policies for Education, OECD Publishing, Paris, https://dx.doi.org/10.1787/9789264257658-en.

OECD (2015), OECD Employment Outlook 2015, OECD Publishing, Paris, https://dx.doi.org/10.1787/empl_outlook-2015-en.

OECD (2014), Skills beyond School: Synthesis Report, OECD Reviews of Vocational Education and Training, OECD Publishing, Paris, https://dx.doi.org/10.1787/9789264214682-en.

OECD (2012), Equity and Quality in Education: Supporting Disadvantaged Students and Schools, OECD Publishing, Paris, https://dx.doi.org/10.1787/9789264130852-en.

OECD (2012), PISA 2012 (database), https://www.oecd.org/pisa/data/pisa2012databasedownloadabledata.htm.

OECD (2010), Learning for Jobs, OECD Reviews of Vocational Education and Training, OECD Publishing, Paris, https://dx.doi.org/10.1787/9789264087460-en.

O’Higgins, N. and L. Pinedo (2018), "Interns and outcomes: Just how effective are internships as a bridge to stable employment?”, ILO Working Paper, No. 241, International Labour Office, https://www.ilo.org/wcmsp5/groups/public/---ed_emp/documents/publication/wcms_637362.pdf.

Osgood, J., B. Francis and L. Archer (2006), “Gendered identities and work placement: why don't boys care?", Journal of Education Policy, Vol. 21/3, pp. 305-321, http://dx.doi.org/10.1080/02680930600600424.

Paparella, D. and L. Savino (2008), "Pathways to work: Current practices and future needs for the labour market integration of young people - Young in occupations and unemployment: Thinking of their better integration in the labour market".

Partnership-Project on Work-based Learning and Teaching (2015), School-to-work Transition in Europe and the Approach to Work-based Training, http://www.workbasedtraining.eu/wpcontent/uploads/2015/12/OVERVIEW final.pdf.

Pastore, F. (2017), "Why So Slow? The School-to-Work Transition in Italy", IZA Discussion Paper, No. 10767, http://ftp.iza.org/dp10767.pdf.

Percy, C. (2010), NEET status during sixth form years vs. part-time paid work in years 9, 10 and 11 -an initial statistical analysis using the LSYPE, Paper presented to the Education and Employers Taskforce Conference, The point of partnership: understanding employer engagement in education, 15 October 2010, https://www.educationandemployers.org/wpcontent/uploads/2014/06/ks4 employment and_ks5 outcomes_chris-percy.pdf. 
Pew Research Centre (2018), The share of teens with summer jobs has plunged since 2000, and the type of work they do has shifted, https://www.pewresearch.org/fact-tank/2018/07/02/the-share-of-teens-withsummer-jobs-has-plunged-since-2000-and-the-type-of-work-they-do-has-shifted/.

Polesel, J. et al. (2016), "Understanding the nature of school partnerships with business in delivery of vocational programmes in schools in Australia", Journal of Education and Work, Vol. 30/3, pp. 283298, http://dx.doi.org/10.1080/13639080.2016.1165344.

Polidano, C. and D. Tabasso (2014), "Making it real: The benefits of workplace learning in uppersecondary vocational education and training courses", Economics of Education Review, Vol. 42, pp. 130-146, http://dx.doi.org/10.1016/j.econedurev.2014.06.003.

Quintini, G., J. Martin and S. Martin (2007), "The Changing Nature of the School-to-Work Transition Process in OECD Countries", IZA Discussion Paper No. 2582. IZA, http://www.oecd.org/employment/emp/38187773.pdf.

Robert, P. and E. Saar (2012), “Learning and Working: The Impact of the 'Double Status Position' on the Labour Market Entry Process of Graduates in CEE Countries", European Sociological Review, Vol. 28/6, pp. 742-754, http://dx.doi.org/10.1093/esr/jcr091.

Robinson, L. (1999), The Effects of Part-time Work on School Students, Australian Council for Educational Research, https://research.acer.edu.au/cgi/viewcontent.cgi?article=1017\&context=lsay research.

Sahlberg, P. (2007), Secondary Education in OECD Countries: Common Challenges, Differing Solutions, European Training Foundation, https://www.etf.europa.eu/sites/default/files/m/C12578310056925BC12573850034415B NOTE78HD 6G.pdf.

Sattar, S. (2010), Evidence Scan of Work Experience Programs, Mathematica Reference Number: $06747-$ 100, Mathematica Policy Research, Inc, http://eric.ed.gov/?id=ED510450.

SGOIFP (2019), Answer from Spain to OECD on WBL in Schools.

Shanahan, M. and B. Flaherty (2001), "Dynamic Patterns of Time Use in Adolescence", Child Development, Vol. 72/2, pp. 385-401, http://dx.doi.org/10.1111/1467-8624.00285.

Skolverket and Refernet Sweden (2016), Vocational Education and Training in Europe - Sweden, https://cumulus.cedefop.europa.eu/files/vetelib/2016/2016_CR_SE.pdf.

Smith, C., S. Ferns and L. Russell (2014), The Impact of Work Integrated Learning on Student Workreadiness: Final Report, Curtin University of Technology, LSN Teaching Development Unit.

Smith, E. and R. Harris (2000), Work Placements in Vocational Education and Training Courses: Evidence from the Cross-sectoral Literature. Review of Research, National Centre for Vocational Education Research, https://eric.ed.gov/?id=ED454393.

Smith, P., J. Dalton and R. Dolheguy (2004), "Student experiences of work placement in school-based vocational programs", Education + Training, Vol. 46/5, pp. 262-268, http://dx.doi.org/10.1108/00400910410549841.

Staff, J. and J. Mortimer (2007), "Educational and Work Strategies from Adolescence to Early Adulthood: Consequences for Educational Attainment", Social Forces, Vol. 85/3, pp. 1169-1194, http://dx.doi.org/10.1353/sof.2007.0057. 
StageMarket (2019), stagemarket.nl, https://www.stagemarkt.nl/Zoeken/.

Sund, K. (2013), “Detracking Swedish compulsory schools: Any losers, any winners?", Empirical Economics, Vol. Vol. 44/2, pp. pp. 899-920.

Sweet, R. (2013), Work-based learning: Why? How?.

Symonds, J. and C. O'Sullivan (2017), "Educating young adults to be work-ready in Ireland and the United Kingdom: A review of programmes and outcomes", Review of Education, Vol. 5/3, pp. 229263, http://dx.doi.org/10.1002/rev3.3099.

UK Commission for Employment and Skills (2015), Catch 16-24: Youth employment challenge, https://www.gov.uk/government/publications/catch-16-24-youth-employment-challenge.

UK Government (2015), Policy Paper. 2010 to 2015 Government Policy: Young People, UK Government, https://www.gov.uk/government/publications/2010-to-2015-government-policy-young-people/2010-to2015-government-policy-young-people\#appendix-3-raising-the-participation-age.

UKCES (2015), "Catch 16-24", https://assets.publishing.service.gov.uk/government/uploads/system/uploads/attachment_data/file/4049 97/15.02.18. Youth_report_V17.pdf.

UKCES (2015), Employer Skills Survey 2015 of 91000 Employers, UKCES, London.

UKCES (2015), The Death of the Saturday Job, https://assets.publishing.service.gov.uk/government/uploads/system/uploads/attachment_data/file/4352 85/15.06.15. DOTSJ Report design final EDIT.pdf.

Vickers, M., S. Lamb and J. Hinkley (2003), Student Workers in High School and Beyond: The Effects of Part-Time Employment on Participation in Education, Training and Work, Australian Council for Educational Research.

Virtanen, A., P. Tynjälä and A. Eteläpelto (2014), "Factors promoting vocational students' learning at work: study on student experiences", Journal of Education and Work, Vol. 27/1, pp. 43-70, http://dx.doi.org/10.1080/13639080.2012.718748.

Woerkom, M., W. Nijhof and L. Nieuwenhuis (2002), “Critical Reflective Working Behaviour: A Survey of Research", Journal of European Industrial Training, Vol. 26/8, pp. 375-383. 